UNIVERSIDADE DE SÃO PAULO

ESCOLA DE ENGENHARIA DE SÃO CARLOS

INSTITUTO DE FÍSICA DE SÃO CARLOS

INSTITUTO DE QUIMICA DE SÃO CARLOS

\title{
"AVALIAÇÃO MICROESTRUTURAL E DAS PROPRIEDADES MECÂNICAS DE AÇO ARBL DE RESISTÊNCIA AMBIENTAL SOLDADO A ARCO SUBMERSO COM ADIÇÃO DE PÓ METÁLICO"
}

\author{
Eng $^{\circ}$ M. Sc. Gil Eduardo Guimarães
}

Tese apresentada à Área Interunidades - Ciência e

Engenharia de Materiais - da Universidade de São Paulo, como parte dos requisitos para a obtenção do título de Doutor em Ciência e Engenharia de Materiais

ORIENTADOR: Prof. Assoc. Samuel Irati Novaes Gomes

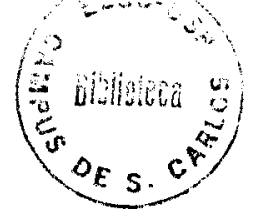

SÃO CARLOS

1999 


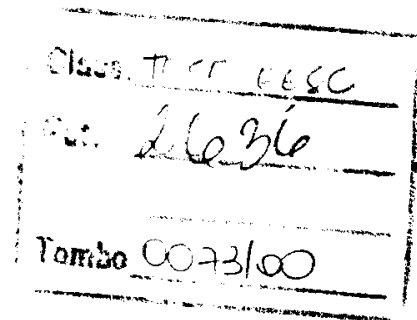

$+2: 3$

Ficha catalográfica preparada pela Seção de Tratamento da Informação do Serviço de Biblioteca - EESC/USP

Guimarães, Gil Eduardo

Avaliaçāo microestrutural e das propriedades mecânicas

G963a de aço ARBL de resistência ambiental soldado a arco submerso com adição de pó metálico / Gil Eduardo Guimarães. -- são Carlos, 2000.

Tese (Doutorado) -- Escola de Engenharia de são Carlos/Instituto de Física de são Carlos/Instituto de Química de São Carlos-Universidade de São Paulo, 2000. Área Interunidades: Ciência e Engenharia de Materiais.

Orientador: Prof. Dr. Samuel Irati Novaes Gomes.

1. Soldagem arco submerso. 2. Adição de pó metálico. I. Título. 
UNIVERSIDADE DE SÃO PAULO

Ciência e Engenharia de Materiais

Caixa Postal 369 - CEP 13560-970 - São Carlos-SP - Brasil

Tel: (0xx16) 2739589/ Fax: (0xx16) 2739777

E-mail: erica@if.sc.usp.br

MEMBROS DA COMISSÃO JULGADORA DA TESE DE DOUTORADO DE GIL EDUARDO GUIMARÃES, APRESENTADA A ÁREA INTERUNIDADES EM CIÊNCIA E ENGENHARIA DE MATERIAIS, DA EESC-IFSC-IQSC, UNIVERSIDADE DE SÃO PAULO, EM 27/10/1999.

COMISSÃO JULGADORA:
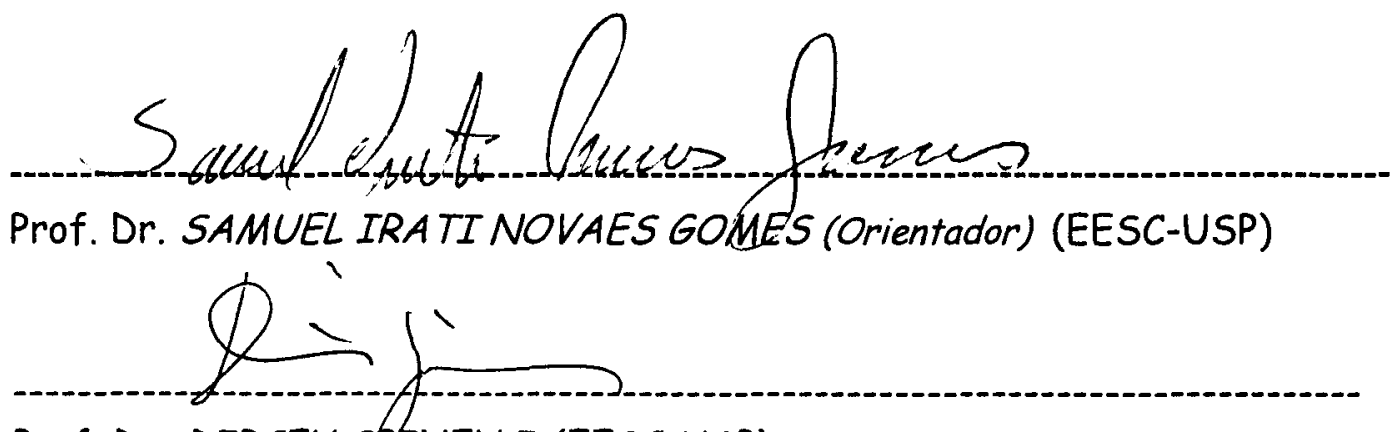

Prof. Dr. OIRCEU SPINELLI (EESC-USP)

Profa. Dra. LAURALICE DE CAMPOS FRANCESCHINI CANALE (EESC-USP)

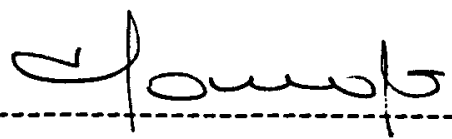

Prof. Dr. THOMAZ TOSHIMI ISHIKAWA (UFSCar)

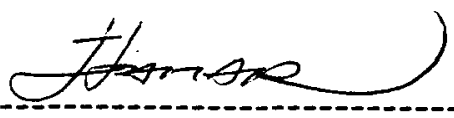

Prof. Dr. ITAMAR FERREIRA (UNICAMP) 


\section{O sábio e o ignorante}

As alegrias da compreensão são os tesouros de Deus; Ele assinala a cada um sua parte na medida que a Ele Lhe parece bem.

Ele o dotou de sabedoria? Te iluminou a mente com o conhecimento da verdade? Comunique aos ignorantes de forma que você os instrua; comunique isto aos sábios, para sua própria melhoria.

A verdadeira sabedoria presume menos que a loucura, o SÁBIO duvida muitas vezes e muda suas idéias.

O TOLO é obstinado e não duvida; ele conhece todas as coisas, menos sua própria ignorância. A vaidade da mente vazia é uma abominação; e a muita conservação é a tolice da loucura; porém, uma parte da sabedoria é suportar com paciência essas impertinências e ter piedade desses absurdos.

Porém, não inches com sua própria vaidade, nem ostente de ter uma inteligência superior ; o conhecimento humano mais límpido não passa de cegueira e loucura.

O SÁBIO conhece suas imperfeições e é humilde; ele trabalha em vão para obter sua própria qualificação.

Mas o TOLO olha para a corrente plana da própria mente e se encanta com as pedras pequenas que ele olha no fundo; as apanha e as mostra como se elas fossem pérolas, e com o aplauso dos seus semelhantes goza e se deleita; se vangloria de ter alcançado coisas que não têm valor algum; mas quando é uma vergonha ser ignorante, então nada entende. Ainda dentro dos caminhos da sabedoria, ele só procura uma loucura; e a vergonha e a decepção são a recompensa do seu trabalho.

Mas o SÁBIO cultiva sua mente com conhecimentos; sua delícia está no progresso das artes, e a utilidade de seus trabalhos para com seu público, o coroa com honrarias. Porém, ele tem como a sabedoria mais alta o alcançar a virtude, e a ciência da felicidade é o estudo de sua própria vida. 
DEDICATORIA

Ao meu filho VITOR

Aos meus pais GIL e ANTONIETTA 


\section{AGRADECIMENTOS}

- Ao Prof. Assoc. Samuel Irati Novaes Gomes, pela amizade, conhecimentos transmitidos e orientação neste trabalho.

- Ao Prof. Dr. Wladimir Waldek Bose Filho pelo apoio e amizade.

- Aos demais professores, técnicos e funcionários do Departamento de Engenharia de Materiais da EESC - USP, pela colaboração, direta ou indireta, neste trabalho.

- Aos colegas pós-graduandos da Área Interunidades em Ciência e Engenharia de Materiais - USP - São Carlos, pela amizade estimulante e pela enriquecedora troca de idéias.

- Ao Sr. Luis Alberto Penazzi e técnicos da oficina mecânica da EESC - USP pela confecção dos corpos de prova. 


\section{SUMÁRIO}

RESUMO iv

ABSTRACT V V

LISTA DE FIGURAS vi

LISTA DE TABELAS vii

LISTA DE ABREVIATURAS E SÍMBOLOS vii

$\begin{array}{ll}\text { 1. INTRODUÇÃO } & 01\end{array}$

$\begin{array}{ll}\text { 2.OBJETIVO } & 02\end{array}$

3. REVISÃO BIBLIOGRÁFICA 03

3.1. Soldagem a Arco Submerso 03

3.1.1. Variáveis do Processo Arco Submerso 05

3.2. Soldagem a Arco Submerso com Adição de Pó Metálico 08

3.3. Aços de Alta Resistência e Baixa Liga 10

3.3.1. Soldagem dos Aços ARBL 10

3.4. Microestrutura do Metal de Solda 12

3.4.1. Identificação dos Microconstituintes 13

3.5. Fatores que Controlam a Microestrutura do Metal de Solda 16

3.5.1. Microestrutura de Solidificação 16

3.5.2. Ciclo de Resfriamento 17

3.5.3. Composição Química do Metal de Solda 17

3.5.4. Inclusões não Metálicas 23

3.5.5. Tamanho de Grão da Austenita Anterior 24

3.6. Influência da Microestrutura na Tenacidade 25

3.6.1. Inclusões 25

3.6.2. Tamanho de Grão 26

3.6.3. Produtos de Transformação 27

3.7. Efeitos do Tratamento Térmico Pós-Soldagem 30 
4. MATERIAIS E MÉTODOS 37

4.1. Materiais $\quad 37$

4.2. Métodos 38

4.2.1. Procedimentos de Soldagem 38

4.2.2. Análises Químicas 41

4.2.3. Metalografia 41

4.2.4. Ensaios Mecânicos 42

5. RESULTADOS 47

5.1. Análises Químicas $\quad 47$

5.2. Diluição da Chapa Base 48

5.3. Exames Metalográficos 48

5.3.1. Macrografias 49

5.3.2. Micrografias 53

5.4. Ensaios Mecânicos 64

5.4.1. Ensaio de Dureza Vickers 64

5.4.2. Ensaio de Tração 64

5.4.3. Ensaio de Impacto Charpy 65

$\begin{array}{ll}\text { 5.4.4. Ensaio CTOD } & 73\end{array}$

$\begin{array}{ll}\text { 6. DISCUSSÃO } & 75\end{array}$

7. CONCLUSÕES 96

$\begin{array}{ll}\text { 8. BIBLIOGRAFIA } & 98\end{array}$ 


\section{RESUMO}

Estudos anteriores mostraram que a soldagem de aço USI-SAC-50 com adição de pó metálico pode promover o aparecimento de microfases que interferem nas propriedades mecânicas.

Este trabalho teve o objetivo de estudar os efeitos de variações nos consumiveis, aporte de calor e do tratamento térmico pós-soldagem na diminuição ou eliminação das microfases.

Chapas de aço USI-SAC-50 foram soldadas por arco submerso com adição de pó metálico utilizando-se fluxos de soldagem BX-200 e OK-1071, arames de soldagem EM-12K e EB-2 e aportes de calor de $4,8 \mathrm{~kJ} / \mathrm{mm}$ e $3,6 \mathrm{~kJ} / \mathrm{mm}$. Tensão e corrente foram mantidas em $34 \mathrm{~V}$ e $600 \mathrm{~A}$, respectivamente. Após a soldagem, metade das chapas foi submetida a um tratamento térmico de alívio de tensões a $580^{\circ} \mathrm{C}$ por $1 \mathrm{~h}$. Foram realizados ensaios mecânicos de dureza, tração a $-10^{\circ} \mathrm{C}$ e CTOD a $-10^{\circ} \mathrm{C}$, assim como foram realizadas metalografias preto e branco e coloridas para identificação $e$ quantificação de fases.

As composições químicas obtidas nos cordões de solda foram adequadas para que a quantidade de ferrita acicular presente assegurasse as boas propriedades mecânicas. As mudanças na composição química, em relação à trabalhos anteriores, ocasionadas pela variação dos fluxos e as variações nos aportes de calor promoveram uma sensivel diminuição na quantidade de microfase para faixa de 2,5 a $10 \%$. Entre os cordóes ensaiados para avaliação de CTOD aquele com maior teor de austenita retida apresentou um CTOD menor, mostrando a influência dessa fase sobre a tenacidade. Também o tratamento térmico de alivio de tensões contribuiu para a diminuição da quantidade de microfase para a faixa de 0 a $1,5 \%$, sendo que a microfase restante apresentou uma forma esferoidal. 


\begin{abstract}
Previous studies showed that the welding of steel USI-SAC-50 with addition of metal powder can promote the appearing of one phase that interfere in the mechanical properties.

This work had the objective of studying the effects of variations in the consumable ones, contribution of heat input and of the thermal treatment in the decrease or elimination of this phase.

Plates of steel USI-SAC-50 were welded by submerged arc weld with addition of metal powder being used welding fluxes BX-200 and OK-1071, welding wires EM-12K and EB-2 and heat inputs of $4,8 \mathrm{~kJ} / \mathrm{mm}$ and $3,6 \mathrm{~kJ} / \mathrm{mm}$. Tension and current were maintained in $34 \mathrm{~V}$ and $600 \mathrm{~A}$, respectively.

After the welding, half of the plates was submitted to a thermal treatment of relief of tensions to $580 \mathrm{C}$ for $1 \mathrm{~h}$.

Mechanical tests of hardness, traction to $-10 \mathrm{C}$ and CTOD to $-10 \mathrm{C}$ were carried out, as well as black and white and colored metalographies were carried out for identification and quantification of phases.

The chemical compositions obtained in the weld beads they were appropriate so that the amount of acicular ferrite present assured the good mechanical properties.

The changes in the chemical composition, in relation to previous works, caused by the variation of the fluxes and the variations in the heat inputs they promoted a sensitive decrease in the amount of microphase for strip from 2,5 to $10 \%$.

The thermal treatment of relief of tensions also contributed to the decrease of the amount of microphase for the strip from 0 to $1,5 \%$, and the remaining microphase presented a spherical shape.
\end{abstract}




\section{LISTA DE FIGURAS}

Figura 3.1 - Esquema do processo SAW

03

Figura 3.2 - Componentes do equipamento SAW

04

Figura 3.3 - Microconstituintes IIW

16

Figura 3.4 - Resistência à clivagem $\times$ Ferrita Acicular 31

Figura 4.1 - Chanfro da chapa base

40

Figura 4.2 - Equipamento de soldagem 41

Figura 4.3 - Amostra de análise química 43

Figura 4.4 - Medidas de dureza 45

Figura 4.5 - C. P. de tração 45

Figura 4.6 - Posição do C. P. de tração 46

Figura 4.7 - Dispositivo para ensaio de tração 46

Figuras 5.1 a 5.4 - Macrografias 50 a 53

Figuras 5.5 a 5.6 - Micrografias preto e branco 55-56

Figuras 5.7 a 5.14 - Micrografias coloridas 57 a 64

Figuras 5.15 a 5.22 - Curvas Charpy 66 a 73

Figuras 5.23 a 5.24 - Curvas CTOD 74-75

Figura 6.1 - cordões $\times \%$ AF 79

Figura 6.2 - cordões $\times \%$ austenita retida 81

Figura 6.3 - cordōes $x$ dureza HV

Figura 6.4 - cordões $x$ limite de escoamento

Figura 6.5 - cordões $x$ patamar de energia dúctil 86

Figura 6.6 - teor de $O \times$ patamar de energia dúctil 86

Figura 6.7 - ferrita acicular $\times$ AFTT 88

Figura 6.8 - cordōes $\times$ CTOD 90

Figura 6.9 - cordöes $\times \%$ austenita retida 91

Figura 6.10 - cordões $x$ dureza HV - após alivio de tensōes 92

Figura 6.11 - cordões $x$ limite de escoamento - após alívio de tensões $\quad 94$

Figura 6.12 - cordões x patamar de energia dúctil - após alívio de tensões 95 


\section{LISTA DE TABELAS}

Tabela 4.1 - Composições químicas - materiais 39

Tabela 4.2 - Composições químicas - fluxos 39

Tabela 4.3 - Condições de soldagem 41

Tabela 4.4 - Identificação das chapas $\quad 42$

Tabela 5.1 - Análise química das soldas 48

Tabela 5.2 - Análise de oxigênio e nitrogênio 48

Tabela 5.3 - Diluição da chapa base 49

Tabela 5.4 - Quantificação de fases 54

Tabela 5.5 - Quantificação de microfase 54

Tabela 5.6 - Ensaio de dureza $\quad 65$

Tabela 5.7 - Ensaio de tração 65

Tabela 6.1 - Resultados Charpy 85

Tabela 6.2 - Resultados Charpy - após tratamento 94

\section{LISTA DE ABREVIATURAS E SÍMBOLOS}

AF ferrita acicular

AFTT aparência da fratura na temperatura de transição

ARBL alta resistência baixa liga

ASTM American Society of Mechanical Engineers

AWS American Welding Society

FC agregado de ferrita/carbeto

FC(B) perlita

FS ferrita com segunda fase

FS(A) ferrita com segunda fase alinhada

FS(B) bainita

FS(LB) bainita inferior

FS(NA) ferrita com segunda fase não alinhada

FS(SP) ferrita de Widmanstäten

FS(UB) bainita superior 


$\begin{array}{ll}H V_{10} & \text { dureza Vickers com carga de } 10 \mathrm{~kg} \\ \text { IIW } & \text { International Institute of Welding } \\ \text { M } & \text { martensita } \\ \text { M/A } & \text { martensita/austenita } \\ \text { M-A-C } & \text { martensita-austenita-carboneto } \\ \text { PF } & \text { ferrita primária } \\ \text { PF(G) } & \text { ferrita de contorno de grão } \\ \text { PF(I) } & \text { ferrita poligonal intragranular } \\ \text { ppm } & \text { partes por milhão } \\ \text { ZTA } & \text { zona termicamente afetada } \\ & \\ \gamma & \text { campo austenítico do diagrama Fe-C } \\ \alpha & \text { campo ferrítico do diagrama Fe-C } \\ \varphi & \text { estricção } \\ \sigma & \text { tensão de escoamento } \\ \sigma_{0} & \text { tensão de atrito que se opõe ao movimento das discordâncias } \\ \sigma_{\mathrm{r}} & \text { limite de resistência }\end{array}$




\section{1 - INTRODUÇÃO}

A necessidade de se conseguir melhorias de qualidade e produtividade nas construções obtidas através do processo de soldagem a arco submerso fez surgir novos procedimentos de soldagem com o intuito de se alcançar esse objetivo.

O maior obstáculo que se apresenta vem do fato de que o aumento da produtividade estaria ligado ao aumento do aporte de calor para se obter um conseqüente aumento na taxa de deposição. Esse aumento no aporte de calor traria o problema de aumentar a diluição do metal de base e produzir uma grande zona afetada pelo calor, com conseqüente degradação da tenacidade a fratura.

A soldagem a arco submerso com adição de pó metálico é um método que alia alta produtividade com boas propriedades mecânicas, aumentando a taxa de deposição sem acrescer a quantidade de calor que irá afetar a chapa base. Sua utilização cada vez maior requer estudos que determinem as melhores combinações de consumiveis para atender as exigências das normas em relação à tenacidade à fratura.

A adição de pó metálico é mais um fator no controle do metal depositado, haja visto que a microestrutura final do metal de solda vai depender de uma combinação de diversos fatores, como : elementos de liga, inclusōes não metálicas (concentração, composição química e distribuição), microestrutura de solidificação, ciclo de resfriamento da solda e tamanho de grão da austenita.

Um metal de solda que apresenta uma microestrutura com alta porcentagem de ferrita acicular poderá ter alta resistência mecânica e ótima tenacidade à fratura, devido às características desse tipo de microestrutura, seu tamanho muito pequeno e a forma como estão dispostas as placas de ferrita na microestrutura, dificultando a propagação de trincas.

Um dos procedimentos para controlar a quantidade de ferrita acicular no metal depositado, tem sido a combinação dos consumíveis com a diluição 
da chapa base com o intuito de produzir um balanceamento adequado dos elementos de liga .

Contudo, essa combinação deve ser cuidadosamente escolhida de modo a evitar o aparecimento de fases prejudiciais às propriedades mecânicas, como têm mostrado estudos anteriores.

\section{2 - OBJETIVOS}

Com base em estudos anteriores, esse trabalho tem como um dos objetivos identificar a fase prejudicial através de metalografia colorida e microscopia eletrônica.

Através de variações nas combinações de consumíveis em relação aos estudos de referência, mudanças nos eletrodos e fluxos, alterou-se a composição química da solda, de modo a se conseguir uma microestrutura nos moldes desejados.

O tratamento pós soldagem foi realizado em metade das chapas de modo a se fazer as comparações entre as soldas com e sem tratamento.

Para se constatar as propriedades mecânicas da solda obtida com esses parâmetros, foram realizados ensaios de tração, dureza, impacto e CTOD.

Tanto as variações nos consumíveis, quanto o tratamento pós soldagem teve o intuito de diminuir ou eliminar essa fase prejudicial de modo a se obter soldas com as adequadas propriedades mecanicas exigidas pelas normas de utilização desse tipo de aço alta resistência e baixa liga resistente à corrosão atmosférica, utilizado cada vez mais no Brasil na construção de estruturas metálicas. 


\section{3 - REVISÃO BIBLIOGRÁFICA}

\section{1 - Soldagem a arco submerso}

A figura 3.1 esquematiza este processo de soldagem e suas principais características são apresentadas por OKUMURA e TANIGUCHI (1982):

. como o arco e a poça de fusão são totalmente protegidos pelo fluxo, obtém-se um metal depositado de alta qualidade;

. como os arames de enchimento, normalmente, têm grandes diâmetros, as correntes de soldagem também são altas, o que proporciona uma penetração bastante profunda, associada igualmente a uma alta eficiência de deposição;

devido ao alto rendimento térmico do processo, os chanfros da junta são pequenos, permitindo uma alta economia de material consumível;

a soldagem só poderá ser executada na posição plana ou na horizontal;

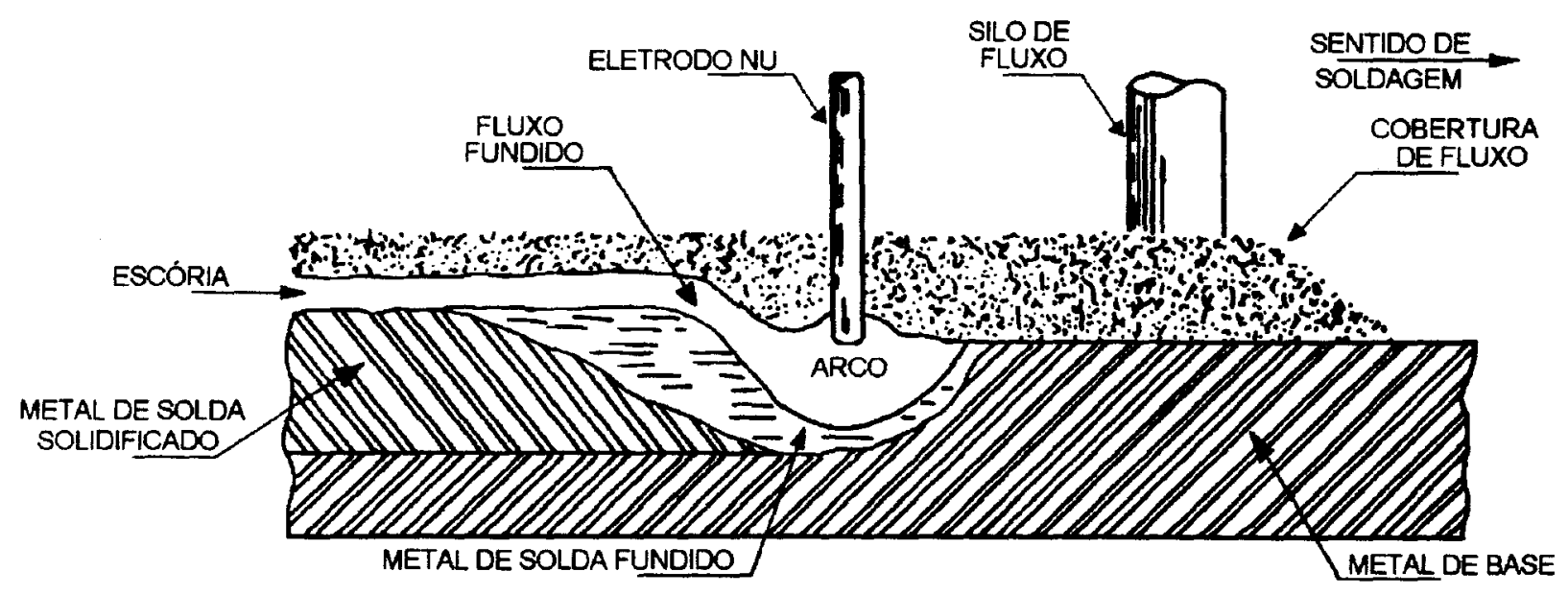

Figura 3.1 - Esquema do processo de soldagem com arco submerso.[WAINER e BRANDI] 


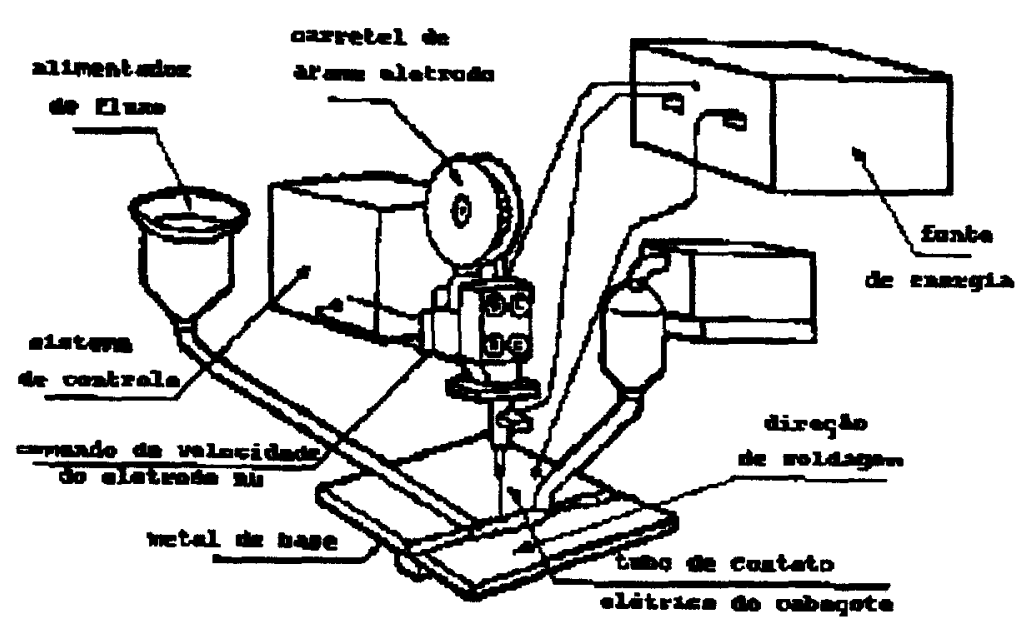

Figura 3.2 - Componentes básicos do equipamento de soldagem com arco submerso.[WAINER e BRANDI]

Existem vários tipos de equipamentos para soldagem por arco submerso, a figura 3.2 apresenta um dos mais comumente empregados na prática. Nele o cabeçote de soldagem é montado sobre um carro, que se movimenta ao longo de trilhos apropriados. O fluxo é alimentado por meio de um tubo, ligado ao reservatório, que também está montado no carro. Um carretel de arame completa o sistema móvel e a sua alimentação se faz por meio de um mecanismo alimentador de arame de enchimento. Para aumentar a velocidade de deposição do processo, costuma-se, muitas vezes, utilizar dois ou três arames de enchimento simultaneamente.

Fontes de alimentação CA com características tombantes e fontes de $\mathrm{CC}$ com tensão constante são utilizadas na soldagem por arco submerso. As primeiras têm um custo acessivel e são facilmente operáveis, tendo ainda como vantagem a eliminação do sopro magnético, mesmo com altas intensidades de corrente. Por outro lado, as fontes de CA exigem um controle mais acurado da velocidade de alimentação do arame. Isto é conseguido através de um circuito apropriado, conforme esquematizado na figura 3.2, no qual a tensão do arco controla a velocidade do eletrodo, para manter o comprimento do arco o mais estável possivel. Já nas fontes de CC, é possivel trabalhar com uma velocidade de alimentação constante e a polaridade 
inversa do arame de enchimento. $\mathrm{O}$ processo $\mathrm{CC}$ é também empregado na soldagem de chapas finas de aço, a altas velocidades e na utilização do método de múltiplos eletrodos.

Ainda de acordo com OKUMURA e TANIGUCH (1982) as propriedades mecânicas da zona de solda obtidas pelo processo de arco submerso são função das características do metal de base e da combinação arame-fluxo empregada na soldagem. A rigor, dependendo do tipo de material-base, deve-se escolher a combinação arame-fluxo mais adequada.

\subsection{1 - Variáveis do processo arco submerso}

Neste processo, cujo grande campo de aplicação é a união de chapas espessas, é especialmente importante conhecer a influência e a interdependência dos parâmetros de soldagem para otimizar o binômio eficácia e eficiência da solda, segundo PAVELEY (1982) :

\section{- Preparação das juntas}

Todas as extremidades devem estar limpas e livres de contaminações tais como óleo, ferrugem, tinta etc. que, se em contato com a poça fundida e o fluxo, podem causar bolhas de gás, porosidade, inclusões de escória e em casos severos, trincamento.

Ângulos de chanfro e a seleção da forma, por exemplo, "U", "K", duplo "V" etc. dependerão da espessura da chapa e das normas de construção da estrutura que está sendo montada.

\section{- Corrente de soldagem}

Dentro de certos limites, o valor da amperagem usado para um particular tamanho de arame determina a taxa de fusão do eletrodo e profundidade de penetração, ou seja, aumentando o valor da corrente, aumentará a taxa de deposição e profundidade de penetração. 
Corrente excessiva causará instabilidade do arco, erosão ("under cutting") e "pregas" no perfil da solda; similarmente abaixo de um certo valor de corrente também ocorrerá instabilidade do arco, desvio do arco e penetração mínima.

Com a polaridade direta ( $\left.\mathrm{CC}^{-}\right)$obtém-se maior consumo, ou seja, tendo em vista que o rendimento de deposição é alto, maior produção de material de adição para solda.

Todavia observa-se uma maior instabilidade do arco com a polaridade direta que vai diminuindo a medida que a corrente aumenta. Este fato, segundo MANTEL apud QUITES (1979), é devido a erraticidade da mancha catódica e formação de grandes gotas metálicas. Na polaridade inversa $\left(\mathrm{CC}^{+}\right)$ a transferência do metal se efetua em gotas menores, atingindo-se o aerossol com facilidade.

\section{- Tensão de soldagem}

Segundo MANTEL apud QUITES (1979) a voltagem do arco afetará a largura e a forma do cordão, assim como a diluição, com a profundidade de penetração permanecendo virtualmente inafetada. Também pode afetar a composição do metal de solda, quanto maiores voltagens e desse modo mais longos comprimentos de arco, mais elementos de liga do fluxo podem ser transferidos para o metal de solda. Altas voltagens de arco também aumentam a probabilidade de sopro magnético.

Observa-se que o consumo cai com o aumento da tensão, o que à primeira vista parece incoerente. Entretanto deve-se atentar para o fato de que, sendo " $t$ " constante, o comprimento do eletrodo (e) diminui, ao mesmo tempo em que o comprimento do arco aumenta. Assim, o consumo do eletrodo diminui a medida que a queda de tensão em seu comprimento diminui.

Quanto à geometria da solda nota-se que, para condições dadas, aumentando-se o valor de "t", aumentam a penetração " $p$ ", o reforço " $r "$, a seção da solda "s", a área adicionada "Sad" e diminui a largura "b". 


\section{- Velocidade de soldagem}

Velocidade de soldagem influencia a largura do cordão e penetração. Velocidades rápidas produzem cordões estreitos que tem menor penetração, o que pode ser vantajoso quando a soldagem é sobre material fino. Contudo, se a velocidade é muito rápida então o resultado pode ser erosão (undercut), porosidade, irregularidade do cordão e redução da resistência ao sopro magnético.

Ao contrário, velocidades excessivamente lentas encorajam o arco a uma erupção através do fluxo, fornecendo um perfil do cordão pobre. A combinação de uma velocidade lenta com valores altos de corrente e voltagem do arco pode resultar em uma largura excessiva e cordão em forma de cogumelo que pode ter propensão a trinca nos ângulos de alargamento.

Tais trincas, de acordo com PAVELEY (1982), são muitas vezes associadas com bandas de segregação do metal base, que provem sítios de iniciação na situação suscetível a trinca do cordão em forma de cogumelo. As trincas são interdendríticas e não propagam necessariamente até a superfície

\section{- Consumiveis}

WAINER e BRANDI (1992) mostram que os fluxos para soldagem com arco submerso são projetados para suportar as elevadas correntes de soldagem usadas no processo. Os fluxos têm a função de proteger a poça de solda contra a ação da atmosfera, atuar como desoxidante, limpando o metal de solda e ainda podem modificar a composição química do metal de solda. De acordo com o método de fabricação, os fluxos podem ser aglomerados ou fundidos.

Os eletrodos para soldagem com arco submerso são fabricados em faixas de composição química especificadas e trefiladas até os diâmetros desejados. São normalmente cobreados, a fim de evitar oxidações superficiais durante $\mathrm{o}$ armazenamento. 
O sistema de classificação, comumente utilizado no Brasil para consumiveis, fluxos e eletrodos, na soldagem com arco submerso, é o definido pela American Welding Society A 5.17-80 e A 4.23-80 contém especificações para fluxos e eletrodos utilizados na soldagem de aços carbono e de baixa liga, respectivamente.

Os fluxos são classificados com base nas propriedades mecânicas do metal de solda, em conjunto com uma classificação particular de eletrodo nu.

Os eletrodos são classificados somente com base em sua composição quimica, sendo os diâmetros do eletrodo nu padronizados.

Devido à grande variedade de fluxos e tipos de eletrodos do mercado, há um número maior ainda de combinações fluxo/eletrodo possiveis.

A seleção do fluxo e do eletrodo nu deve servir a um objetivo específico. Por exemplo, ser escolhido para soldagem em geral de baixo custo, ou para obter requisitos metalúrgicos especiais, como propriedades de impacto, resistência a tração, dureza, etc. ....

\section{2 - Soldagem a Arco Submerso com Adicão de Pó metálico}

A origem desse processo de adição de pó metálico é citada por REYNOLDS e KACHELMEIR (1978) que descrevem o primeiro resultado obtido na aplicação de revestimento superficial para melhorar a resistência ao desgaste de equipamentos da indústria petroquímica, onde constatou-se, além do aumento da taxa de deposição um menor consumo de fluxo e um decréscimo no aporte de calor transferido para a chapa base, o que reduziu a zona termicamente afetada (ZTA). A diminuição do aporte de calor foi atribuída à absorção de parte da energia do arco elétrico para fundir o pó metálico, assim como TROYER e MIKURAK (1974) mostraram que o ganho em produtividade decorre do fato do pó metálico ser totalmente fundido no metal de solda, aumentando a quantidade de material depositado.

CAMPBELL e JOHNSON apud KOBAYASHI (1995) justificaram que devido à característica com que o arco incide sobre a junta, grande parte da 
energia do arco é concentrada principalmente para fundir as bordas do metal de base e o restante da energia é utilizada para fundir os consumiveis (arame e fluxo), o que pode resultar em excessiva penetração e alta diluição da chapa base. A presença de um consumível extra (como o pó metálico) na poça fundida faz com que o excesso de energia disponivel do arco ao invés de somente fundir o metal de base seja também utilizado para fundir o metal adicional, resultando em uma menor penetração. A contribuição da diluição é substituída pela contribuição dos elementos de liga fornecidos a partir da adição do pó metálico.

FRASER et alli (1982) citam que com $\circ$ aumento do tamanho e complexidade das estruturas de aço das plataformas de petróleo, na última década, houve o correspondente crescimento na extensão da solda, particularmente àquelas obtidas por arco submerso, usadas nessas construçōes. Isto levou à busca de soluções para soldas de maior produtividade, sem obviamente aumentar 0 custo de montagem das plataformas.

Neste trabalho eles citam algumas vantagens da técnica de adição de pó metálico, como : custo relativamente baixo devido a simplicidade dos acessórios necessários , fácil adaptação dos equipamentos de arco submerso já existentes, efetivo controle da taxa de alimentação de pó , conseqüente alta reprodutibilidade e redução do consumo de fluxo.

FRASER et ali (1982) mostraram também nesse trabalho que a adição a frente do fluxo, ao mesmo tempo em que forneceram um aumento na taxa de deposição, contribuíram significativamente para que as propriedades mecânicas dos metais de solda, depositados por uma combinação particular de consumiveis e pó metálico, excedessem os critérios exigidos em aplicações críticas, tais como as verificadas em plataformas de petróleo que operam no Mar do Norte.

Vários pesquisadores apontam a quantidade de pó metálico adicionada e a compatibilidade de composição química com os consumiveis como os 
principais fatores que podem influenciar as propriedades mecânicas a serem obtidas e, por conseguinte, a qualidade final do metal de solda.

\section{3 - Acos Alta Resistência e Baixa Liga (ARBL)}

Desenvolvidos a partir dos aços C-Mn laminados a quente, a maioria dos aços que se enquadram nessa classe não adquirem boas características de resistência mecânica unicamente pelos tratamentos térmicos convencionais, como por exemplo os aços temperados e revenidos.

Segundo PORTER e REPAS (1982) níveis satisfatórios de resistência mecânica, tenacidade, conformabilidade, soldabilidade e resistência a corrosão atmosférica, são obtidos através de uma ação conjunta de adequadas adições de elementos de liga e tratamentos térmicos convencionais, como por exemplo normalização, ou ainda, tratamentos termomecânicos, como por exemplo a laminação controlada.

Atualmente, dentre as numerosas aplicações, os aços ARBL têm encontrado grande aceitação no campo das grandes construções metálicas como por exemplo, as plataformas marítimas de exploração de petróleo.

\subsection{1 - Soldagem dos Acos ARBL}

De acordo com LIU e BRACARENSE, nos aços ARBL, elementos como $\mathrm{Mn}, \mathrm{Ni}, \mathrm{Cr}$, Mo e $\mathrm{Cu}$ desempenham um papel importante proporcionando resistência acima de $70 \mathrm{kgf} / \mathrm{mm}^{2}$ (100 Ksi). Outros elementos, tais como $\mathrm{Nb}, \mathrm{V}$ e Ti são adicionados em pequenas quantidades para controlar o tamanho de grão austenítico e ferritico, controlando desta forma, a tenacidade do metal. A microestrutura destes aços pode variar de completamente ferrita acicular para aços com resistência abaixo de $70 \mathrm{kgf} / \mathrm{mm}^{2}$ até uma estrutura tipicamente bainítica-martensítica, para aços com resistência igual ou acima de $70 \mathrm{kgf} / \mathrm{mm}^{2}$. 
Estudos têm mostrado que a introdução de ferrita acicular no metal de solda destes aços, a partir do controle da nucleação de ferrita de contomo de grão, reduz a dureza da microestrutura, mas por outro lado, aumenta a tenacidade a niveis aceitáveis. Tem sido também muito bem documentado que $\mathrm{B}, \mathrm{Ti}, \mathrm{Al}$ e $\mathrm{Zr}$ são eficientes na promoção de ferrita acicular em aços de alta resistência e baixa liga.

Levando em consideração o que foi comentado até aqui, pode-se concluir que um fator muito importante à ser considerado na soldagem do aços de alta resistência e baixa liga, é conseguir a composição química adequada no metal de solda. Neste sentido, desconsiderando a atmosfera, a qual pode ser responsável por introduzir oxigênio e nitrogênio no metal líquido, existem três fontes principais de elementos químicos para o metal de solda: $\mathrm{O}$ arame, o fluxo (ou gás) , o metal de base e, no caso do processo de com adição de pó metálico, o próprio pó metálico. Com relação às reações metal/fluxo, um conceito que tem sido muito utilizado é o da "quantidade delta".

A quantidade delta expressa o comportamento quimico da reação entre o metal com o fluxo, ambos no estado líquido. Com base na diferença entre o teor nominal de um elemento e a concentração medida deste elemento no metal de solda

$$
\Delta \mathrm{X}=\mathrm{X}_{\text {medido }}-\mathrm{X}_{\text {nominal }}
$$

- comportamento fluxo/metal de solda pode ser avaliado. O teor nominal de um elemento é baseado nas concentrações deste elemento no arame, no metal de base e a diluição. Um valor negativo da quantidade delta significa que o elemento foi transferido do metal de solda para a escória. Da mesma forma, um valor positivo significa que o elemento foi transferido da escória para o metal de solda. Preocupados com a influência do fluxo na composição química do metal de solda de aços de alta resistência, DALLAN et 
ali (1985) e OLDLAND et ali (1988) utilizaram o conceito de "quantidade delta" para descrever as atividades dos fluxos e a interação fluxo-metal.

DALLAN et ali (1985) utilizando fluxo no sistema $\mathrm{CaF}_{2}-\mathrm{CaO}-\mathrm{SiO}_{2}$, tipo básico, para aços de alta resistência e baixa liga, verificaram que existe uma região neste sistema onde 0 delta silício é zero. Conhecendo o comportamento de participação dos elementos entre a escória e o metal de solda, pode-se formular fluxos que vão controlar precisamente a composição química do metal de solda, adicionando ou removendo os elementos de acordo com as necessidades e as propriedades desejadas.

Em um outro importante trabalho, SIEWERT e FRANKE(1989) investigaram técnicas de análise, caracterização e definição de fluxos para arco submerso, utilizando técnicas tais como espectrometria de emissão ótica, fluorescência de raioX e difração de raio-X, além de comparação dos efeitos do tamanho das partículas do fluxo.

\section{4 - Microestruturas do metal de solda}

Em trabalho de COCHRANE (1983) é dito que a busca por melhores níveis de tenacidade ao impacto em metais de solda tem levado à apreciação da complexidạde das relações entre microestrutura e tenacidade. Desta forma tem-se tido considerável interesse em como a microestrutura do metal de solda é formada e como ela pode ser relacionada com cinéticas de transformação de composições particulares de solda.

Ainda de acordo com COCHRANE (1983) a escolha dos consumiveis, arame, fluxo e pó metálico, rege, em larga escala, a composição do metal de solda que será produzido, lembrando, contudo, que esta composição também será influenciada pela diluição da chapa base.

Diferenças nas formulações dos fluxos podem produzir inclusões, e é reconhecido que estas inclusões têm papel importante na formação da microestrutura. Estudos têm mostrado que o provável papel dessas inclusões é ser um substrato heterogêneo para nucleação de várias formas de ferrita. 
Segundo COCHRANE (1983) composiçōes de metal de solda comumente encontradas em fabricação solidificam como ferrita- $\delta$ e subseqüentemente transforma para austenita, e então para ferrita. Ë possivel que, sob certas condições especiais, a solidificação ocorra diretamente para austenita. Há evidências, portanto, de que o modo de solidificação é um fator determinante da microestrutura final. Uma vez mais deve-se dizer que o aparecimento de inclusões também será importante neste estágio do desenvolvimento microestrutural.

TAYLOR e FARRAR (1975) consideram que em termos de importância microestrutural para 0 metal de solda é a subsequente decomposição da austenita na faixa de temperatura crítica que caracteriza as transformações de fases no estado sólido. Desta forma, dependendo da composição quimica participante e da velocidade de resfriamento imposta pelo ciclo térmico de soldagem, essa austenita pode se decompor em uma variedade de constituintes microestruturais, sendo cada um deles particular no que concerne a cinética de transformação $e$, até certo ponto em sua morfologia.

\subsection{1 - Identificacão dos Microconstituintes}

De acordo com o IIW (International Institute of Welding - 1988), baseado na análise morfológica realizada por microscopia ótica, que permite classificar os principais constituintes microestruturais de metais de solda ferríticos, na condiçăo como soldada, com a seguinte terminologia : ferrita primária, ferrita acicular, ferrita com segunda fase, agregado ferrita carboneto e martensita.

Com a exceção da martensita, a distinção entre os outros constituintes microestruturais pode ser esquematicamente visualizada através das ilustrações contidas na figura 3.3, com as correspondentes caracteristica morfológicas transcritas como segue: 
- Ferrita primária (PF)

Engloba as morfologias de contorno de grão e a intragranular. A primeira, $P F(G)$, é caracterizada como veios, ou também grãos equiaxiais, associados aos contornos dos grãos colunares da austenita anterior, enquanto que a segunda, $\mathrm{PF}(\mathrm{I})$, compreende aos. grãos poligonais de ferrita contidos no interior dos referidos grãos colunares.

\section{- Ferrita acicular (AF)}

A morfologia desse constituinte é tipicamente caracterizada como pequenos grãos de ferrita, não alinhados, isolados ou não, e encerrados dentro dos grãos colunares da austenita anterior. Os grãos isolados normalmente apresentam elevada relação de aspecto.

- Ferrita com segunda fase (FS)

Em função do posicionamento da fase secundária em relação a ferrita, as morfologias alinhadas e não alinhadas são possiveis de identificação. A morfologia alinhada, FS(A), é caracterizada pela incidência da fase secundária entre ripas paralelas de ferrita. Particularizações em termos de ferrita de placas laterais ( $F S(S P))$, bainita ( $F S(B)$ ), ou mais especifico ainda, as bainitas superior ( $F S(\mathrm{UB})$ ) e inferior ( $\mathrm{FS}(\mathrm{LB})$ ), também são previstas. A morfologia não alinhada, FS(NA), caracteriza-se pela presença de grãos de ferrita circundados tanto por microfases, quanto por ripas isoladas de ferrita acicular de elevada relação de aspecto.

- Agregado ferrita-carboneto (FC)

Esse constituinte pode ser interpretado como uma mistura de ferrita e carbonetos, incluindo a perlita e a ferrita com carboneto interfásico, de tamanho bastante refinado, cuja resolução freqüentemente fica abaixo da obtida por microscopia ótica. A especificação única com respeito a perlita $(\mathrm{FC}(\mathrm{P})$ ) também é prevista. Em relação ao tamanho do agregado, observa-se que no caso de uma incidência bem menor das ripas adjacentes de ferrita, esse constituinte pode ser tratado como uma microfase. 

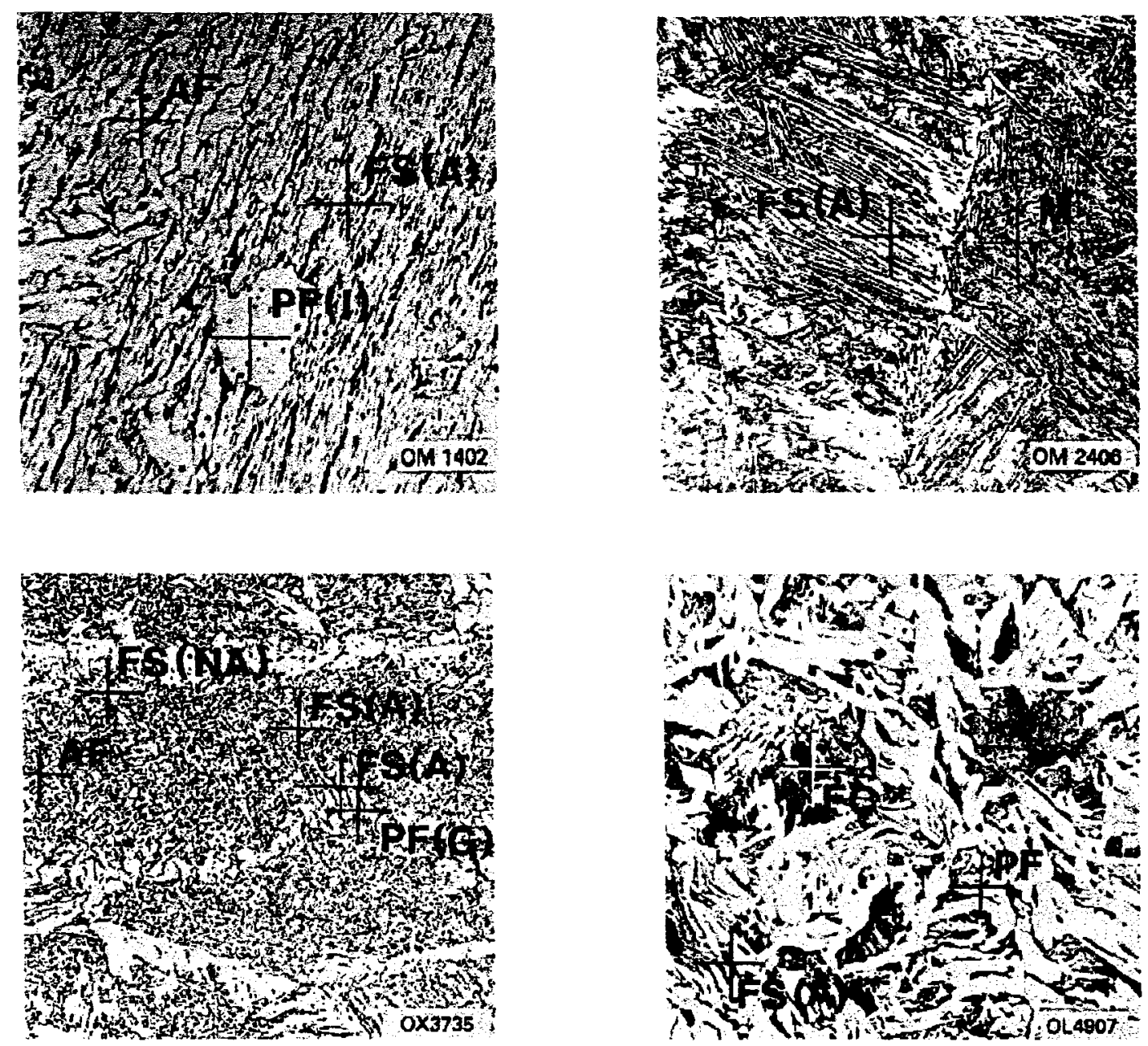

Figura 3.3- Representações esquemáticas dos constituintes microestruturais que podem ser avaliados em metais de solda ferríticos, segundo o IIW:

AF ferrita acicular

FC agregado de ferrita/carbeto

FS(A) ferrita com segunda fase alinhada

FS(NA) ferrita com segunda fase não alinhada

M martensita

PF ferrita primária

PF(G) ferrita de contorno de grão

$\mathrm{PF}(\mathrm{I}) \quad$ ferrita poligonal intragranular 
- Martensita (M)

Devido também a dificuldade de resolução com a microscopia ótica, a morfologia desse constituinte é interpretada sob a forma de colônias, que devem ser maiores que as ripas adjacentes de ferrita. Em ocorrendo o contrário, as mesmas podem ser consideradas como microfases. A diferenciação da martensita em ripas $(M(L))$ e martensita maclada $(M(T))$, também são previstas.

\section{5 - Fatores que Controlam a Microestrutura no Metal de Solda}

\subsection{1 - Microestrutura de Solidificacão}

De acordo com SAVAGE (1975), a solidificação do metal de solda inicia-se por nucleação heterogênea e crescimento epitaxial na chapa base. Os grãos desenvolvem-se com a mesma orientação cristalográfica e tamanho dos grãos da zona termicamente afetada (ZTA) que agem como substrato.

Segundo GARLAND e KIRKWOOD, a solidificação da poça de fusão segue na direçăo do máximo gradiente térmico, ou seja, na direção normal a linha de fusão e continua até os grãos se tocarem. A quantidade de elementos de liga, taxa de crescimento e gradiente térmico na poça de fusão irão determinar se a subestrutura do grão colunar será dendrítica, celulardendrítica ou celular.

A segregação de elementos de liga e impurezas $(C, O, M n, S, P)$ pode ocorrer nos espaços interdendríticos. A macrosegregação na forma de bandas de soluto tende a ocorrer na linha central da solda, o que pode produzir trincas a quente pela formação de eutéticos de baixo ponto de fusão. Após a transformação $\gamma \rightarrow \alpha$, um alto grau de segregação pode levar à formação de blocos de martensita e bainita. 


\subsection{2 - Ciclo de Resfriamento}

Para se ter uma idéia das condições térmicas sob as quais a transformação $\gamma \rightarrow \alpha$ ocorre, utiliza-se o tempo de resfriamento de $800^{\circ}$ a $500^{\circ} \mathrm{C}$.

Estudos feitos por GLOVER et. al. (1977) mostraram que para metal de solda de aços ARBL aumentando-se a taxa de resfriamento houve mudança na microestrutura de ferrita poligonal para ferrita acicular e para bainita superior. Na faixa de $15<\Delta t<190 \%$ foi observada a presença da microfase M-A.

HARRISON e FARRAR (1987) estudaram o efeito da taxa de resfriamento no desenvolvimento da microestrutura do metal de solda de aços C-Mn e C-Mn-Ni por dilatometria. Verificaram que para taxas de resfriamento baixas(100 s) a microestrutura era ferrita poligonal e perlita; para taxas de resfriamento intermediárias (20s) a microestrutura era predominantemente ferrita acicular e para altas taxas (1.5s) formou-se martensita.

NOVAES GOMES et al. (1993) verificaram o efeito do insumo de calor sobre a microestrutura e composição química das soldas feitas por arco submerso. Observaram que com o aumento do insumo de calor houve crescimento do tamanho médio do grão colunar do metal depositado e para os metais de solda com maior tamanho médio do grão colunar a porcentagem de ferrita de contorno aumentou em relação à da ferrita acicular.

\subsection{3 - Composicăo Química do Metal de Solda}

\section{Influência do Carbono (C)}

O carbono é o mais importante elemento no metal de solda e deve ser mantido na faixa de $0,05 \%$ a $0,15 \%$ para que não ocorra a formação de martensita. Nesse niveis o carbono tem efeito de controlar a quantidade de carbetos e refinar a microestrutura. 
EVANS (1983) variou o carbono de $0,045 \%$ a $0,145 \%$ e variou o manganês de $0,6 \%$ a $1,8 \%$ em soldagem por eletrodo revestido e verificou, no metal de solda, que aumentando-se o teor de carbono aumenta-se a ferrita acicular às custas da ferrita poligonal de contorno.

SVENSSON \& GRETOFT (1990) estudaram o efeito do C na microestrutura do metal de solda de cordões feitos por eletrodo revestido. Com o aumento do teor de $\mathrm{C}$ houve aumento na porcentagem de ferrita acicular às custas da ferrita de contorno de grão e ferrita com segunda fase e também observaram um aumento no número de microfases.

SURIAN et al. (1991) variou o carbono de $0,05 \%$ a $0,12 \%$ em eletrodos para SMAW e verificou, no metal de solda, que aumentando-se o teor de carbono aumenta-se a dureza; aumenta-se os limites de resistência e de escoamento na condição como soldado e com alívio de tensão; diminui-se a energia ao impacto Charpy- $V$ nas condições como soldado e com alívio de tensão.; aumenta-se a proporção de ferrita acicular enquanto que a proporção de ferrita de contorno diminuiu na condição como soldado mas com alívio de tensão aumentou-se a precipitação de carbetos.

\section{Influência do Manganês (Mn)}

O manganês é o principal elemento reforçador por solução sólida em aços estruturais quando está presente em quantidades maiores que $1 \%$.

Estudos feitos por EVANS (1980), em soldas feitas com eletrodo revestido variando-se o teor de Manganês de $0.65 \%$ a $1.8 \%$, mostraram que aumentando-se o teor de manganês, aumentou-se a porcentagem de ferrita acicular às custas da ferrita pró-eutetóide e de componentes lamelares (ferrita com segunda fase), e a ferrita tornou-se mais refinada.

Estudos feitos por HARRISON e FARRAR (1987), usando dilatometria, em cordões de solda feitos com eletrodo revestido, mostraram que o aumento do teor de manganês abaixou as temperaturas de início de transformação austenita-ferrita em diagramas CCT para todas as taxas de resfriamento. Com o aumento de teor de manganês houve maior abaixamento da temperatura de 
início da formação da ferrita poligonal do que da ferrita acicular, resultando assim em um aumento progressivo da ferrita acicular.

SVENSSON e GRETOFT (1990) estudaram o efeito do Mn na microestrutura do metal de solda de cordões feitos por eletrodo revestido. Com o aumento no teor de $\mathrm{Mn}$ houve aumento na porcentagem de ferrita acicular às custas da ferrita com segunda fase e também houve aumento no número de microfases e estas tornaram-se mais segregadas.

\section{Influência do Silício (Si)}

EVANS (1986) estudou o efeito do silício na microestrutura de cordões de solda feitos com eletrodo revestido variando-se o teor de Si entre $0.2 \%$ e $0.9 \%$. Com o aumento do teor de Si houve aumento da porcentagem de ferrita acicular às custas da ferrita pró-eutetóide e da ferrita com segunda fase. Exames de réplicas de extração de carbono revelaram que as microfases retidas poderiam ser austenita ou austenita/martensita.

Segundo ABSON apud EVANS (1986) que estudou cordōes de solda de passes simples feitos com arco submerso, com o aumento do teor de silício houve aumento da ferrita acicular no metal de solda mas sem o refino da microestrutura ser observado e também o Si promoveu a formaçăo de microfase.

\section{Influência do Cromo (Cr)}

EVANS (1989) estudou o efeito do Cromo na faixa de $0 \%$ a $2.3 \% \mathrm{em}$ soldas de múltiplos passes feitas com eletrodo revestido, contendo manganês de $0.6 \%$ a $1.8 \%$. Com o aumento do teor de $\mathrm{Cr}$ houve redução da ferrita primária acompanhada inicialmente por aumento da ferrita acicular e depois por aumento da ferrita com segunda fase alinhada. Estas mudanças nas porcentagens microestruturais variaram com o teor de $\mathrm{Mn}$. Até $1 \%$ de $\mathrm{Cr}$ houve refinamento progressivo da ferrita acicular. Sem $\mathrm{Cr}$ a microfase retida era tipo perlítica; com $0.25 \%$ a microfase era predominantemente 
martensita/austenita (M/A) e com teores mais altos a microfase $M-A$ estava dispersa e irregular na forma.

SNIEDER e KERR (1984) estudaram o efeito do cromo na microestrutura e propriedades do metal de solda feito por arco submerso com fluxo básico. A microestrutura apresentou-se aproximadamente $90 \%$ como ferrita acicular entre $0.032 \% \mathrm{Cr}$ e $0.73 \% \mathrm{Cr}$ mas com teores maiores de $0.4 \%$ $\mathrm{Cr}$ houve supressão da formação de ferrita pró-eutetóide e promoção da formação de bainita, Com teores entre $1.18 \% \mathrm{Cr}$ e $1.84 \% \mathrm{Cr}$ a microestrutura apresentou-se como longos grãos de ferrita ou bainita entre grãos pequenos e mais equiaxiais de ferrita. A porcentagem e comprimento desses grãos longos aumentaram juntamente com o teor de cromo.

\section{Influência do Molibidênio (Mo)}

$O$ efeito do molibidênio na microestrutura e nas propriedades de soldas de múltiplos passes feitas por eletrodo revestido variando-se o teor de $0 \%$ Mo a $1.1 \%$ Mo foi pesquisado por EVANS (1988). Para região do topo do cordão de solda, com aumento do teor de molibidênio houve reduçăo da porcentagem de ferrita primária até a sua quase completa eliminação com $1.1 \%$ Mo. A porcentagem de ferrita acicular inicialmente aumentou mas acima de $0.5 \%$ Mo houve diminuição da porcentagem de ferrita acicular com aumento da porcentagem de ferrita de segunda fase. A ferrita acicular refinou com o aumento de teor de molibidênio enquanto que a ferrita com segunda fase tornou-se mais grosseira.

\section{Influência do Cobre (Cu)}

HANNERZ (1988) analisou o efeito do cobre nas propriedades do metal de solda e concluiu que o cobre refinou a microestrutura secundária do metal de solda e teve uma tendência para formar fases como bainita em vez de ferrita pró-eutetóide. Em soldagens de alto aporte de calor alguns precipitados podem aparecer se o teor de cobre for alto. 
Segundo KLUKEN et al. (1994) a adição de cobre refinou a microestrutura e aumentou a porcentagem de ferrita de contorno de grão.

\section{Influência do Níquel (Ni)}

Segundo estudos de HARRISON \& FARRAR (1987) o Ni tem um efeito similar ao do Mn pois abaixa a temperatura de transformação no resfriamento, com a temperatura de início da formação da ferrita poligonal sendo abaixada mais do que temperatura de início da formação da ferrita acicular. Isto resultou em uma maior porcentagem de ferrita acicular às custas da ferrita poligonal.

TAYLOR \& EVANS apud FARRAR \& HARRISON (1987) relataram que com o aumento do teor de Ni houve diminuição da porcentagem de ferrita de contorno de grão e a ferrita acicular tornou-se mais refinada. Em por teores maiores que $3.5 \%$ em peso de $\mathrm{Ni}$ houve mudança na microestrutura com o desenvolvimento de martensita intragranular entre as ripas de ferrita.

\section{Influência do Titânio (Ti)}

O efeito desse elemento microligante no metal de solda de aços C-Mn foi investigado por Evans (1992). Com teores de até 30 ppm de Ti houve aumento de até dez vezes na fração de volume de ferrita acicular.

De acorda com SNYDER \& PENSE (1982) o efeito do Ti sobre a quantidade de veios de ferrita em cordões de solda de ARBL depende do teor de Mn. Quando o teor de Mn é baixo e o teor de Ti aumenta, a quantidade de veios de ferrita aumenta.

\section{Influência do Aluminio (Al)}

TERASHIMA \& HART (1984) verificaram o complexo efeito do Al na microestrutura e propriedades do metal de solda de aços C-Mn-Nb. O Al depende da basicidade do fluxo utilizado.

Para soldas feitas com fluxo básico (índice de basicidade $(\mathrm{IB})=2.0$ ) 0 aumento do Al primeiramente aumentou a porcentagem de ferrita acicular às 
custas de ferrita com M-A-C alinhados , mas com teores maiores que $0.016 \% \mathrm{Al}$ houve aumento da porcentagem de ferrita com M-A-C alinhados às custas da ferrita acicular.

Para soldas feitas com fluxo básico $(\mathrm{IB}=2.9)$ o aumento do teor de $\mathrm{Al}$ primeiramente aumentou a porcentagem de ferrita acicular às custas de ferrita com M-A-C alinhados, mas com teores maiores que $0.019 \%$ Al houve aumento da porcentagem de ferrita com M-A-C alinhados às custas de ferrita acicular.

Para soldas feitas com fluxo ácido $(\mathrm{IB}=0.9$ ) houve inicialmente aumento da ferrita acicular com aumento do teor de $\mathrm{Al}$, mas para teores maiores não houve mudanças claras na microestrutura

\section{Influência do Oxigênio $(\mathrm{O})$ e do Nitrogênio $(\mathrm{N})$}

Ambos elementos podem entrar no metal de solda por vários meios dependendo do processo de soldagem utilizado: diluição da chapa base, eletrodo, atmosfera, reações metal-escória e reações metal-gás.

O oxigênio está em maior quantidade presente no metal de solda como óxido ou inclusões resultantes das reações de desoxidação na poça de fusão.

Segundo BLAKE (1979) para teores extremamente baixos de O (200 ppm) há atraso na transformação $\gamma \rightarrow \alpha$, o que pode ser a causa da redução no número de núcleos. Pequenas adições de Ti ou teores de 0 acima de 250ppm há aumento do número de núcleos, levando a uma estrutura de ferrita fina.

Conforme ALHBLOM apud ABSON (1989) moderados teores de 0 favorecem a formação de fina ferrita acicular enquanto que altos teores de $\mathrm{O}$ favorecem a formação de uma estrutura de ferrita poligonal. Teores extremamente baixos de $O$ promovem a formação de grandes porções de ferrita com segunda fase alinhada.

LIU e OLSON (1986) verificaram que com o aumento do teor de $O$ no metal de solda, houve diminuição do tamanho médio das inclusões devido a maior freqüência de finas partículas com diâmetros menores que $0.1 \mu \mathrm{m}$. 
O nitrogênio em soldas feitas a arco submerso varia entre os teores de $0.004 \%$ a $0.014 \%$.

Segundo BLAKE (1979) há quatro maneiras pelas quais o $\mathrm{N}$ pode estar dissolvido no ferro: como moléculas, como átomos, como íons e como gás NO. Em metal de solda a baixa tenacidade associada ao $\mathrm{N}$ livre é atribuída ao endurecimento por solução sólida e aos efeitos de ancoramento das discordâncias e, para evitar isto adiciona-se elementos fixadores de $\mathrm{N}$ em nitretos tais como: $\mathrm{Mn}, \mathrm{Nb}, \mathrm{Cr}, \mathrm{V}, \mathrm{Al}, \mathrm{Ti}, \mathrm{Zr}$. Esses nitretos, durante o resfriamento impedem o crescimento do grăo austenítico e atuam como sítios de nucleação da ferrita.

$O$ efeito do $N$ foi estudado por LAU et al. (1988) em metal de solda feito por arco submerso e concluíram que quanto maior o teor de $\mathrm{N}$ menor a porcentagem de ferrita acicular e maior a de ferrita poligonal. Observaram também que aumentando-se $\mathrm{O}$ teor de $\mathrm{O}$ juntamente com $\mathrm{O}$ teor de $\mathrm{N}$ a porcentagem de ferrita poligonal dobra.

\section{Influência do Enxofre (S) e do Fósforo (P)}

Segundo estudos de EVANS \{1986) feitos com eletrodos revestidos variando-se o enxofre de $0,007 \%$ a $0.0046 \%$ e fósforo de $0,007 \%$ a $0,040 \%$, o enxofre é mais prejudicial do que o fósforo.

Com aumento do $\mathrm{S}$ houve aumento da porcentagem de ferrita com MAC alinhados e diminuição de aproximadamente de $45 \%$ na ferrita acicular atribuídos à existência de uma camada de MnS na superfície das inclusōes.

\subsection{4 - Inclusões não Metálicas}

As inclusões exercem um papel importante no desenvolvimento da microestrutura do metal de solda dos aços ARBL. É conhecido que as inclusões influenciam a transformação $\gamma-\alpha$ a restringindo o tamanho de grão da austenita e/ou fornecendo sítios favoráveis para a nucleaçắo dos vários microconstituintes. 
LIU e OLSON (1986) estudaram o papel das inclusões no controle da microestrutura de metal de solda de aços ARBL. Verificaram que soldas com alta porcentagem de ferrita acicular estavam associadas com grãos grosseiros de austenita anterior e com grande número de inclusões de diâmetro maior que $0.2 \mu \mathrm{m}$. Soldas com alta porcentagem de ferrita de contorno de grão estavam associadas com grãos finos de austenita anterior e com grande número de inclusões com diâmetro menor que $0.1 \mu \mathrm{m}$.

Conforme BARRITE et. al. (1982) uma maior densidade de inclusões e uma maior fração de volume de inclusões reduziu o tamanho da austenita anterior por ancoramento de contorno de grão, promovendo assim a nucleação em contorno de grão e impedindo a nucleação intragranular.

Segundo KAYALI et. al. (1983) inclusões que serviram como substrato para nucleação da ferrita acicular eram pequenas, menores que $1 \mu \mathrm{m}$ em tamanho, e eram arredondadas.

Nos estudos feitos por DOWLING et. al. (1986) não houve evidências para relacionar a porcentagem de ferrita acicular e as composições das fases das inclusões. Entretanto concluíram, segundo a teoria clássica da nucleação heterogênea, que as inclusões agem como substrato inerte para a nucleação de ferrita acicular.

\subsection{5 - Tamanho de Grão da Austenita Anterior}

É conhecido que a austenita de granulação grosseira decompõe-se mais lentamente comparada com austenita de granulação fina devido a menor área de contorno de grão disponivel para nuclear a ferrita.

Os estudos de HARRISON \& FARRAR (1987) mostraram que quanto menor o tamanho do grão da austenita anterior mais fácil foi a transformação para ferrita poligonal; enquanto que quanto maior o tamanho de grão da austenita anterior, a ferrita foi predominante.

Devido a fina granulação da austenita há uma alta densidade de favoráveis sítios primários de nucleação e uma alta taxa de nucleação nos 
contornos de grão ocorre para baixos superesfriamentos, assim a austenita decompõe-se em produtos de transformação de temperaturas altas como a ferrita poligonal. Grãos grosseiros formam poucos sítios primários que requerem considerável superesfriamento para se obter a mesma taxa de nucleação, assim o centro dos grãos austeníticos tornam-se favoráveis para a nucleação em sítios secundários, os quais resultam em produtos de transformação de temperaturas mais baixas como a ferrita acicular.

\section{6 - Influência da Microestrutura na Tenacidade}

Existe um crescente interesse na relação entre microestrutura e propriedades mecânicas com o objetivo de se desenvolver metais de solda com boas resistência e tenacidade. Este interesse não é surpresa, haja visto que é muito atrativo ser capaz de avaliar as propriedades mecânicas através da observação da microestrutura. Os fatores mais críticos que podem afetar a tenacidade do metal de solda são:
a) presença, tamanho e distribuição de inclusões;
b) tamanho de grão;
c) natureza e distribuição dos produtos de transformação microestruturais.

\subsection{1 - Inclusões}

Em certas aplicações, como vasos de pressão para usina nuclear, é necessário que o material ou metal de solda tenha alta resistência à fratura dúctil, isto ê, alto patamar de energia que causa a fratura dúctil. Nessa região a fratura ocorre pela coalescência de microporos e FARRAR (1974) observou que a resistência ao coalescimento de microporos é influenciada pela fração de volume, forma e distribuição de inclusões não-metálicas.

Segundo VAN DER BURG (1985) parece que a quantidade, a morfologia, o tipo e/ou a distribuição das inclusões disponiveis para iniciar o 
coalescimento de microporos influenciam mais do que a fração de volume no patamar de energia de fratura dúctil.

Como o conteúdo de inclusōes ê afetado pelo teor de oxigênio, as propriedades de impacto normalmente aumentam com a redução de oxigênio, quando os ensaios são realizados na região dúctil. Poucas inclusões produz crateras de grandes dimensões na superfície de fratura dúctil, por causa do menor número de inclusões disponíveis para coalescimento de microporos e isso acarreta um alto patamar de energia porque as mesmas estão associadas com alta absorção de energia.

Quanto ao patamar de energia que causa fratura frágil, TWEED e KNOT observaram que os sítios para iniciação da fratura frágil estão associadas às inclusões nao-metálicas. Eles desenvolveram um modelo envolvendo a deformação plástica da ferrita de contorno de grão, induzindo a fratura da inclusão e com o crescimento da trinca sob o efeito combinado do empilhamento.

Como a composição química é controlada pelas reações que ocorrem na poça da solda, conclui-se que uma microestrutura adequada e as propriedades mecânicas da solda só podem ser obtidas pela escolha correta dos consumiveis, os quais poderão minimizar o conteúdo de inclusões.

\subsection{2 - Tamanho de Grão}

De acordo com a equação (1) de Hall-Petch, a tensão de escoamento de um material é influenciada pelo seu tamanho de grão:

$\alpha_{0}=\alpha_{i}+k d^{-1 / 2}$

onde

$\alpha \mathrm{o}=$ tensão de escoamento

$\alpha_{i}=$ tensão de atrito que se opõe ao movimento de discordâncias

$\mathrm{k}$ = constante que representa uma medida da extensão do empilhamento de discordâncias nas barreiras

$d$ = diâmetro do grão 
A tensão de escoamento pode ser acrescida pelo aumento da tensão de atrito (trabalho à frio, endurecimento por solução sólida e por precipitação) ou pela diminuição do tamanho de grão. Aumentando-se a tensão de atrito haverá um aumento acentuado na temperatura de transição dúctil-frágil, mas diminuindo-se o tamanho de grão haverá redução na temperatura pelo fato dos contornos de grãos de alto ângulo inibirem a propagação da fratura por clivagem.

A influência do tamanho de grão na tenacidade do metal de solda foi estudada por ITO et al (1979), que relacionaram a temperatura de iniciação da trinca no ensaio COD para $\square_{c}=0,2 \mathrm{~mm}$ e a temperatura de transição do teste de impacto Charpy, com o diâmetro da ferrita e da bainita. Eles encontraram que a temperatura variava de forma crescente com 0 aumento de $\log d^{-1 / 2}$, onde d representa o tamanho médio do grão.

Como foi visto anteriormente, o tamanho de grão colunar pode ser reduzido pela adição de elementos de liga ou pelo rápido resfriamento durante a solidificação. Os elementos de liga que produzem grãos colunares pequenos , usualmente introduzirão algum endurecimento por solução sólida, que tenderão a contrapor o ganho em ductilidade e tenacidade obtido com o refino da microestrutura.

Supondo que o conteúdo de inclusões esteja em, um nível aceitável, o meio mais prático de melhorar a tenacidade é favorecer um produto final de transformação com, uma boa tenacidade, para isto necessita-se de um produto com tamanho de grão pequeno e contornos de alto ângulo.

\subsection{3 - Produtos de Transformação}

A resistência à clivagem e a temperatura de transição são controladas pelos vários constituintes microestruturais, pelo tamanho das colônias e pela sua proporção no metal de solda. Como existe uma grande variedade de produtos de transformação, os mesmos podem apresentar propriedades 
mecânicas diferenciadas, além disso cada constituinte da estrutura secundária tem sua própria influência sobre a tenacidade.

A ferrita de contorno de grão e a ferrita poligonal são normalmente consideradas prejudiciais a tenacidade por causa de sua granulação grosseira. Através de inúmeras pesquisas parece que as trincas no metal de solda de aço ferrítico normalmente se propaga ao longo da ferrita de contorno de grão, um processo que é intensificado pela presença da perlita ao longo dos contornos.

A ferrita com fase secundária alinhada é também considerada prejudicial á tenacidade. Isto está relacionado com a presença de carbetos, austenita retida e martensita ao longo das placas de ferrita.

A presença de perlita é sempre considerada adversa à tenacidade, particularmente quando as lamelas de cementita estão alinhadas na direção da trinca. Parece que a temperatura de transição dúctil-frágil aumenta mais ou menos linearmente com o aumento da quantidade de perlita. entretanto, uma diminuição da espessura da lamela de cementita é benéfica à tenacidade porque os carbetos mais finos são mais adequados para deformar do que trincar sob tensão.

A bainita é usualmente descrita como tendo duas morfologias com diferenças microestruturais: a bainita superior e a inferior. A temperatura de transição dúctil-frágil da bainita superior é alta porque a fratura por clivagem pode propagar nas películas de cementita. A bainita inferior possui uma fina dispersão de carbetos que impedem a propagação da fratura, deformando plasticamente ao invés de fraturarem. A martensita e a austenita retida também são prejudiciais à tenacidade.

A ferrita acicular pode ser considerada como um constituinte que melhor promove a tenacidade. Em geral, a temperatura de transição diminui linearmente com a quantidade de ferrita acicular. A influência favorável desse constituinte ê primeiramente causada pelo tamanho de grão muito pequeno, além disso, a ferrita acicular é caracterizada por uma adequada densidade de discordâncias e por ausência de formaçao de maclas, as quais ocasionam 
uma deformação plástica ao invés de fraturar por clivagem. A chance de uma fratura por clivagem é reduzida ainda mais pela presença de contornos de alto ângulo entre as ripas, os quais impedem a propagação da trinca.

Embora a ferrita seja um microconstituinte de grande importância para promover uma alta tenacidade, WIDGERY mostrou evidências que depósitos com muito baixa tensão de escoamento, contendo principalmente ferrita de contorno de grão, ferrita de placas laterais e bainita podem ter alta resistência â clivagem e muito baixa temperatura de transição no ensaio de COD. Porém, material desse tipo pode ser difícil de se obter na prática.

Como já foi mencionado anteriormente, no metal de solda existe uma tendência para iniciação da fratura por clivagem nas ferritas de contorno de grão, na ferrita de placas laterais e ou nas regiões de bainita superior por causa da concentração de tensão e do tamanho dessas fases. Quando ocorre o aumento dá quantidade de ferrita acicular com redução das fases acima mencionadas, pode resultar em um aumento da tenacidade. Isso pode ser obtido pela redução do aporte de calor elou pelo aumento de elementos de liga, tais como: $\mathrm{Mn}$, Mo e $\mathrm{Ni}$, resultando em uma melhor resistência à clivagem, como foi sugerido por DOLBY na figura 3.4. Para uma proporção muito alta de ferrita acicular (> 90\%) existe uma tendência de redução da tenacidade devido a formação de martensita e a um aumento da tensão de escoamento causado pelo endurecimento por solução sólida.

HARRISON e FARRAR utilizando curvas de resfriamento continuo (CRC) para metais de solda de aços C-Mn e C-Mn-Ni obtidos na soldagem com eletrodos revestidos, observaram que uma alta porcentagem de ferrita acicular é favorável para a tenacidade. Que a presença de uma quantidade substancial de regiōes com microfases martensita e ou perlita entre as ripas de ferrita acicular foi prejudicial à tenacidade, pois essas microfases podem atuar como sítios para iniciação da fratura por clivagem. Esses mesmos pesquisadores, concluíram que a melhor combinação de propriedades mecânicas pode ser obtida quando a quantidade de ferrita acicular for maior do que $65 \%$ e seu tamanho médio de aproximadamente 1. 


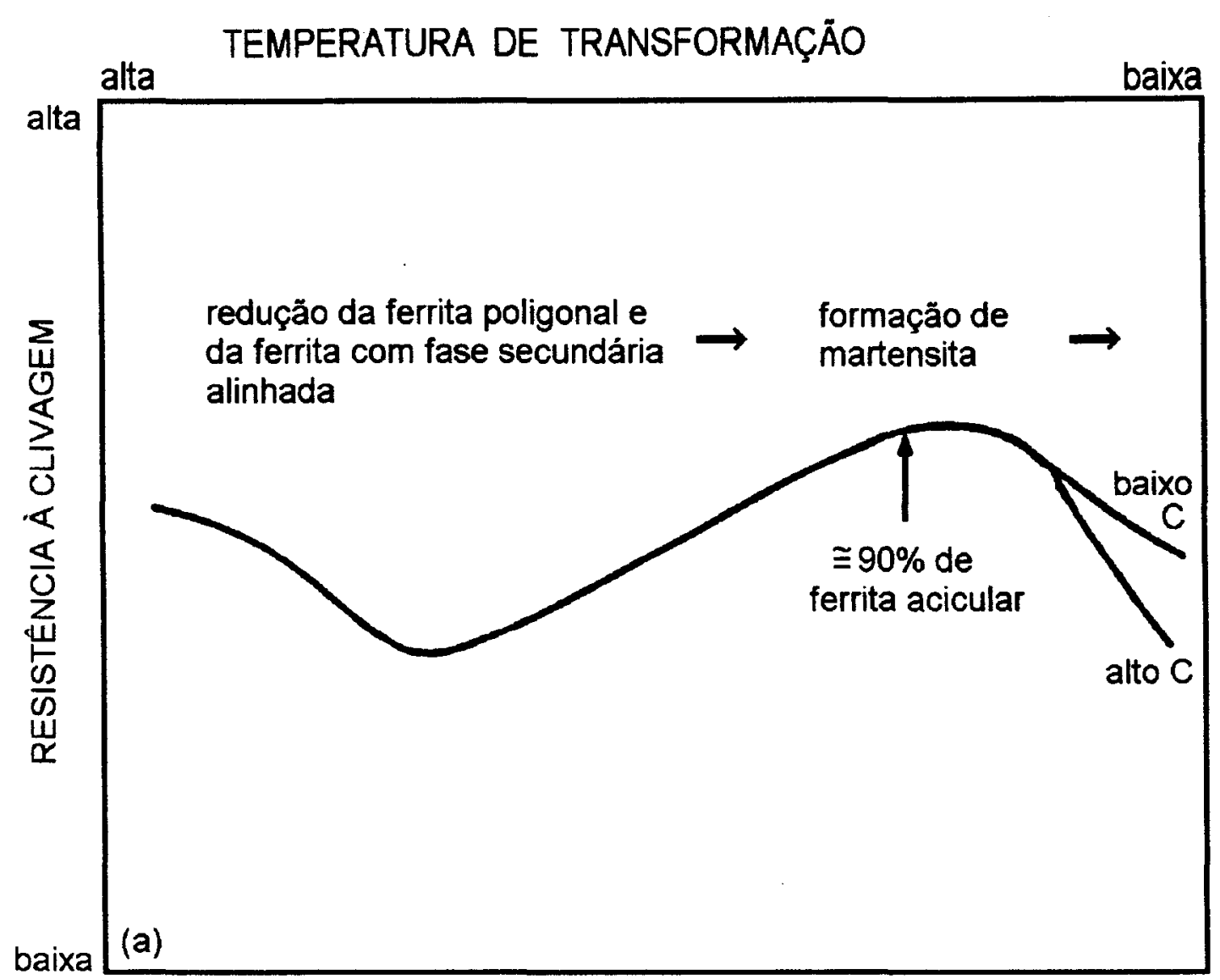

AUMENTO DA FERRITA ACICULAR E TENSẢO DE ESCOAMENTO

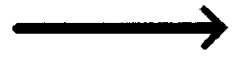

Figura 3.4 - Resistência à clivagem em função do teor de ferrita acicular e da tensão de escoamento

\section{7 - Efeitos do tratamento térmico pós-soldagem}

Ao nível de propósitos o tratamento térmico pós-soldagem pode ser distinguido entre a aplicação realizada com a finalidade de reaustenitizar o metal de solda e aquela que visa somente reveni-lo ou, de uma forma mais ampla, diminuir a intensidade das tensões residuais desenvolvidas na junta soldada como um todo. Na primeira aplicação o tratamento térmico póssoldagem tem sido denominado de intercrítico, enquanto que na segunda a designação de tratamento térmico de alivio de tensões é também comumente usada. Independentemente do propósito da aplicação, efeitos microestruturais 
são produzidos no metal de solda e a magnitude desses efeitos variam acentuadamente com os parâmetros operacionais utilizados no tratamento (velocidades de aquecimento e resfriamento, temperatura de tratamento e o tempo de exposição à temperatura de tratamento), além da composição química participante do metal de solda (JARMAN et ali (1985); STOUT (1985)).

Sem dúvida que a maior parte dos trabalhos sobre tratamento térmico pós-soldagem se concentram na averiguação dos efeitos do alívio de tensões nas propriedades mecânicas e entre eles são também relevantes para os objetivos do presente trabalho aqueles que associam as constatações com a decomposição das microfases ou, ainda, a formação de outras segundas fases. Alguns desses trabalhos serão considerados a seguir.

Embora quase todos os trabalhos de Evans apresentados no item precedente contenham também informações sobre os efeitos microestruturais do tratamento térmico de alívio de tensões, constatações mais completas em termos da decomposição das microfases do tipo M-A, ou mesmo a formação de outras segundas fases, foram fornecidas em outros dois trabalhos feitos por esse pesquisador, ambos constituindo-se em uma total continuidade com respeito aos materiais e métodos que os anteriores, particularmente em relação às influências do manganês e do carbono no desenvolvimento microestrutural do metal de solda.

O primeiro desses dois trabalhos (EVANS, 1985) envolveu em seu objetivo principal o estudo dos efeitos da normalização a $930{ }^{\circ} \mathrm{C}$ por 30 minutos, seguida ou não do revenimento a $580{ }^{\circ} \mathrm{C}$ por 2 horas, na microestrutura e tenacidade ao impacto de metais de solda com composiçōes químicas correspondente ao último passe idênticas às obtidas no estudo já relatado da influência do aumento no teor de manganês no desenvolvimento microestrutural em metais de solda apenas na condição como soldado.

Os exames metalográficos realizados mostraram que nas duas condições de tratamentos térmicos pós-soldagem a microestrutura dos metais de solda consistiu de grãos de ferrita primária poligonal com a incidência de 
segundas fases. De uma forma mais específica, foi observado que nos metais de solda somente normalizados a quantidade total de segundas fases, distinguidas como camadas contínuas e finas de cementita localizadas nos contornos de grãos, perlita e as microfases martensita - austenita retida bainita (M-A-B), aumentou com o aumento no teor de manganês.

Além disso, em termos de quantidade relativa, foi constatada a sua dependência com o teor de manganês, sendo predominante os filmes de cementita nos contornos de grãos para teores de $0,6 \%$ de manganês, mudando para uma maior quantidade de perlita para teores maiores desse elemento e culminando com a grande incidência das microfases (M-A-B) para o teor de 1,8\% de manganês. Após o revenimento dos metais de solda, até teores intermediários de manganês foi observada a degenerasção parcial da perlita e a tendência dos filmes de cementita em se globalizarem. Com o teor de mais elevado de manganês foi observada a decomposição das microfases (M-A-B) formando partículas finas de carbonetos dentro das próprias regiões que as continham.

No comportamento da tenacidade ao impacto, avaliada por ensaio Charpy, os resultados alcançados permitiram constatar que para os metais de solda somente normalizados o aumento no teor de manganês foi presumivelmente atribuido aos efeitos combinados do refinamento microestrutural causado pelo manganês e a eliminação dos filmes decementita posicionados nos contornos de grãos. Para o teor de 1,8\%, entretanto, o comportamento foi interpretado como uma conseqüência da compensação de tal refinamento microestrutural pela maior incidência das microfases (M-A-B). Com o subsequente revenimento dos metais de solda foi detectada uma melhora geral na tenacidade ao impacto, porém também dependente do teor de manganês, isto é, significativa para o teor de $1,8 \%$ de manganês e limitada para teores mais baixos. Essa diferença foi explicada pelo fato da formação dos glóbulos de cementita nos contornos de grãos serem menos benéficos do que a presença da perlita degenerada e a decomposição das microfases (M-A-B). 
No outro trabalho citado (EVANS,1986 (b)) observa-se também que a idéia fundamental foi a busca de informações complementares a respeito do tratamento térmico pós-soldagem (no caso convenientemente denominado de alívio de tensőes) na incidência de segundas fases em metais de solda com as mesmas composições químicas do último passe que às obtidas no trabalho que investigou a influência do aumento do teor de carbono relatado anteriormente.

Os principais parâmetros operacionais utilizados no tratamento térmico foram a temperatura de $580{ }^{\circ} \mathrm{C}$ e o tempo de exposição de 2 horas nessa temperatura. As análises metalográficas realizadas mostraram que de uma forma geral ocorreu a decomposição das microfases M-A em ferrita e carbonetos, além da esferoidização dos filmes de cementita nos contomos de grãos e das colônias de perlita. A resposta dessa alteração microestrutural considerando a resistência mecânica, foi refletida pelo acentuado decréscimo nessa propriedade, atribuído principalmente ao amolecimento da matriz ferrítica. A tenacidade ao impacto melhorou com baixos teores de carbono e manganês, e deteriorou-se com a combinação de teores elevados de ambos. Esse comportamento foi explicado simplesmente pela maior ocorrencia de partículas de cementita precipitadas nos contornos de grãos para essa última condição de composição química

Observações microestruturais bem semelhantes às feitas por Evans nos dois trabalhos relatados nos parágrafos anteriores também foram feitas por KONKOL (1988) quando investigou os efeitos da temperatura e tempo do tratamento térmico de pós-soldagem na microestrutura do último passe em metal de solda obtido pelo processo a arco submerso convencional e depositado em junta de aço estrutural ASTM A 36. As temperaturas utilizadas foram de 593 e $648^{\circ} \mathrm{C}$ para os tempos de tratamento de 5 e 100 horas. $\mathrm{Na}$ condição como soldada a microestrutura resultante no metal de solda foi identificada como ferrítica em natureza, englobando a ferrita proeutetóide, ferrita acicular e a ferrita com a incidência de segundas fases alinhadas (martensita, austenita retida ou carbonetos). Com a aplicação do tratamento 
térmico pós-soldagem, particularmente na combinação de maior temperatura e maior tempo, foi observada a esferoidização dos carbonetos presentes. Em termos experimentais, essa observação foi feita por microscopia ótica em amostras preparadas com reativo superpicral.

NOVAES GOMES et ali (1993) estudaram os efeitos do tratamento térmico de alívio de tensões nas propriedades mecânicas de metais de solda com diferentes temperabilidades. As soldas foram realizadas pelo processo a arco submerso em passe único e envolveram a adição de pó metálico. A variação na temperabilidade dos metais de solda foi alcançada pela utilização de dois eletrodos diferenciados com respeito aos teores de cromo e manganês, assim como pela adição de duas diferentes quantidades de pó metálico para cada um dos eletrodos usados. $O$ aporte de calor utilizado foi ajustado de acordo com as quantidades adicionadas de pó metálico.

Como parâmetros operacionais do tratamento térmico de alívio de tensões foram utilizados a temperatura de $580^{\circ} \mathrm{C}$, tempo de permanência de 1 hora, com o resfriamento sendo realizado em duas etapas: ao forno até a temperatura de $400{ }^{\circ} \mathrm{C}$ e ao ar até a temperatura ambiente. As propriedades mecânicas investigadas foram a dureza, a resistência mecânica e a tenacidade ao impacto, avaliada através da determinação da temperatura de transição 50\% dúctil - 50\% frágil. A partir da comparação dos valores obtidos dessas propriedades para os metais de solda na condiçăo como soldados e na condição como tratados termicamente, verificou-se que nos metais de solda de alta temperabilidade a dureza aumentou, enquanto que nos de baixa temperabilidade houve uma redução nos valores das medidas de dureza.

O aumento nos valores das medidas de dureza foi atribuído à sobreposição do efeito do endurecimento por solução sólida com o elemento cromo, oriundo de uma possível decomposição de carbonetos, em relação ao efeito da acomodação do reticulado causado pelo alívio das tensões residuais. A resistência mecânica aumentou em todos os metais de solda tratados, detectando-se aumentos maiores nos metais de solda com temperabilidades maiores. O referido efeito do endurecimento por solução sólida também 
explicou o aumento na resistência mecânica. A tenacidade ao impacto aumentou em todos os metais de solda tratados, porém nos metais de solda de mais baixas temperabilidades os aumentos foram mais significativos. Para - comportamento global da tenacidade, além da redução nas tensões internas, a discussão envolveu outros efeitos microestruturais causados pelo tratamento térmico realizado, como a ocorrência da esferoidização dos carbonetos remanescentes e a decomposição das microfases.

Uma interessante investigação foi feita por COSTA et alii (1995) sobre a influência da aplicação de múltiplos tratamentos térmicos de alivio de tensões na tenacidade ao impacto de metal de solda obtido em múltiplos passes, confeccionado por soldagem manual com eletrodo revestido e depositado sobre juntas de aço ARBL temperado e revenido. Em linhas gerais, o procedimento para a realização dos referidos tratamentos seguiu a norma AWS D1.1/91 e consistiu da aplicação sucessiva de vários ciclos térmicos com duração de 2 horas a temperatura de $590^{\circ} \mathrm{C}$. A partir da análise dos resultados apresentados da energia absorvida nas temperaturas de ensaio de -30 e $-40{ }^{\circ} \mathrm{C}$ em função do número de ciclos aplicados, constatouse uma redução de até $40 \%$ nos valores da energia absorvida após sete aplicaçōes sucessivas do ciclo térmico. Essa fragilidade foi creditada tanto ao aumento na precipitação de cementita, a partir da decomposição da austenita retida, quanto pelo coalescimento da mesma, nesse caso, como uma conseqüência da temperatura de tratamento utilizada.

A análise dos trabalhos sobre os efeitos do tratamento térmico póssoldagem apresentados até então, reafirmaram, conforme comentado inicialmente, a dependência da intensidade dos efeitos microestruturais com a composição química participante do metal de solda e de alguns dos valores típicos dos parâmetros operacionais do tratamento, nominalmente a temperatura e o tempo. Também é aparente que esses efeitos são praticamente restritos principalmente à possível decomposição da austenita retida, ou de outra forma, as microfases do tipo M-A, em ferrita e carbonetos, mais a própria acomodação do reticulado cristalino por efeito da relaxação das 
tensões residuais. Uma outra conseqüência que pode influir negativamente na tenacidade do metal de solda tratado termicamente é a fragilização de revenido. Tal ocorrência foi recentemente abordada por SHIGA et ali (1996) quando consideraram o trabalho de WATANABE e KOJIMA (1981) como parte da revisão sobre os efeitos do tratamento térmico pós-soldagem nas propriedades mecânicas de metais de solda depositados em uma grande variedade de aços. Mais especificamente, nesse trabalho revisado, concernente às relações entre a variação do teor de nióbio e a tenacidade ao impacto em metais de solda obtidos pela soldagem MIG (Metal Inert Gas), em passe único e aporte de calor de $2,4 \mathrm{kj} / \mathrm{mm}$, foi relatado que a tenacidade ao impacto dos metais de solda apresentaram a tendência de redução não somente pelo aumento do teor de nióbio, mas também pelas duas velocidades de resfriamento usadas no tratamento, ao ar e no ambiente do forno. Essa degradação da tenacidade ao impacto após o tratamento térmico foi explicada pela ocorrência da fragilização de revenido, principalmente para o resfriamento mais lento, ou seja, ao forno.

Como é sabido a ocorrência desse fenômeno está intimamente relacionado à segregação de átomos de impurezas nos contornos de grãos e, portanto, também concernente com teor de manganês do metal de solda. Sob esse ponto de vista, o autor comenta ainda em relação ao trabalho revisado o fato de que para metais de solda com teor de nióbio de $0,03 \%$ e variados teores de manganês a tenacidade após o tratamento térmico com resfriamento tanto ao ar, quanto ao forno, diminuiu com o aumento do teor de manganês. 


\section{4 - MATERIAIS E MÉTODOS}

\section{1 - Materiais}

Foram utilizados para este trabalho os seguintes consumiveis:

- chapa base : aço ARBL USI-SAC-50 resistente à corrosão atmosférica;

- eletrodos : EM-12K e EB-2 (classificação AWS);

- fluxos: OK-1071 e BX-200

- pó metálico : PD-3

As composições químicas dos consumíveis são dadas nas tabelas a seguir .

TABELA 4.1: Composições Químicas (\% peso-Fe balanceado)

\begin{tabular}{ccccc}
\cline { 2 - 5 } & $\begin{array}{c}\text { Chapa } \\
\text { Base }\end{array}$ & $\begin{array}{c}\text { Pó } \\
\text { Metálico }\end{array}$ & $\begin{array}{c}\text { Arame } \\
\text { EB-2 }\end{array}$ & $\begin{array}{c}\text { Arame } \\
\text { EM-12K }\end{array}$ \\
\hline $\mathbf{C}$ & 0,105 & 0,150 & 0,094 & 0,110 \\
$\mathbf{S i}$ & 0,441 & 0,080 & 0,224 & 0,270 \\
$\mathbf{M n}$ & 1,279 & 1,940 & 0,587 & 1,110 \\
$\mathbf{P}$ & 0,047 & 0,003 & 0,045 & 0,020 \\
$\mathbf{S}$ & 0,010 & 0,010 & 0,005 & 0,010 \\
$\mathbf{C r}$ & 0,428 & 0,040 & 1,280 & 0,020 \\
$\mathbf{N i}$ & 0,145 & - & 0,128 & 0,012 \\
$\mathbf{M o}$ & 0,016 & 0,003 & 0,492 & - \\
$\mathbf{C u}$ & 0,340 & - & 0,090 & 0,020 \\
$\mathbf{A l}$ & 0,016 & - & 0,054 & - \\
\hline
\end{tabular}

TABELA 4.2: Composição Química dos Fluxos (\% peso aproximada)

\begin{tabular}{ccc}
\hline Composição & OK-1071 & BX-200 \\
\hline $\mathrm{SiO}_{2}+\mathrm{TiO}_{2}$ & 10 & 20 \\
$\mathrm{CaO}+\mathrm{MgO}$ & 35 & 27 \\
$\mathrm{Al}_{2} \mathrm{O}_{3}+\mathrm{MnO}_{\mathrm{CaF}_{2}}$ & 40 & 40 \\
\hline
\end{tabular}




\section{2- Métodos}

\subsection{1 - Procedimentos de soldagem}

Dezesseis chapas foram usinadas, sendo duas chapas de cada condição, para que posteriormente uma de cada condição sofresse o tratamento pós soldagem. Foram utilizados dois tipos de eletrodos, dois tipos de fluxos, e dois aportes de calor, totalizando as oito combinações de consumíveis de soldagem.

Todo procedimento de soldagem, inclusive quanto a limpeza das chapas e da máquina foi seguido de maneira a garantir uma solda sem defeitos.

\section{USINAGEM}

Chapas de aço foram cortadas nas dimensões $560 \times 164 \times 25,4 \mathrm{~mm}$, sendo que seu comprimento foi cortado no sentido paralelo ao da laminaçăo da chapa. As chapas foram inicialmente aplainadas para correção do perfil, posteriormente com utilização de um bedame foi usinado o chanfro em " $\mathrm{V}$ ", ao longo de seu comprimento, no centro de sua largura, com seu vértice formando uma base plana. A figura 4.1 mostra as dimensões do chanfro.

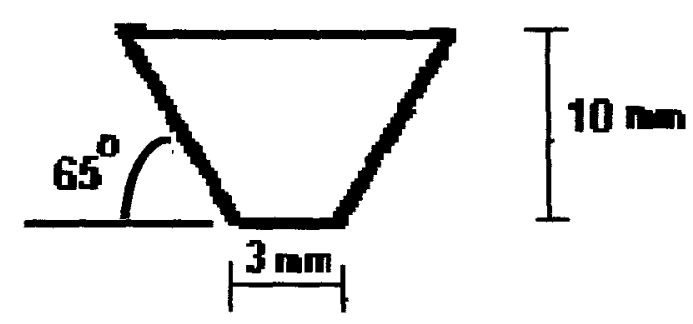

Figura 4.1 - Dimensões do chanfro da chapa base. 


\section{SOLDAGEM}

$O$ equipamento utilizado na soldagem foi uma máquina $B A M B O Z Z I$ do tipo transformador-retificador com característica estática de tensão constante, modelo TRR-3600, 600 A, 40 V e 36 KVA a $100 \%$.

As soldagens foram executadas em corrente contínua e polaridade positiva, com a extensão do eletrodo de $32 \mathrm{~mm}$, em um único passe e sem pré aquecimento. A adição de pó metálico no chanfro foi realizado por gravidade através de um dispositivo como pode ser visto na figura 4.2 .

As chapas foram soldadas através do processo arco submerso com adição de pó metálico, utilizando-se os parâmetros de soldagem dados na tabela 4.3.

TABELA 4.3: Condições de Soldagem

\begin{tabular}{llrl}
\hline Tensão & Corrente & $\begin{array}{r}\text { Veloc. de } \\
\text { Soldagem }\end{array}$ & $\begin{array}{c}\text { Aportes de } \\
\text { Calor }\end{array}$ \\
$34 \mathrm{~V}$ & $660 \mathrm{~A}$ & $28,80 \mathrm{~cm} / \mathrm{min}$ & $4,80 \mathrm{~kJ} / \mathrm{mm}$ \\
$34 \mathrm{~V}$ & $660 \mathrm{~A}$ & $38,20 \mathrm{~cm} / \mathrm{min}$ & $3,60 \mathrm{~kJ} / \mathrm{mm}$ \\
\hline
\end{tabular}

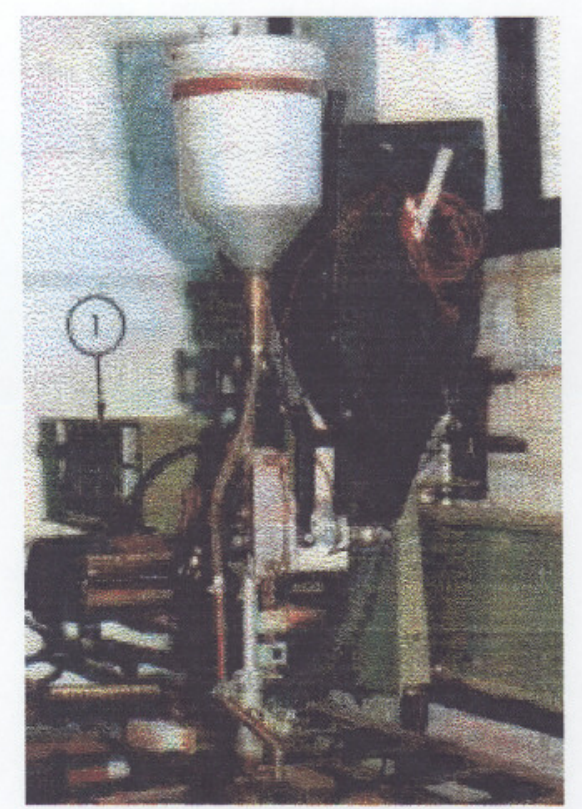

Figura 4.2 - Equipamento utilizado na soldagem com dispositivo dosador de pó metálico 
A máquina, as chapas e os "mata-juntas" foram rigorosamente limpos para evitar contaminações. A voltagem e a amperagem foram controladas por voltímetro e amperímetro acoplados ao equipamento.

Após a soldagem as chapas foram identificadas e marcadas conforme a tabela 4.4 .

TABELA 4.4: Identificação das chapas

\begin{tabular}{|c|c|c|c|}
\hline Código & eletrodo & fluxo & aporte de calor \\
\hline $1 \mathrm{p3}$ & EB-2 & BX-200 & 4,8 \\
\hline $1 \mathrm{p} 2$ & EB-2 & BX-200 & 4,8 \\
\hline $2 \mathrm{p3}$ & EB-2 & OK-1071 & 4,8 \\
\hline $2 \mathrm{p} 2$ & EB-2 & OK-1071 & 4,8 \\
\hline $3 p 3$ & EM-12K & BX-200 & 4,8 \\
\hline $3 p 2$ & EM-12K & BX-200 & 4,8 \\
\hline $4 p 3$ & EM-12K & OK-1071 & 4,8 \\
\hline $4 \mathrm{p} 2$ & EM-12K & OK-1071 & 4,8 \\
\hline $5 p 1$ & $\mathrm{EM}-12 \mathrm{~K}$ & OK-1071 & 3,6 \\
\hline $5 p 2$ & EM-12K & OK-1071 & 3,6 \\
\hline $6 \mathrm{p} 1$ & EM-12K & BX-200 & 3,6 \\
\hline $6 \mathrm{p} 2$ & $\mathrm{EM}-12 \mathrm{~K}$ & BX-200 & 3,6 \\
\hline $7 \mathrm{p} 1$ & EB-2 & BX-200 & 3,6 \\
\hline $7 p 2$ & EB-2 & BX-200 & 3,6 \\
\hline $8 p 1$ & EB-2 & OK-1071 & 3,6 \\
\hline $8 p 2$ & EB-2 & OK-1071 & 3,6 \\
\hline
\end{tabular}

( As amostras com índice 2, foram tratadas termicamente após a soldagem )

\section{Tratamento Térmico Pós-Soldagem}

Após a soldagem, uma chapa de cada composição sofreu um tratamento térmico de alívio de tensões que constituiu no aquecimento das chapas a $580^{\circ} \mathrm{C}$ por uma hora com posterior resfriamento no forno. 


\subsection{2 - Análises Químicas}

Foram retiradas amostras dos cordōes de solda para análise química. Os teores de carbono e enxofre foram determinados pelo processo de fusão em atmosfera de oxigênio e os teores de oxigênio e nitrogênio pelo processo de fusão a vácuo. Os demais elementos foram determinados por espectrometria de plasma.

As amostras para análise química após cortadas na serra, foram cortadas no "cut-off" nas dimensões de uma polegada quadrada, na região do cordão de solda, conforme a figura 4.3.

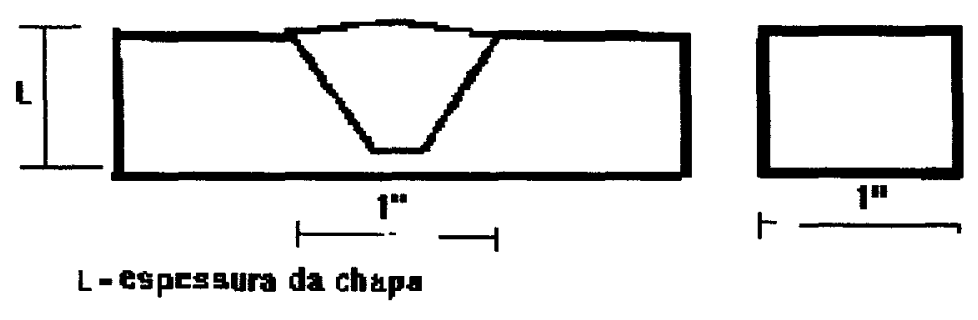

Figura 4.3: Amostra para análise química

\subsection{3 - Metalografia}

O estudo metalográfico foi realizado através de exames macro e micrográficos e os corpos de prova foram retirados da chapa base mediante um corte transversal em relação ao cordão de solda.

A macrografia do cordão de solda foi feita com o intuito de caracterizar a diluição do metal de base, sendo que a preparação do corpo de prova foi realizada segundo o método convencional, com polimento final efetuado com alumina de $1 \mu \mathrm{m}$. $O$ ataque químico para revelação da macroestrutura foi feita com uma mistura de $85 \mathrm{ml}$ de água, $5 \mathrm{ml}$ de etanol e $15 \mathrm{ml}$ de ácido nítrico.

A avaliação da diluição da chapa base foi realizada através da análise comparativa de áreas, por pesagens dos recortes das macrografias, com relação à área do chanfro. 
As amostras para as análises micrográficas foram preparadas de forma tradicional, lixadas até lixa $600 \mathrm{com}$ posterior pré-polimento em óxido de cromo e polimento final em pasta de diamante de $1 \mu \mathrm{m}$ e ataque com NITAL $3 \%$. Para se caracterizar e quantificar a microestrutura foi realizado um trabalho meticuloso segundo método proposto pelo IIW. Para análise quantitativa utilizou-se um aumento de 500X, em microscópio ótico LEICA, modelo METALLOVERT, com superposição de uma malha quadriculada para contagem das estruturas.

Para verificar a formação das microfases nos contornos das ferritas foi realizada uma análise da microestrutura através da técnica de metalografia colorida. As amostras foram atacadas com NITAL $2 \%$ e posteriormente foi realizado um tingimento colorido com reagente de KLEMM II. Esse ataque se mostrou muito sensivel, tanto ao tempo de exposição quanto à temperatura (ambiente e do reagente), o que se pode observar pelas diferentes colorações conseguidas nas amostras, contudo isso não prejudicou a contagem das microfases já que a microfase MA, de interesse, se mostrou branca, ou seja , não foi tingida pelo reagente.

Após o ataque, as amostras foram fotografadas com aumento de 2000X. As fotomicrografias foram então superpostas por transparências, as microfases coloridas com tinta preta para realçar o contraste e então essas transparências foram escaneadas e tratadas num programa de análise de imagens para determinação de sua porcentagem em área.

\subsection{4 - Ensaios Mecânicos}

\section{Dureza}

As medidas de dureza foram obtidas através de máquina Vickers de impressão piramidal conforme norma ASTM E 92-82, fez-se cinco medidas e calculou-se a média das cinco medidas. A carga utilizada foi de $10 \mathrm{~kg}$ e a disposição das cinco impressões na amostra são mostradas pela figura 4.4. 


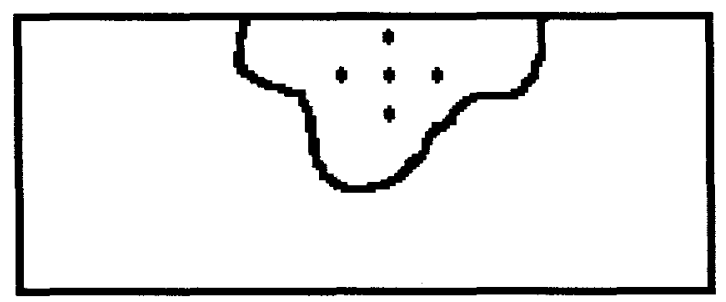

Figura 4.4 - Disposição das medidas de dureza.

Tração

Após o corte das chapas, 2 amostras de cada chapa para ensaio de tração foram usinadas conforme a figura 4.5 na direção longitudinal ao cordão de solda, conforme a figura 4.6 .

Os ensaios de tração foram realizados em máquina INSTRON modelo TT-DM-L . Foram ensaiados corpos de prova segundo norma B.S. 709:1983. de cada chapa na direção longitudinal na temperatura de $-10^{\circ} \mathrm{C}$. Os resultados apresentados são a média de dois ensaios para cada amostra.

A escolha da temperatura de $-10^{\circ} \mathrm{C}$ foi motivada pela observação das aplicações práticas. Como exemplo pode-se citar a construção de plataformas marítimas para exploração de petróleo.

Os ensaios a $-10^{\circ} \mathrm{C}$ foram realizados com os corpos de prova no interior de uma câmara de temperatura controlada acoplada à máquina INSTRON, como mostra a figura 4.7.

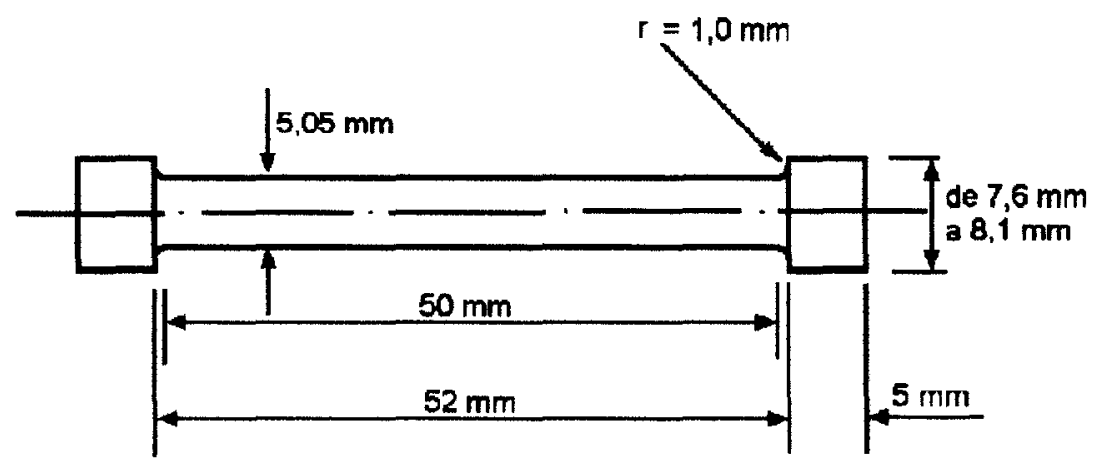

Figura 4.5 - Corpo de Prova para ensaio de tração. 


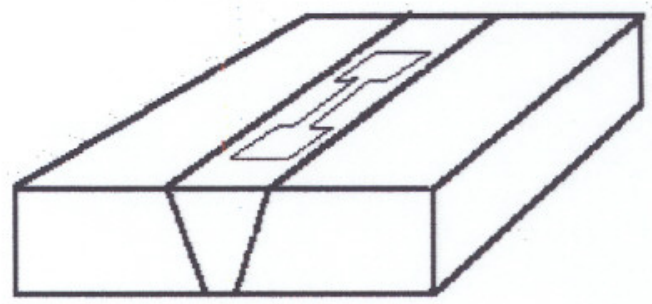

Figura 4.6 - Posição dos corpos de prova em relação à solda.

A temperatura do corpo de prova foi mantida a $-10^{\circ} \mathrm{C}$ através de nitrogênio líquido por um dispositivo e monitorada através de termopar como mostrado na figura 4.7 .
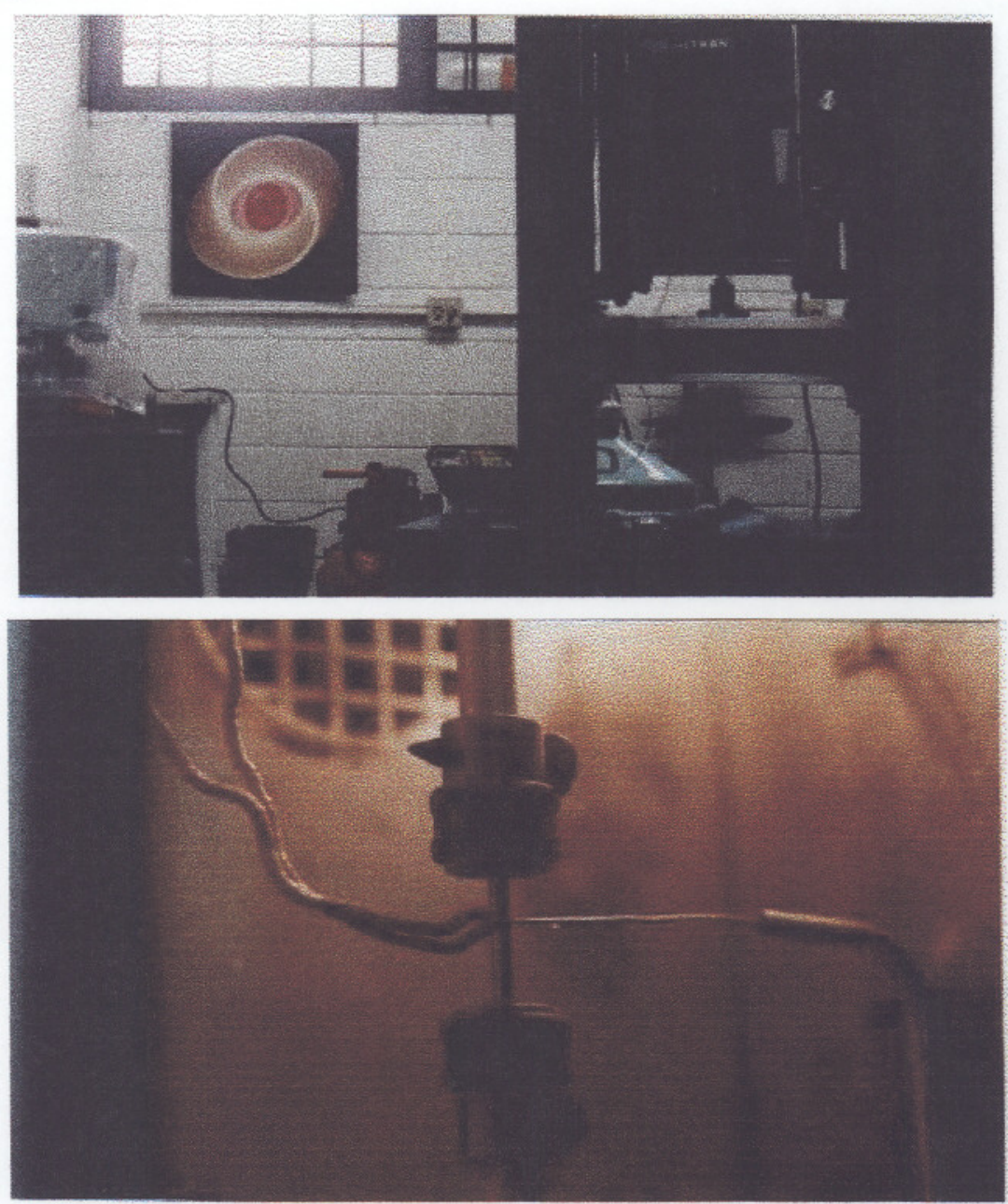

Figura 4.7 - Dispositivo para ensaio de tração a $-10^{\circ} \mathrm{C}$.

Com as medidas de comprimento e diâmetro, iniciais e finais, mais as cargas de escoamento e máxima, foram calculados: alongamento $(E)$, redução de área $(A)$, limite de escoamento $\left(\sigma_{e}\right)$ e limite de resistência $\left(\sigma_{r}\right)$. 


\section{Impacto Charpy}

No ensaio de impacto Charpy foram utilizados corpos de prova do tipo A (entalhe em " $V$ ") segundo a norma ASTM E-23-86. Para cada solda retirouse em média 10 corpos de prova, sendo que todos foram aplainados e retificados cuidadosamente de tal modo que as dimensões permanecem dentro das tolerâncias da norma.

Com o objetivo de localizar o chanfro no centro da solda e normal a espessura da chapa, foi feito um polimento nos mesmos com posterior ataque de Nital $5 \%$. Após a localização do entalhe, foi efetuada a usinagem em uma fresadora. Os ensaios foram executados em uma máquina de impacto Amsler com capacidade de $350 \mathrm{~J}$, no intervalo de temperatura de -60 a $+80^{\circ} \mathrm{C}$, variando-se de 20 em 20 graus, para controle da temperatura utilizou-se nitrogênio líquido no caso das temperaturas sub-zero e banho quente nas temperaturas acima da ambiente. Nos dois casos os corpos de prova foram mantidos tempo suficiente sob a temperatura para homogeneização da mesma. A avaliação das áreas dúctil e frágil foi feita de acordo com a norma acima mencionada.

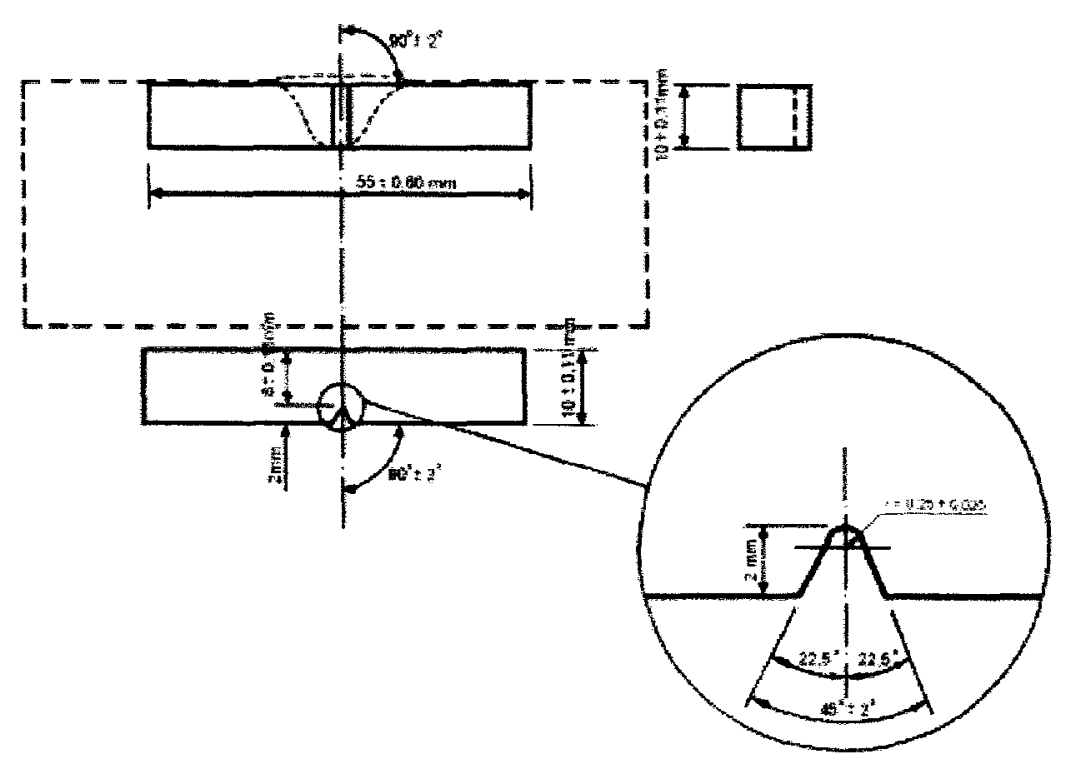

Figura 4.8 - Corpo de Prova para ensaio Charpy 


\section{CTOD}

O ensaio de CTOD foi realizado nos corpos de prova 5P1 e 7P1, os dois cordões nos quais a austenita retida foi eliminada após o tratamento térmico, e que apresentaram as propriedades mecânicas mais adequadas. $A$ temperatura de ensaio foi de $-10^{\circ} \mathrm{C}$. Os corpos de prova para o ensaio de CTOD foram usinados conforme a norma BS 7448:1991. Após a usinagem os corpos de prova foram polidos e marcadas as referências para o controle do tamanho da pré-trinca por fadiga, sendo que a trinca foi obtida em uma máquina universal de ensaio da marca MTS com capacidade de $250 \mathrm{kN}$, na temperatura ambiente.

Após a abertura da trinca os corpos de prova foram quebrados para avaliação da trinca e as medições, tanto da pré-trinca por fadiga como do crescimento lento da trinca, foram feitas em um projetor de perfil da marca Nikon com ampliação de 50 vezes e sistema de medição com resolução de $0,001 \mathrm{~mm}$. Os dados foram processados através de um programa para microcomputador no Laboratório de Propriedades Mecânicas da EESC. 


\section{5 - RESULTADOS}

\section{1 - Análises Químicas}

As análises químicas dos cordões de solda são apresentadas nas tabelas 5.1 e 5.2 .

TABELA 5.1 - Análise Química dos cordões de solda (\% peso)

\begin{tabular}{c|cccccccc}
\hline \multicolumn{1}{c}{} & $\mathbf{1 p}$ & $\mathbf{2 p}$ & $\mathbf{3 p}$ & $\mathbf{4 p}$ & $\mathbf{5 p}$ & $\mathbf{6 p}$ & $\mathbf{7 p}$ & $\mathbf{8 p}$ \\
\hline $\mathbf{C}$ & 0,08 & 0,07 & 0,11 & 0,08 & 0,07 & 0,10 & 0,08 & 0,07 \\
$\mathbf{S i}$ & 0,43 & 0,38 & 0,41 & 0,41 & 0,39 & 0,40 & 0,38 & 0,37 \\
$\mathbf{M n}$ & 1,37 & 1,27 & 1,55 & 1,41 & 1,42 & 1,54 & 1,41 & 1,30 \\
$\mathbf{P}$ & 0,04 & 0,04 & 0,04 & 0,04 & 0,03 & 0,03 & 0,03 & 0,04 \\
$\mathbf{S}$ & 0,08 & 0,01 & 0,01 & 0,01 & 0,01 & 0,01 & 0,01 & 0,01 \\
$\mathbf{C r}$ & 0,58 & 0,57 & 0,18 & 0,18 & 0,15 & 0,17 & 0,54 & 0,54 \\
$\mathbf{N i}$ & 0,11 & 0,12 & 0,09 & 0,09 & 0,08 & 0,09 & 0,11 & 0,11 \\
$\mathbf{M o}$ & 0,16 & 0,16 & 0,02 & 0,02 & 0,02 & 0,02 & 0,15 & 0,16 \\
$\mathbf{C u}$ & 0,22 & 0,23 & 0,21 & 0,21 & 0,19 & 0,19 & 0,20 & 0,21 \\
$\mathbf{A l}$ & 0,01 & 0,02 & 0,01 & 0,02 & 0,02 & 0,01 & 0,01 & 0,02 \\
\hline
\end{tabular}

TABELA 5.2 - Análise de Oxigênio e Nitrogênio (ppm em peso)

\begin{tabular}{c|cccccccc}
\hline \multicolumn{1}{r}{} & $\mathbf{1 p}$ & $\mathbf{2 p}$ & $\mathbf{3 p}$ & $\mathbf{4 p}$ & $\mathbf{5 p}$ & $\mathbf{6 p}$ & $\mathbf{7 p}$ & $\mathbf{8 p}$ \\
\hline $\mathbf{0}$ & 464 & 721 & 393 & 629 & 592 & 352 & 538 & 857 \\
$\mathbf{N}$ & 74 & 76 & 50 & 48 & 48 & 48 & 77 & 78
\end{tabular}

OBS: Para alguns ensaios e análises não se faz necessário que se obtenha dados dos 16 cordões, haja visto que o tratamento pós soldagem não influencia em alguns resultados. (como por ex. nas análises químicas e na diluição da chapa base) 


\section{2 - Diluicão da Chapa Base}

A tabela 5.3 mostra os resultados dos cálculos para a diluição da chapa base para as oito condições dadas.

\begin{tabular}{|c|c|}
\hline & Diluição (\%) \\
\hline $1 p$ & 36 \\
\hline $2 p$ & 37 \\
\hline $3 p$ & 34 \\
\hline $4 p$ & 37 \\
\hline $5 p$ & 35 \\
\hline $6 p$ & 37 \\
\hline $7 p$ & 34 \\
\hline $8 p$ & 35 \\
\hline
\end{tabular}

\section{3 - Exames Metalográficos}

Através dos exames metalográficos de MACROGRAFIA pode-se calcular a diluição da chapa base, assim como visualizar a qualidade das soldas quanto a reforço e penetração.

Através dos exames metalográficos de MICROGRAFIA fez-se a quantificação das fases presentes nos cordões de solda, assim como a quantificação das microfases.

Acompanhando essas micrografias tem-se as tabelas 5.4 e $5.5 \mathrm{com}$ os resultados das quantificações de fases e microfases. 


\subsection{1 - Macrografias}
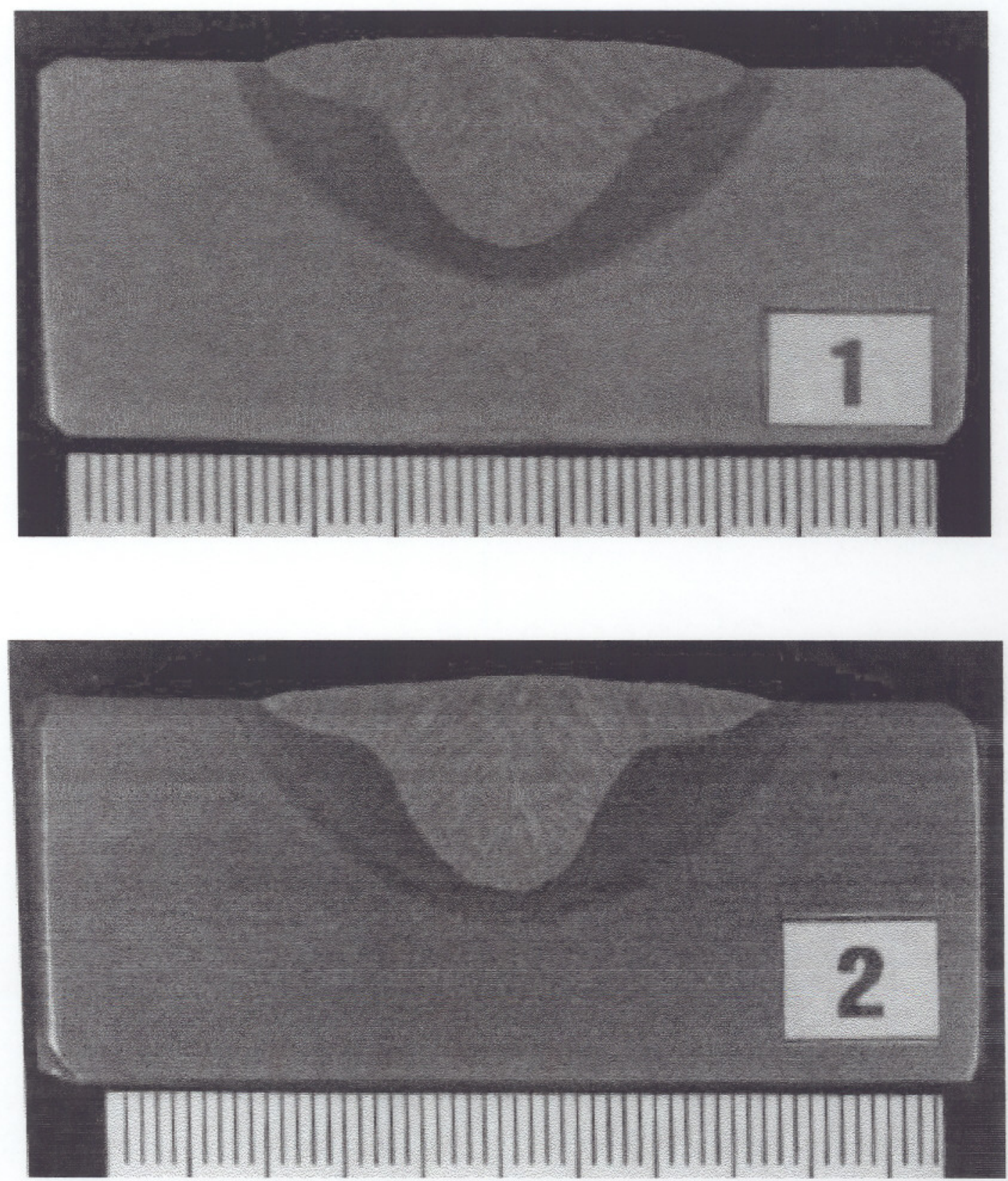

Figura 5.1 - Macrografias das amostras $1 p$ e $2 p .($ escala em mm) 

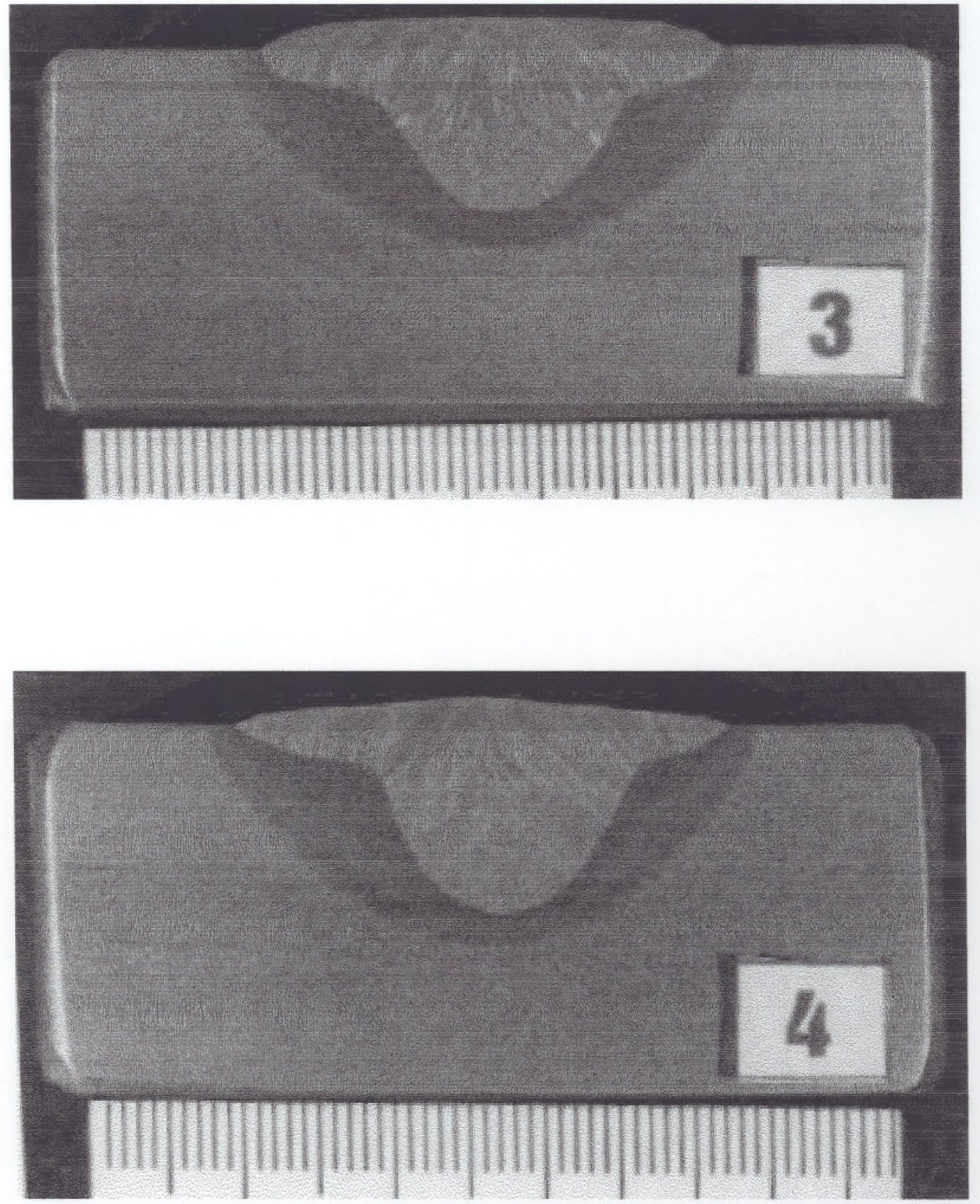

Figura 5.2 - Macrografias das amostras $3 p$ e $4 p .($ escala em mm) 

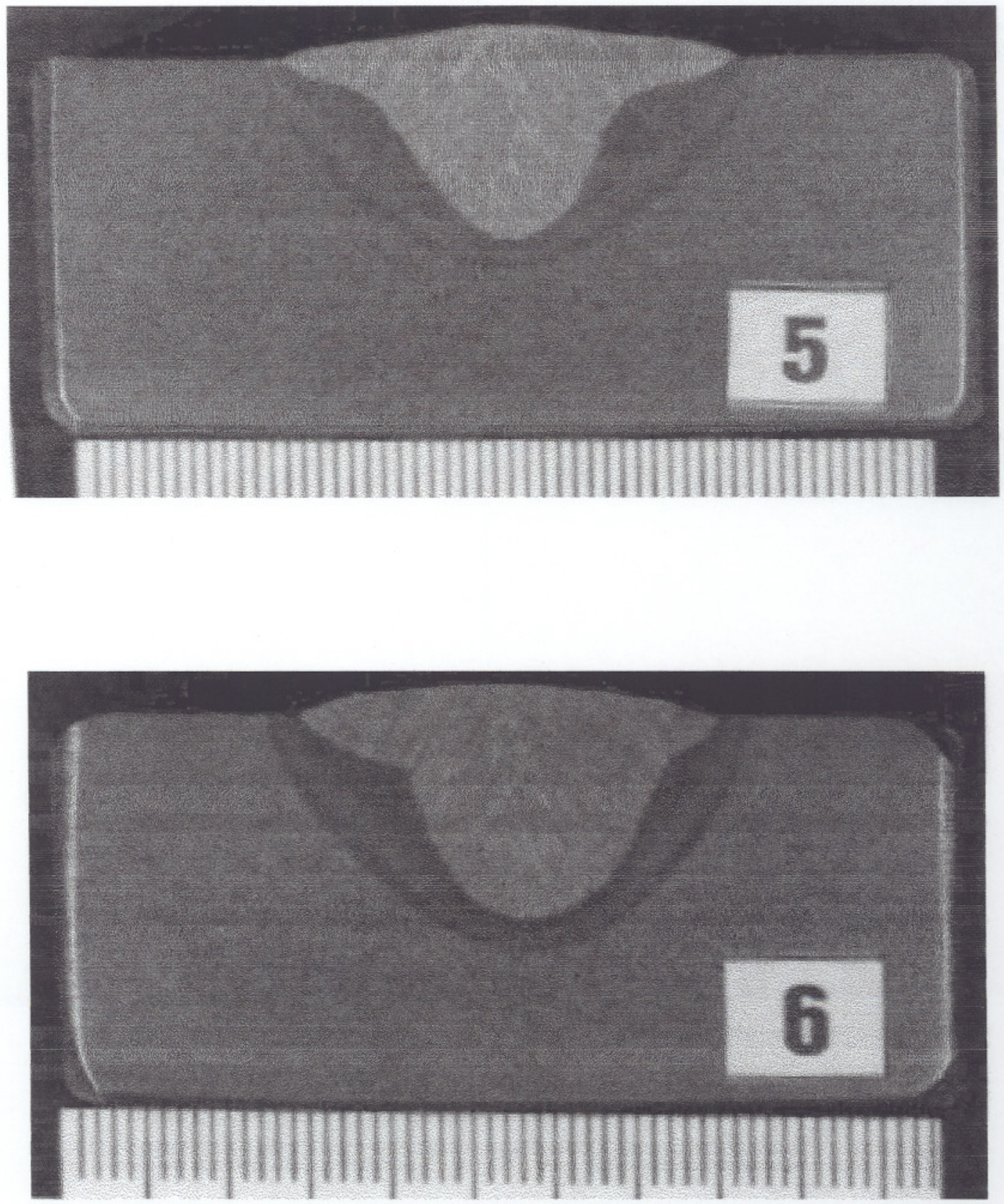

Figura 5.3 - Macrografias das amostras $5 p$ e $6 p .($ escala em mm) 

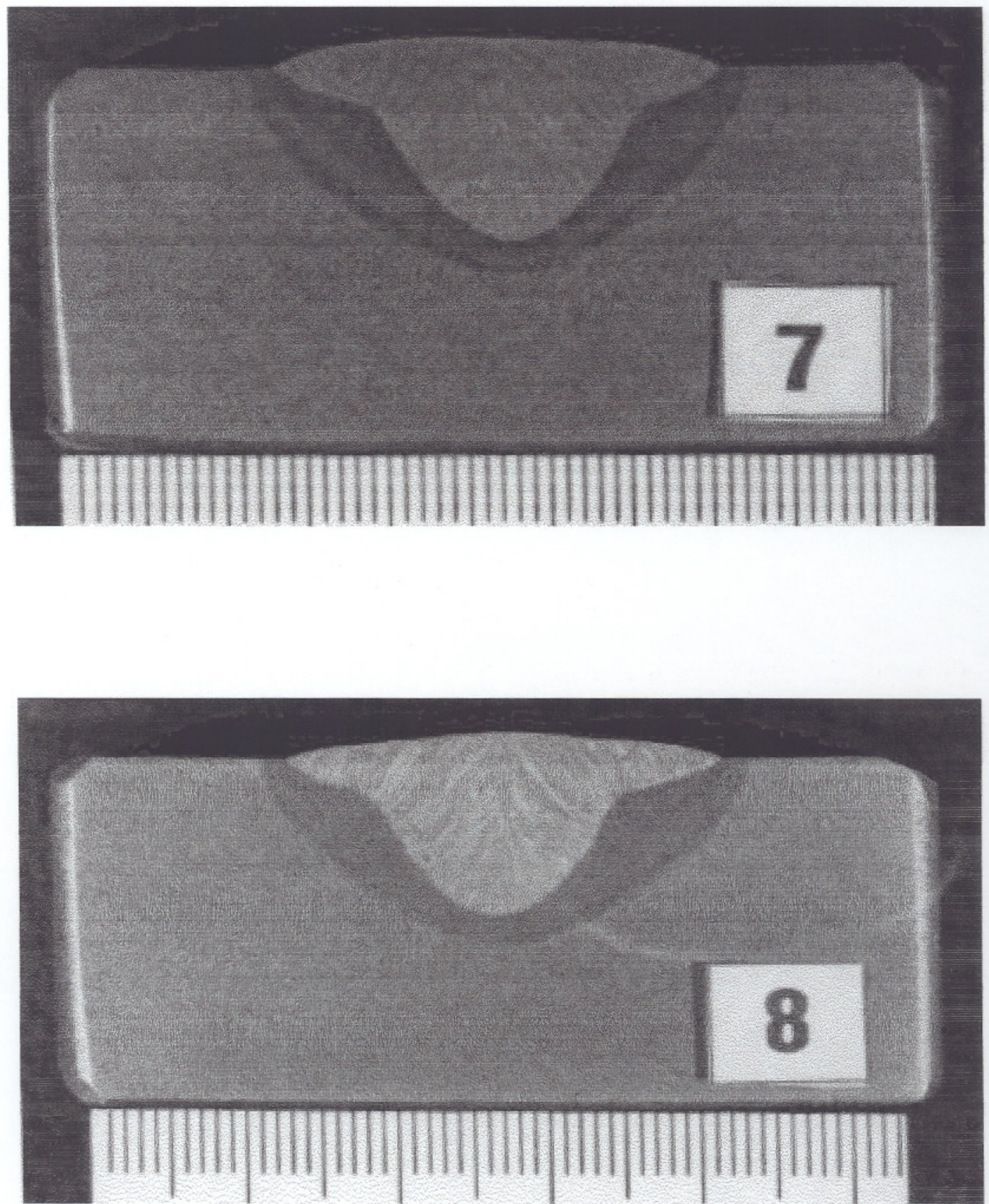

Figura 5.4 - Macrografias das amostras $7 p$ e $8 p .($ escala em mm) 


\subsection{2 - Micrografias}

Foram realizados dois tipos de micrografias: o primeiro tipo, em preto e branco para quantificação de fases e o colorido para quantificação das microfases. Os resultados das quantificações são mostrados nas tabelas $5.4 \mathrm{e}$ 5.5 .

TABELA 5.4 - Quantificação de fases (\%)

$\begin{array}{ccccccccc} & \mathbf{1 p} & \mathbf{2 p} & \mathbf{3 p} & \mathbf{4 p} & \mathbf{5 p} & \mathbf{6 p} & \mathbf{7 p} & \mathbf{8 p} \\ \mathbf{A F} & 72 & 75 & 51 & 43 & 62 & 50 & 63 & 64 \\ \mathbf{P F ( G )} & 24 & 16 & 36 & 46 & 30 & 42 & 24 & 27 \\ \mathbf{F S ( N A )} & 3 & 6 & 6 & 6 & 6 & 4 & 10 & 7 \\ \mathbf{F S ( A )} & 0,3 & 0,3 & 3 & 1 & 0,2 & 3 & 1 & - \\ \mathbf{P F} & 0,5 & 3 & 2 & 1 & 1,2 & 0,3 & 2 & 2 \\ \mathbf{F C} & - & 0,2 & 2 & 2 & 0,5 & 1 & 0,1 & - \\ \mathbf{P F ( I )} & 0,2 & 0,1 & 1 & 0,1 & 0,6 & - & 0,1 & -\end{array}$

TABELA 5.5 - Quantificação de Microfase

\begin{tabular}{c|c|c|c}
\hline & \% Microfase & \multicolumn{2}{c}{ \% Microfase } \\
\hline $\mathbf{1 p 3}$ & 3,1 & $\mathbf{1 p 2}$ & 0,3 \\
$\mathbf{2 p 3}$ & 5,0 & $\mathbf{2 p 2}$ & 0,5 \\
$\mathbf{3 p 3}$ & 3,0 & $\mathbf{3 p 2}$ & 1,0 \\
$\mathbf{4 p 3}$ & 2,5 & $\mathbf{4 p 2}$ & 0,7 \\
$\mathbf{5 p 1}$ & 4,1 & $\mathbf{5 p 2}$ & 0 \\
$\mathbf{6 p 1}$ & 6,1 & $\mathbf{6 p 2}$ & 1,2 \\
$\mathbf{7 p 1}$ & 10,0 & $\mathbf{7 p 2}$ & 0 \\
$\mathbf{8 p 1}$ & 5,0 & $\mathbf{8 p 2}$ & 0,6 \\
\hline
\end{tabular}


As figuras 5.5 e 5.6 mostram as micrografias em preto e branco, com ampliação de 500 vezes.

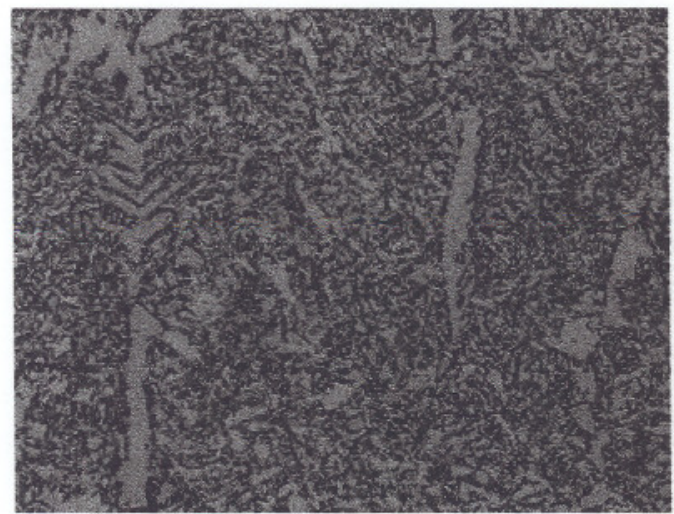

(a) $1 p-72 \%$ AF

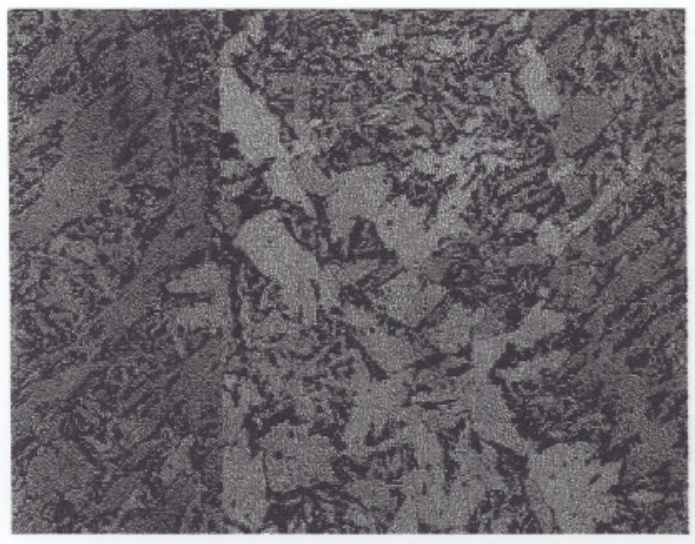

(c) $3 p-51 \%$ AF

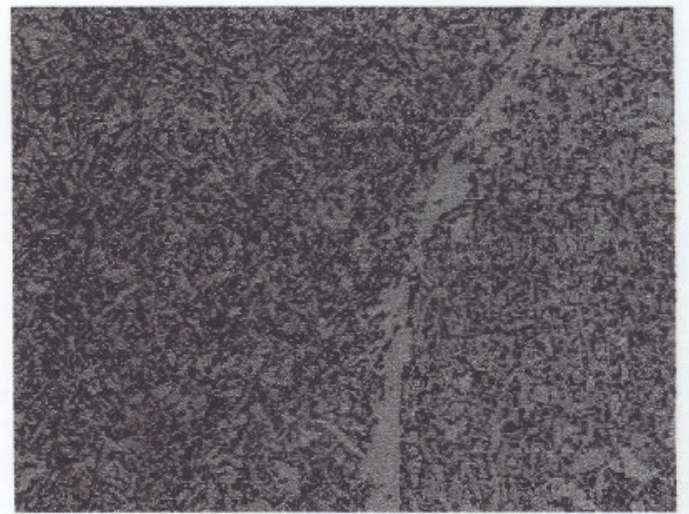

(b) $2 p-75 \%$ AF

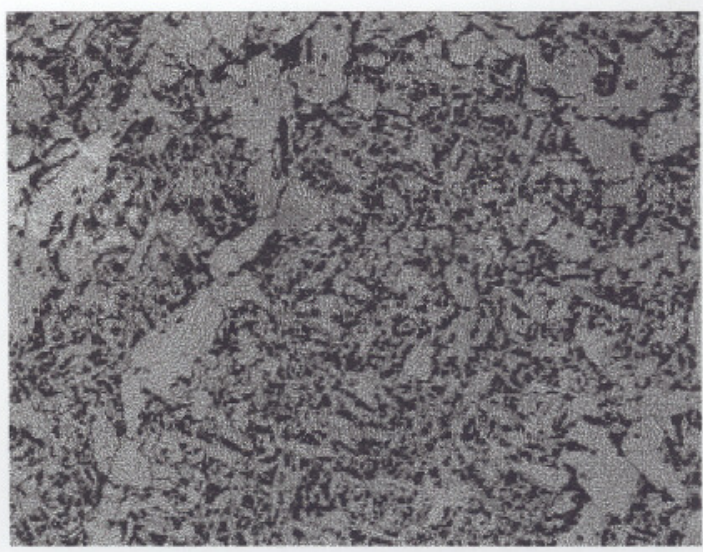

(d) $4 p-43 \%$ AF

Figura $5.5-$ (a) amostra $1 p$; (b) amostra $2 p$

(c) amostra 3p ; (d) amostra $4 p$ 


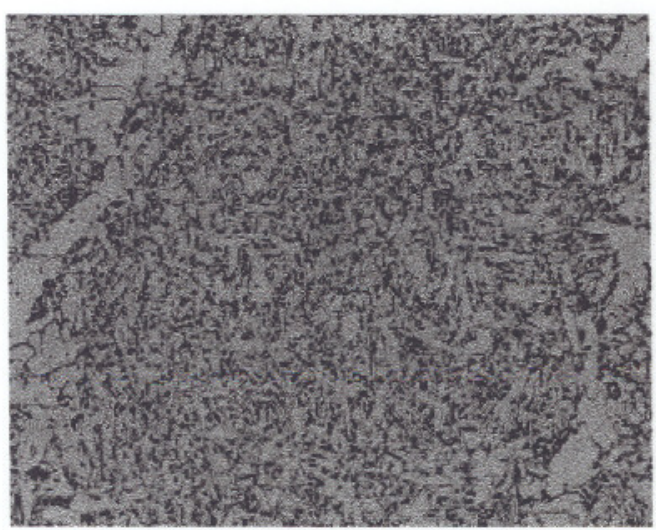

(a) $5 p-62 \%$ AF

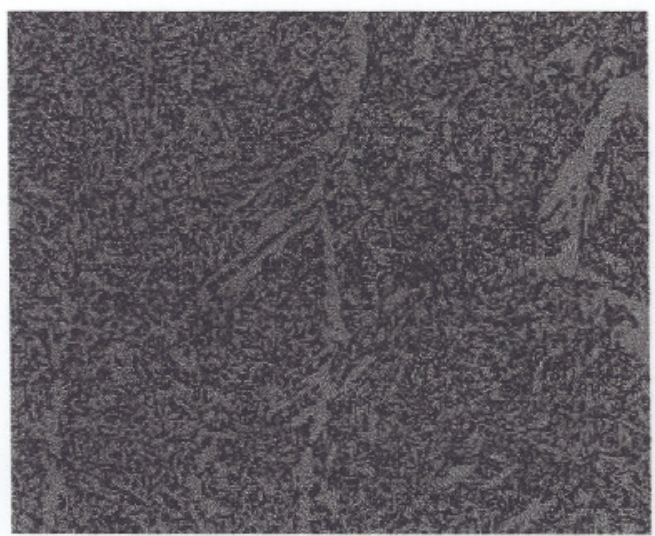

(c) $7 p-63 \%$ AF

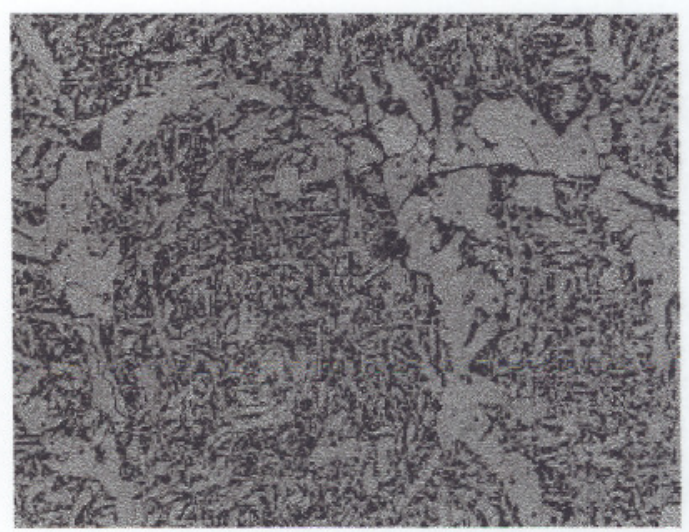

(b) $6 p-50 \%$ AF

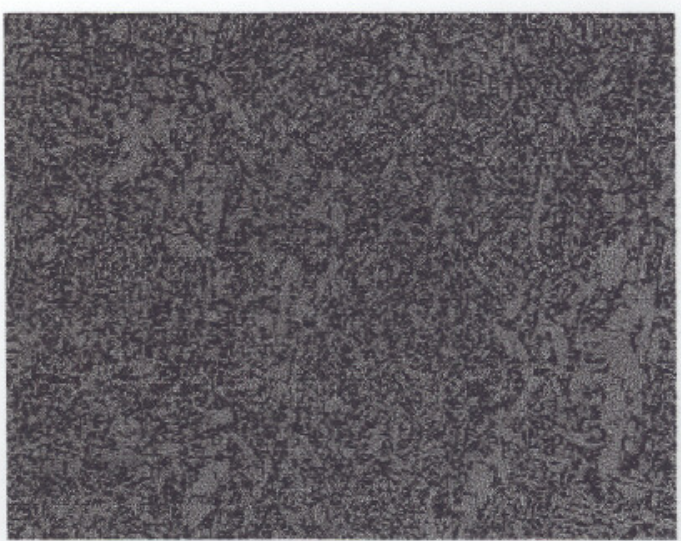

(d) $8 p-64 \%$ AF

Figura 5.6 - (a) amostra 5p ; (b) amostra 6p

(c) amostra $7 p$; (d) amostra $8 p$ 
As figuras de 5.7 a 5.14 mostram as micrografias coloridas, com aumento de 1800 vezes. As setas brancas identificam a austenita retida.

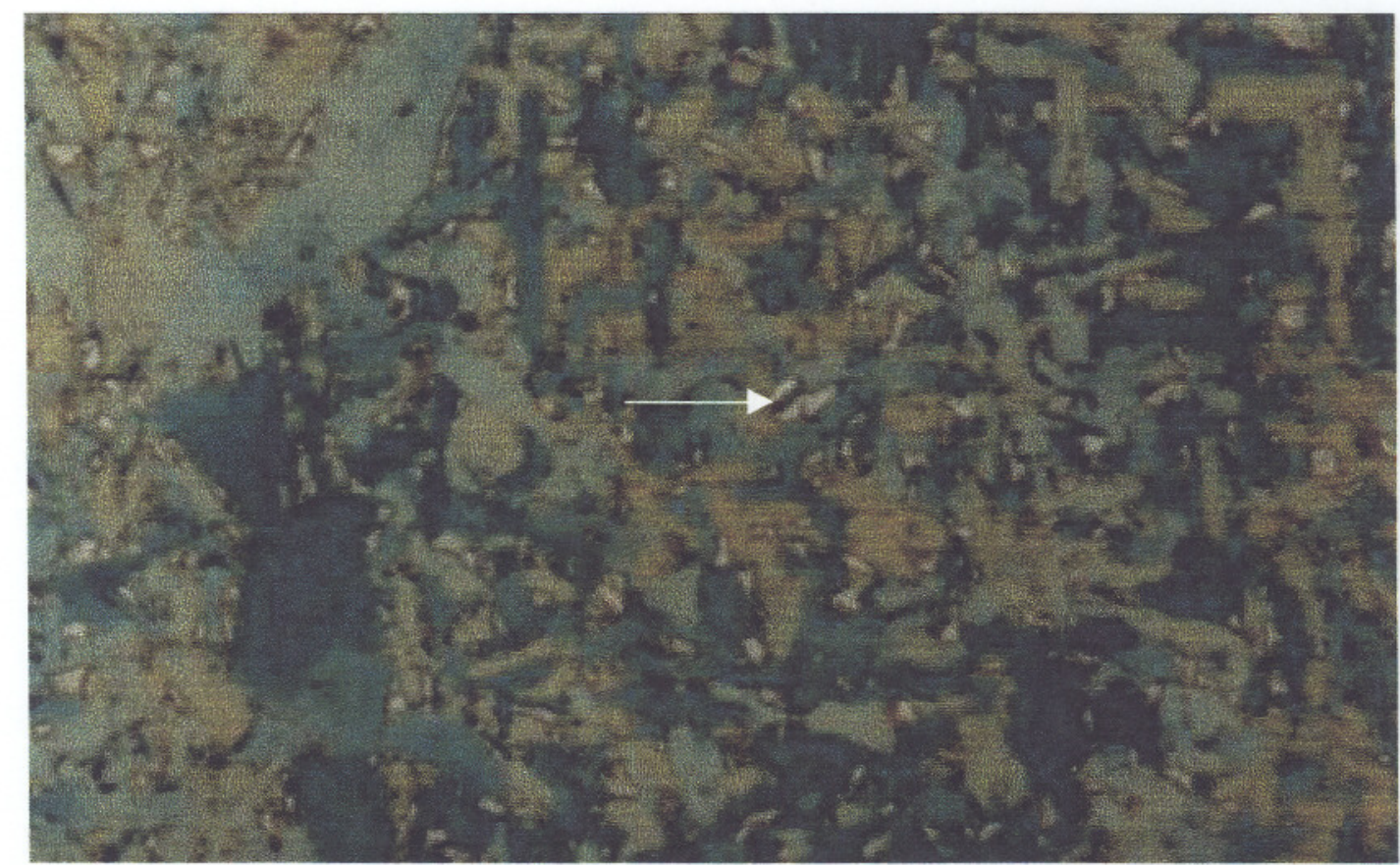

a) amostra $1 \mathrm{p} 3$, teor de Austenita retida $-3,1 \%$

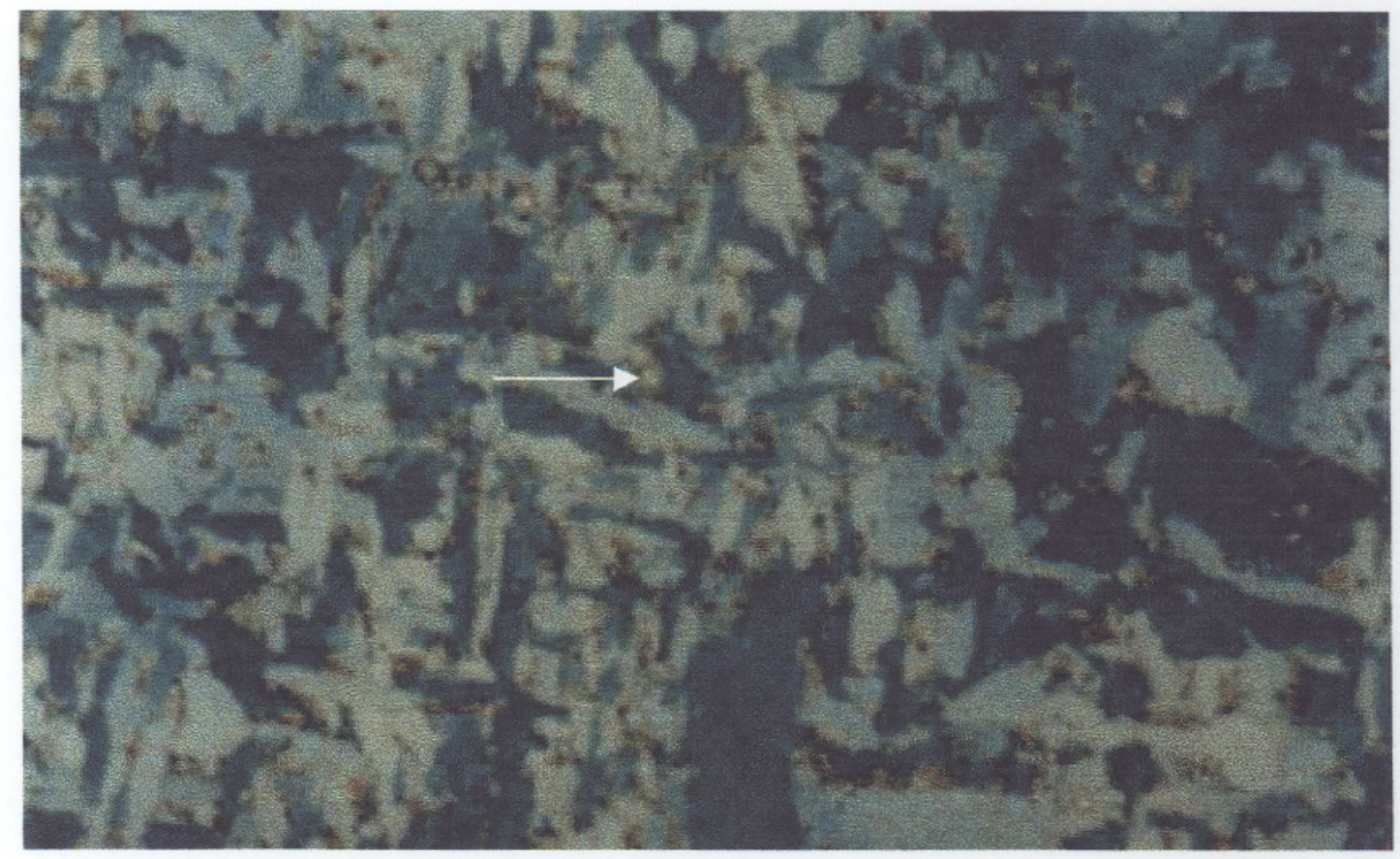

b) Amostra $1 \mathrm{p} 2$, teor de Austenita retida - 0,3\%

Figura 5.15 - Amostras 1p3 (a) e 1p2 (b) 


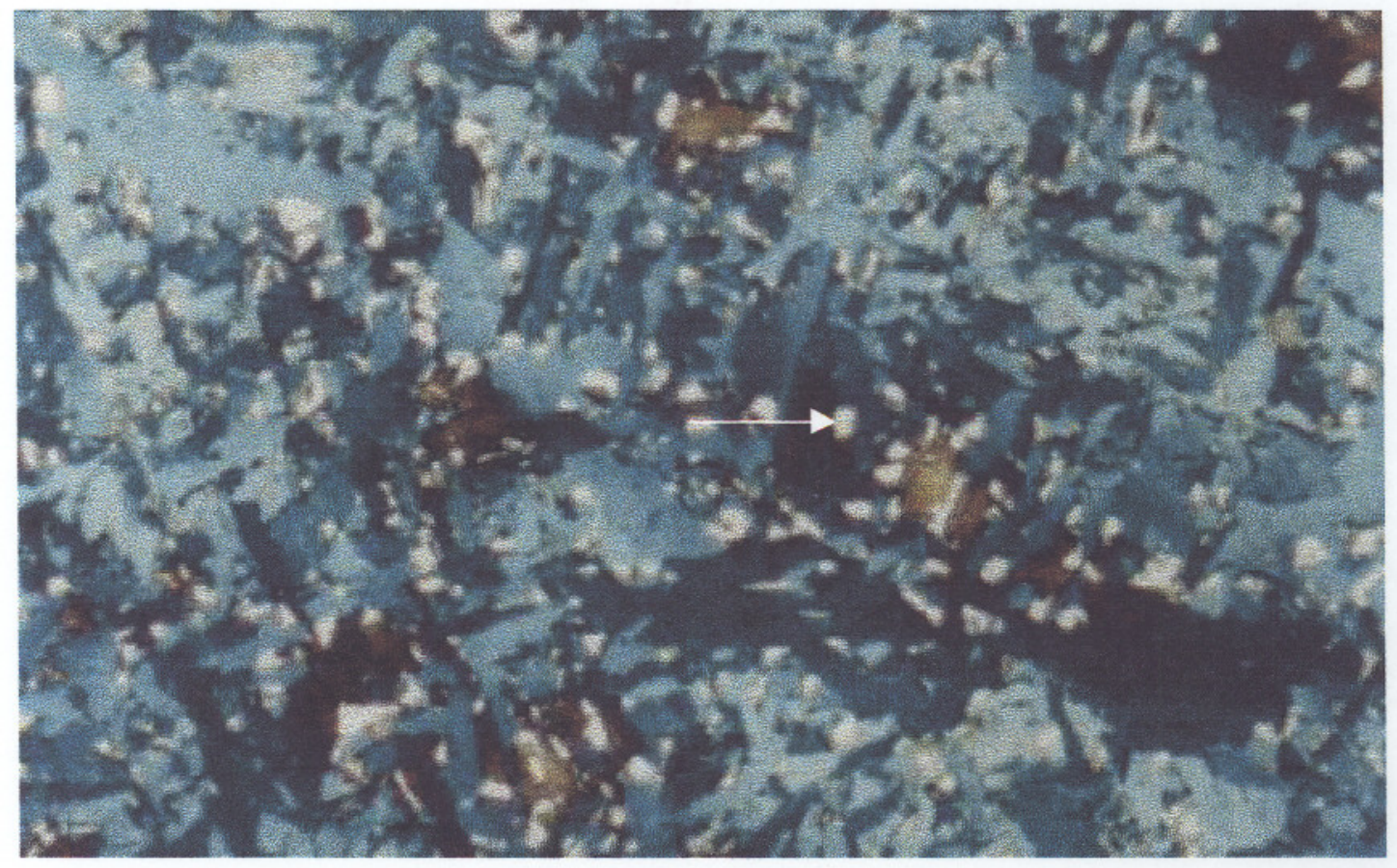

a) amostra $2 p 3$, teor de Austenita retida $-5,0 \%$

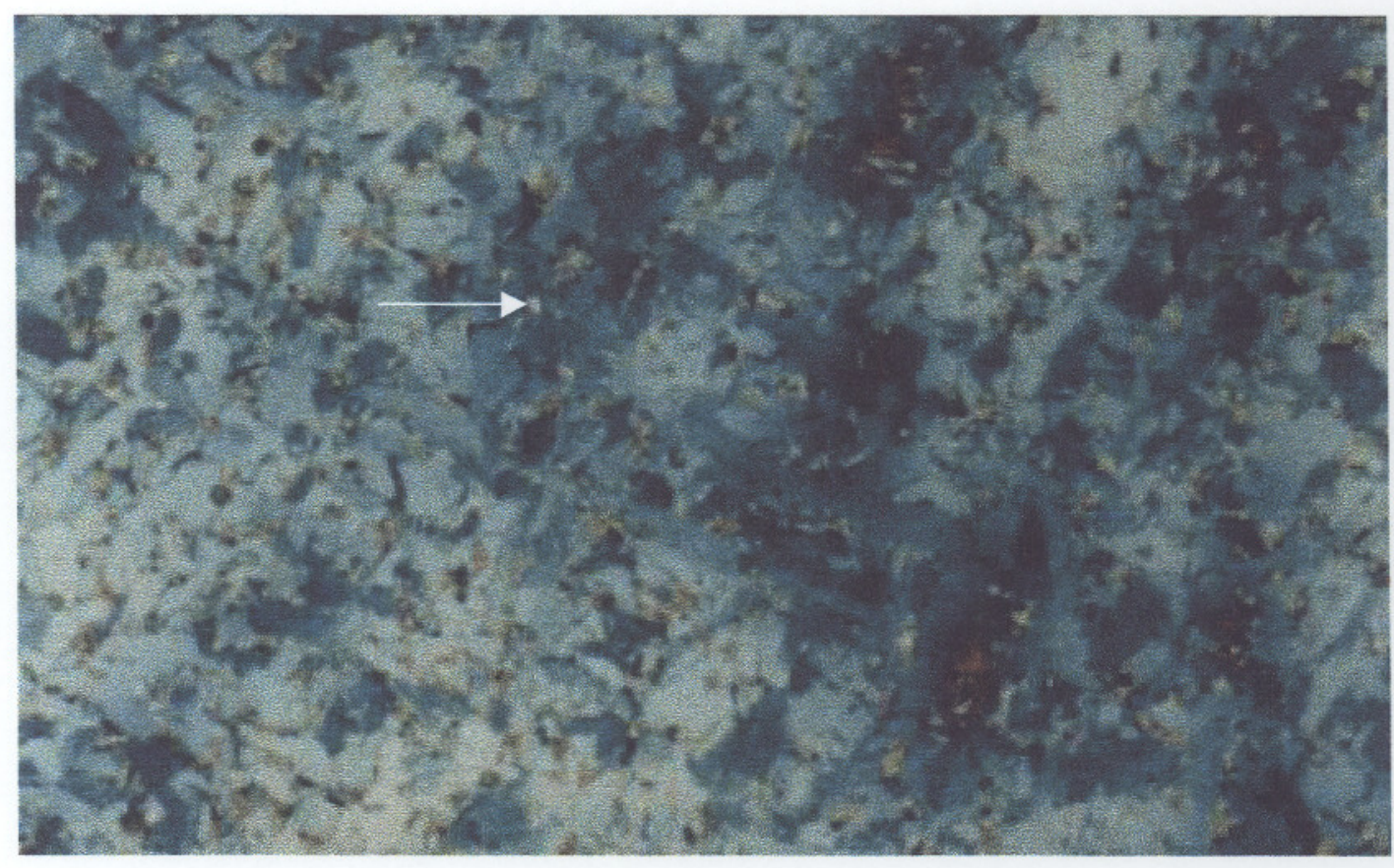

b) amostra $2 \mathrm{p} 2$, teor de Austenita retida - 0,5\%

Figura 5.16 - Amostras 2p3 (a) e 2p2 (b) 


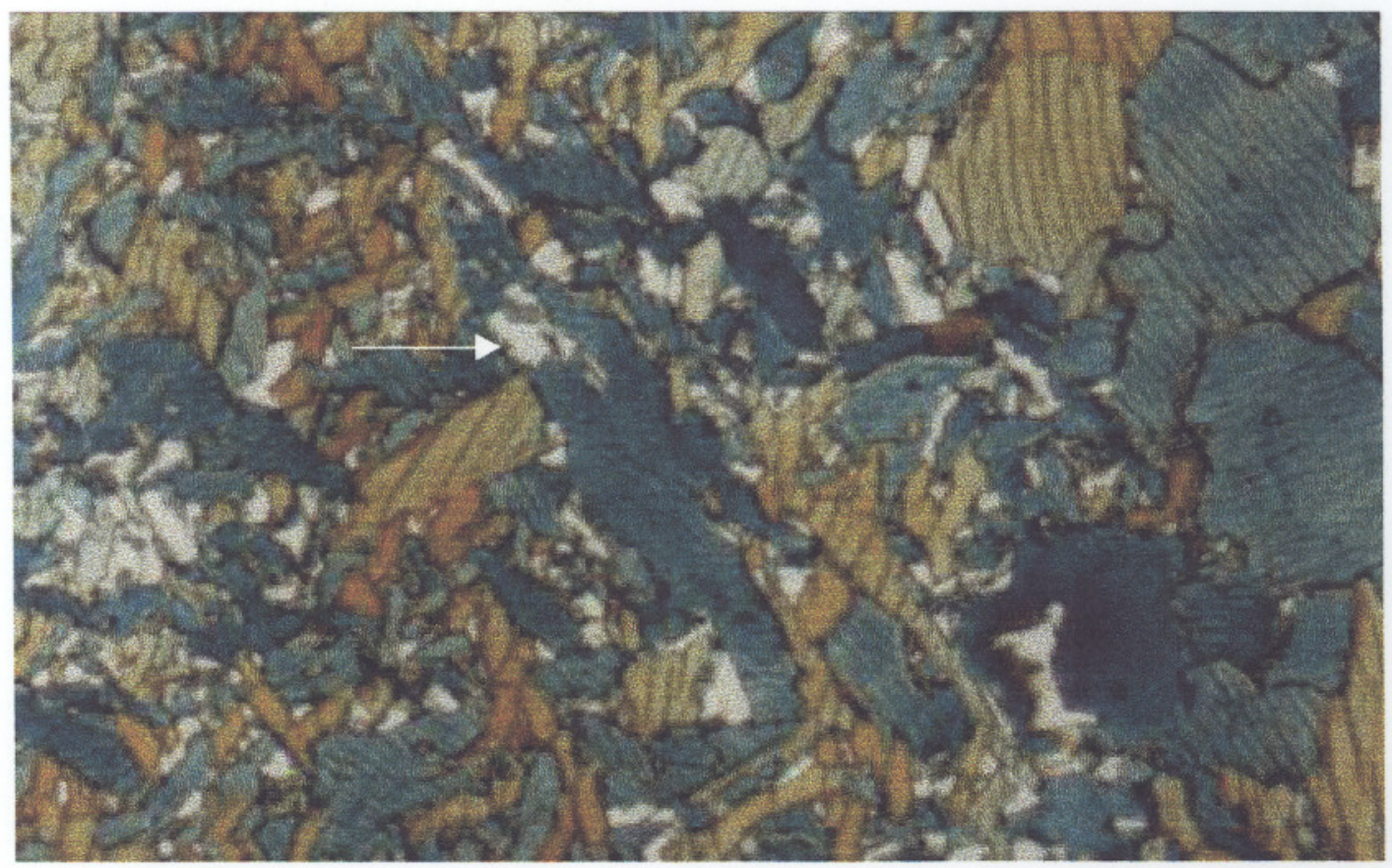

a) amostra $3 p 3$, teor de Austenita retida - 3,0\%

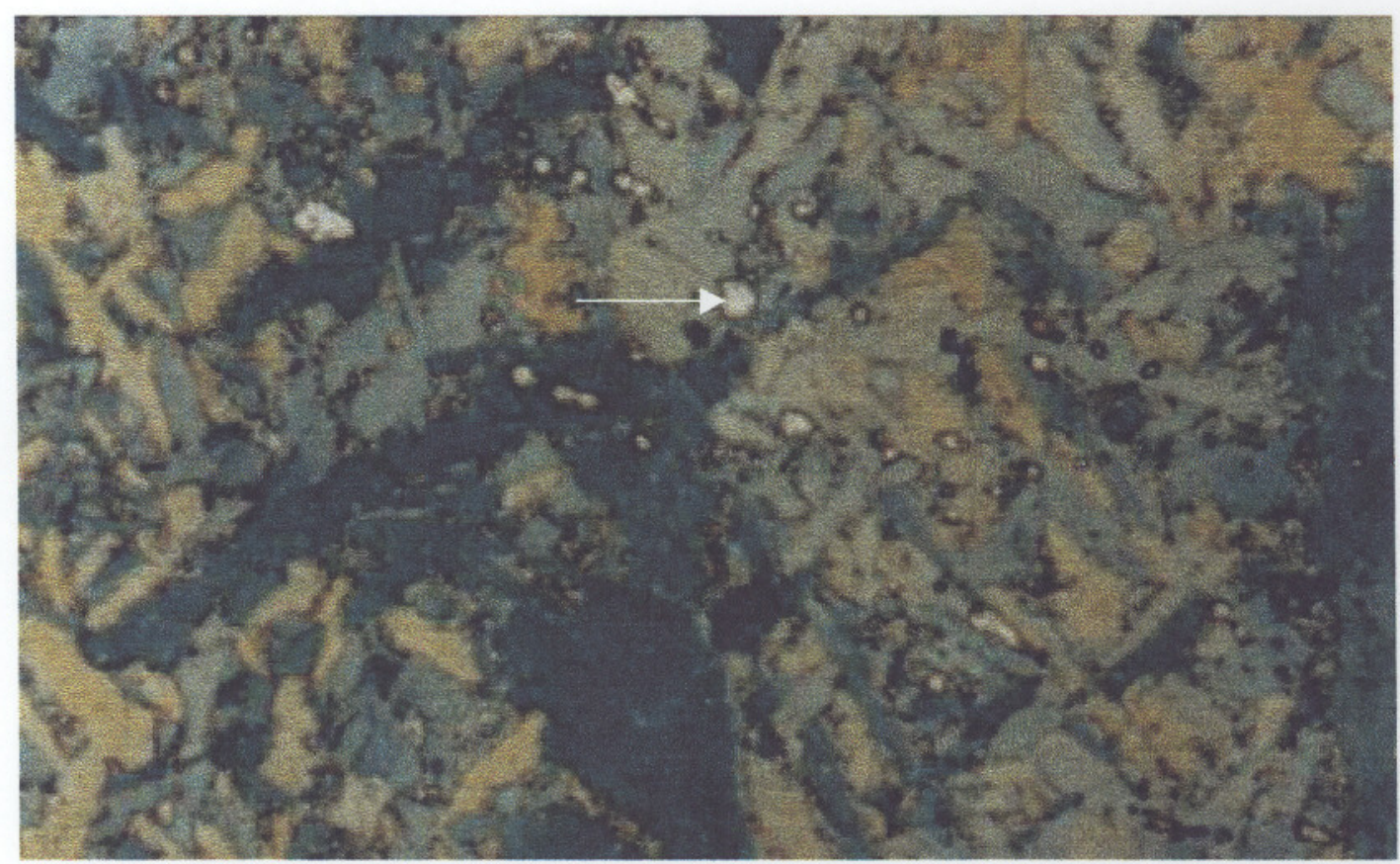

b) amostra $3 p 2$, teor de Austenita retida $-1,0 \%$

Figura 5.17 - Amostras 3p3 (a) e 3p2 (b) 


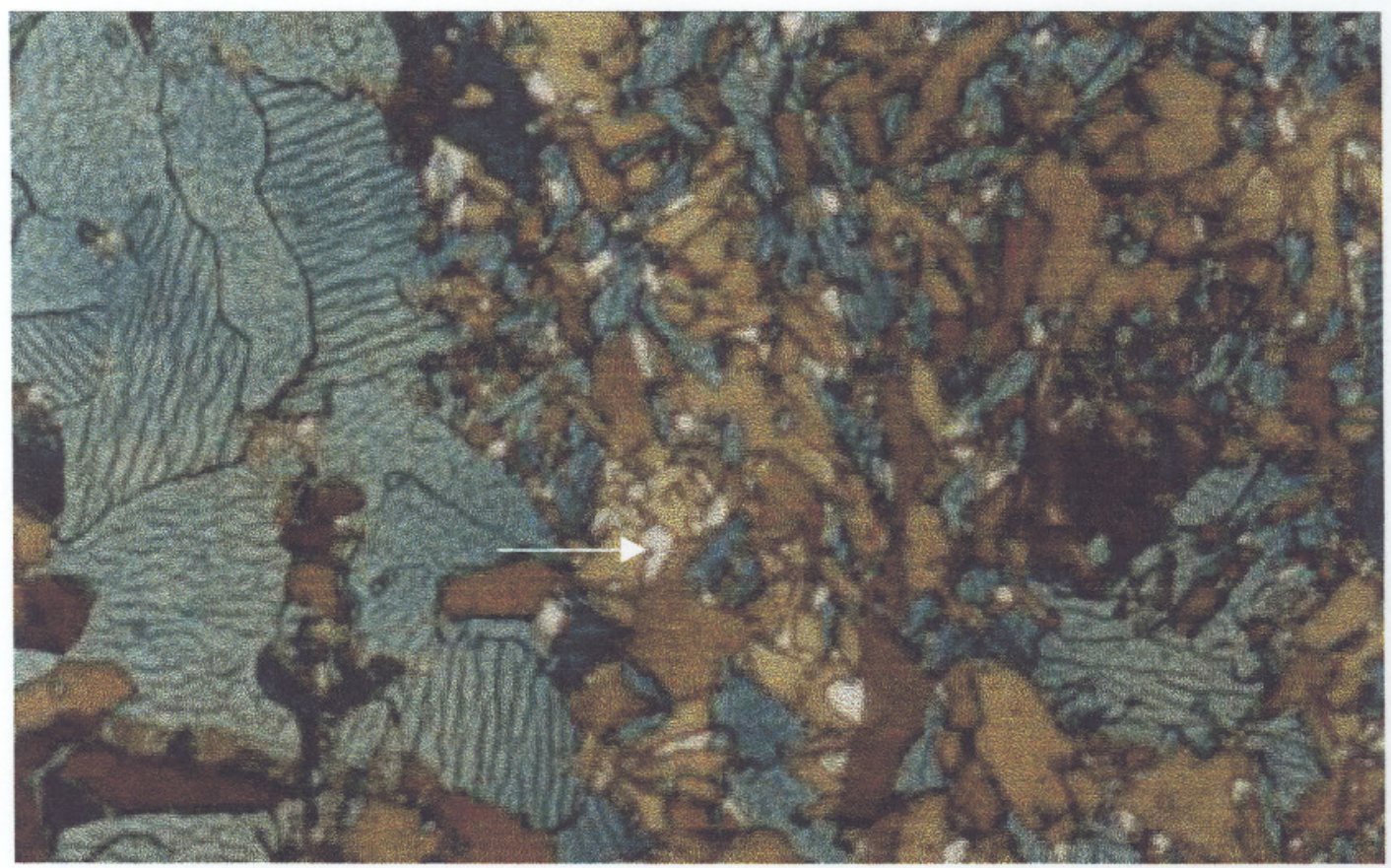

a) amostra $4 p 3$, teor de Austenita retida $-2,5 \%$

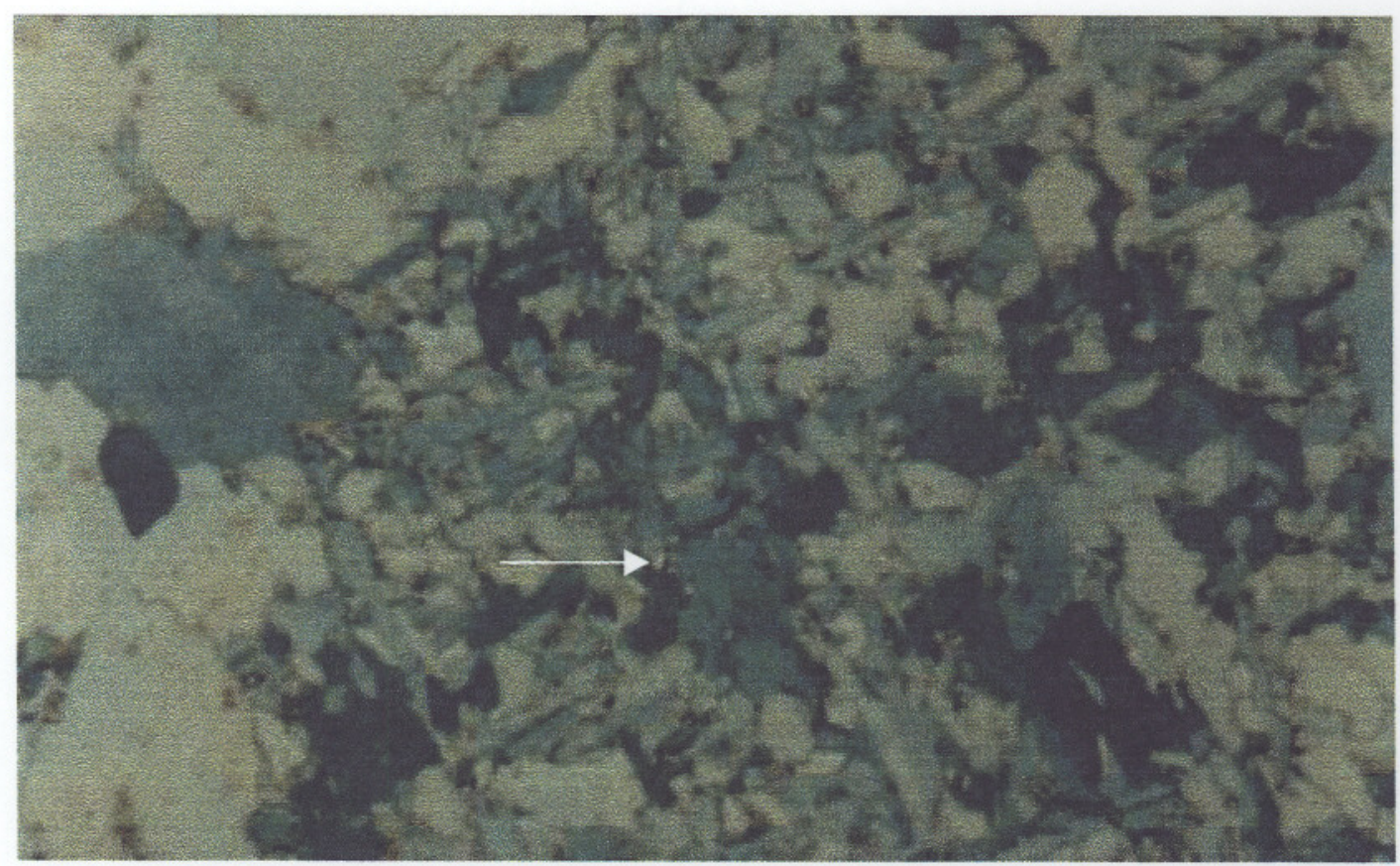

b) amostra $4 p 2$, teor de Austenita retida - 0,7\%

Figura 5.18 - Amostras 4p3 (a) e 4p2 (b) 


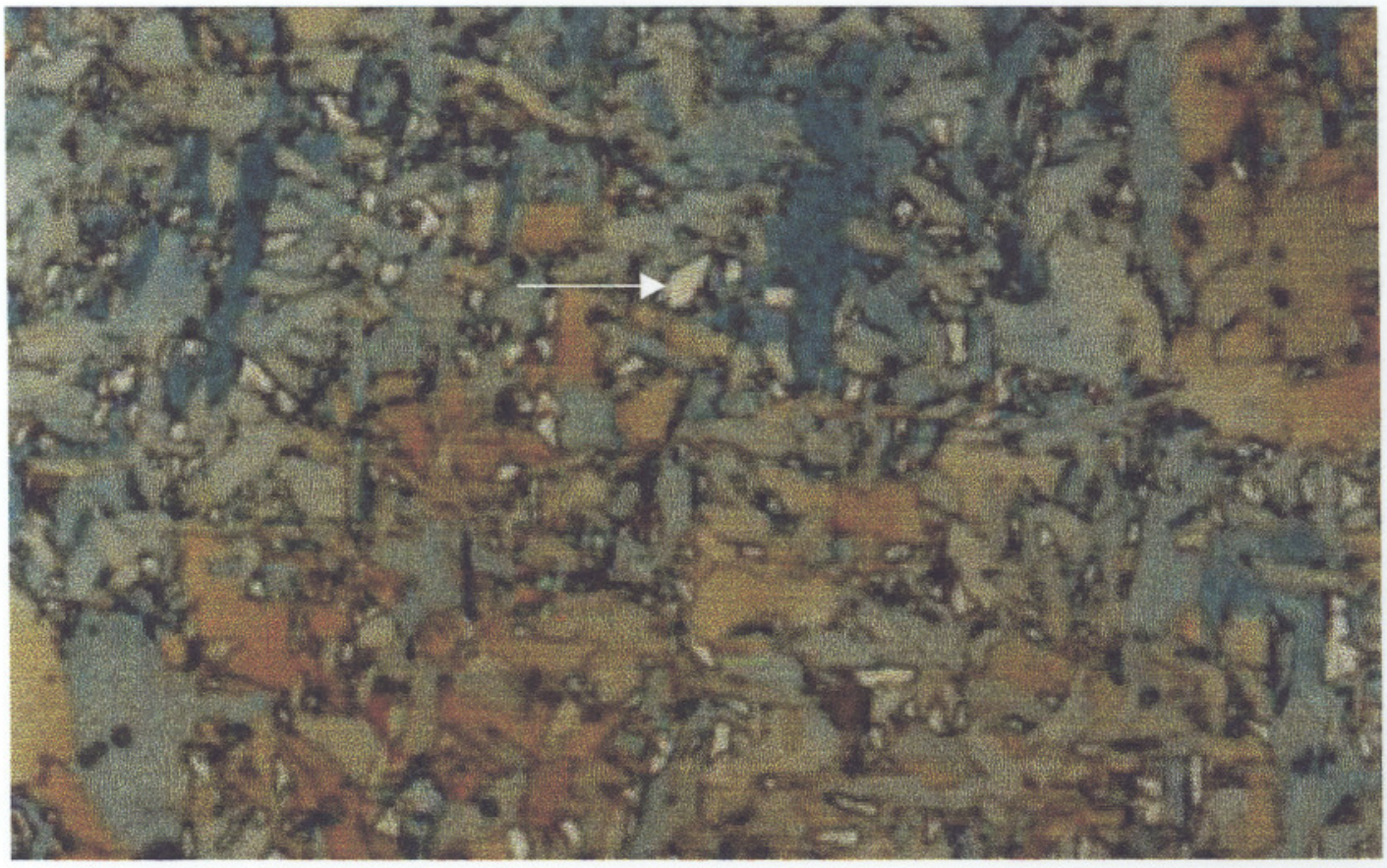

a) amostra $5 \mathrm{p} 1$, teor de Austenita retida - 4,1\%

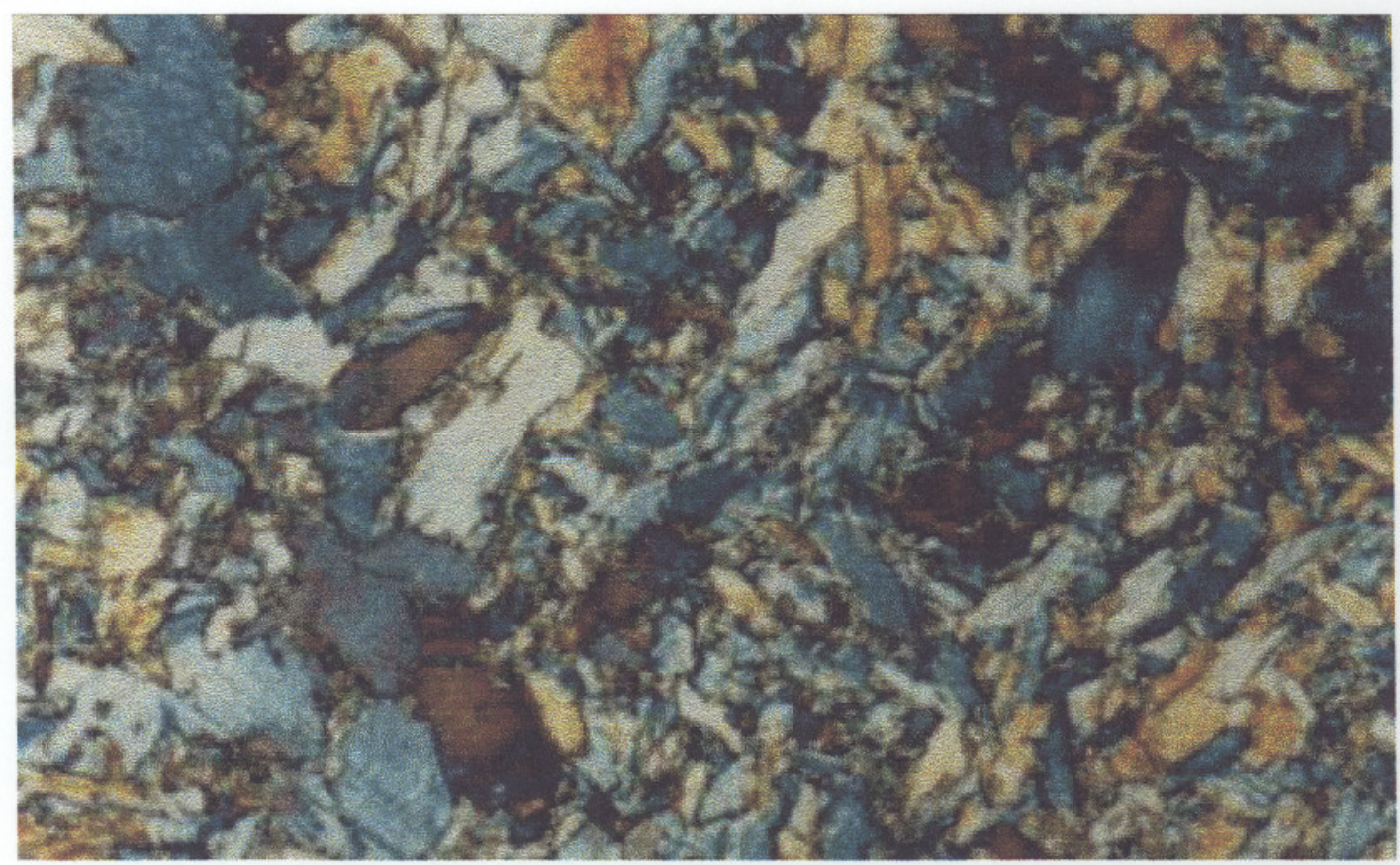

b) amostra $5 p 2$, teor de Austenita retida - 0\%

Figura 5.19 - Amostras 5p1(a) e 5p2 (b) 


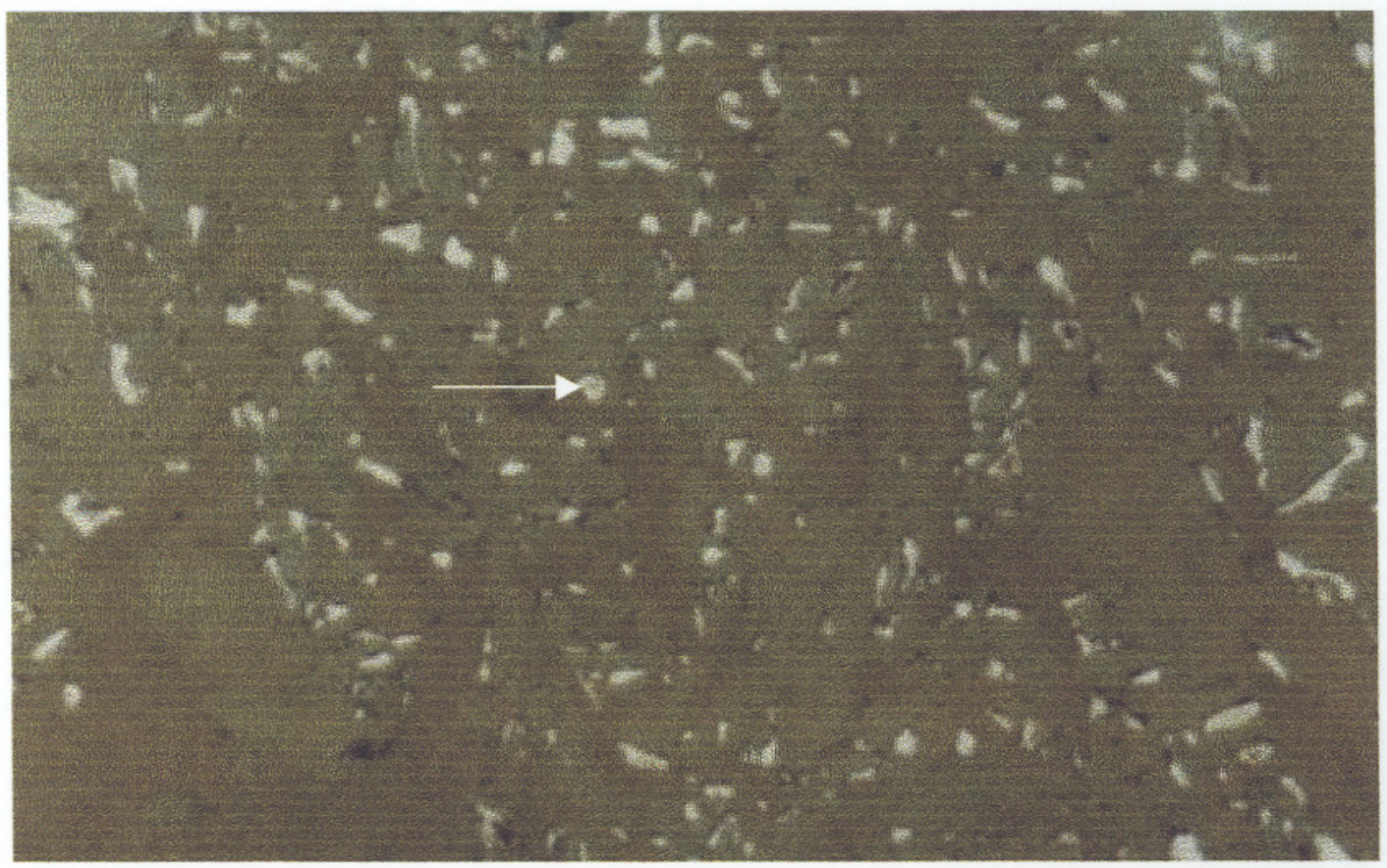

a) amostra $6 \mathrm{p} 1$, teor de Austenita retida $-6,1 \%$

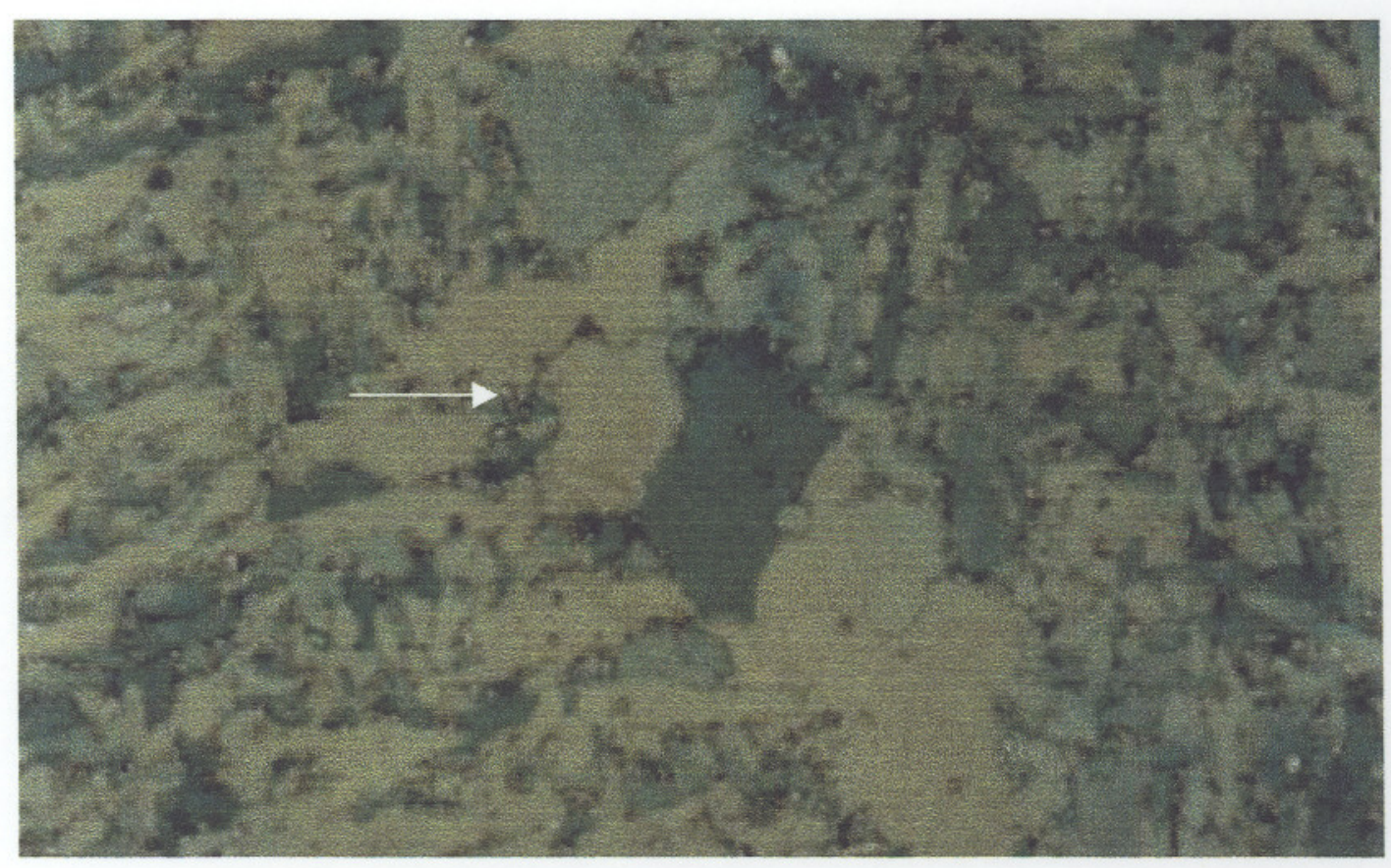

b) amostra $6 \mathrm{p} 2$, teor de Austenita retida $-1,2 \%$

Figura 5.20 - Amostras 6p1(a) e 6p2 (b) 


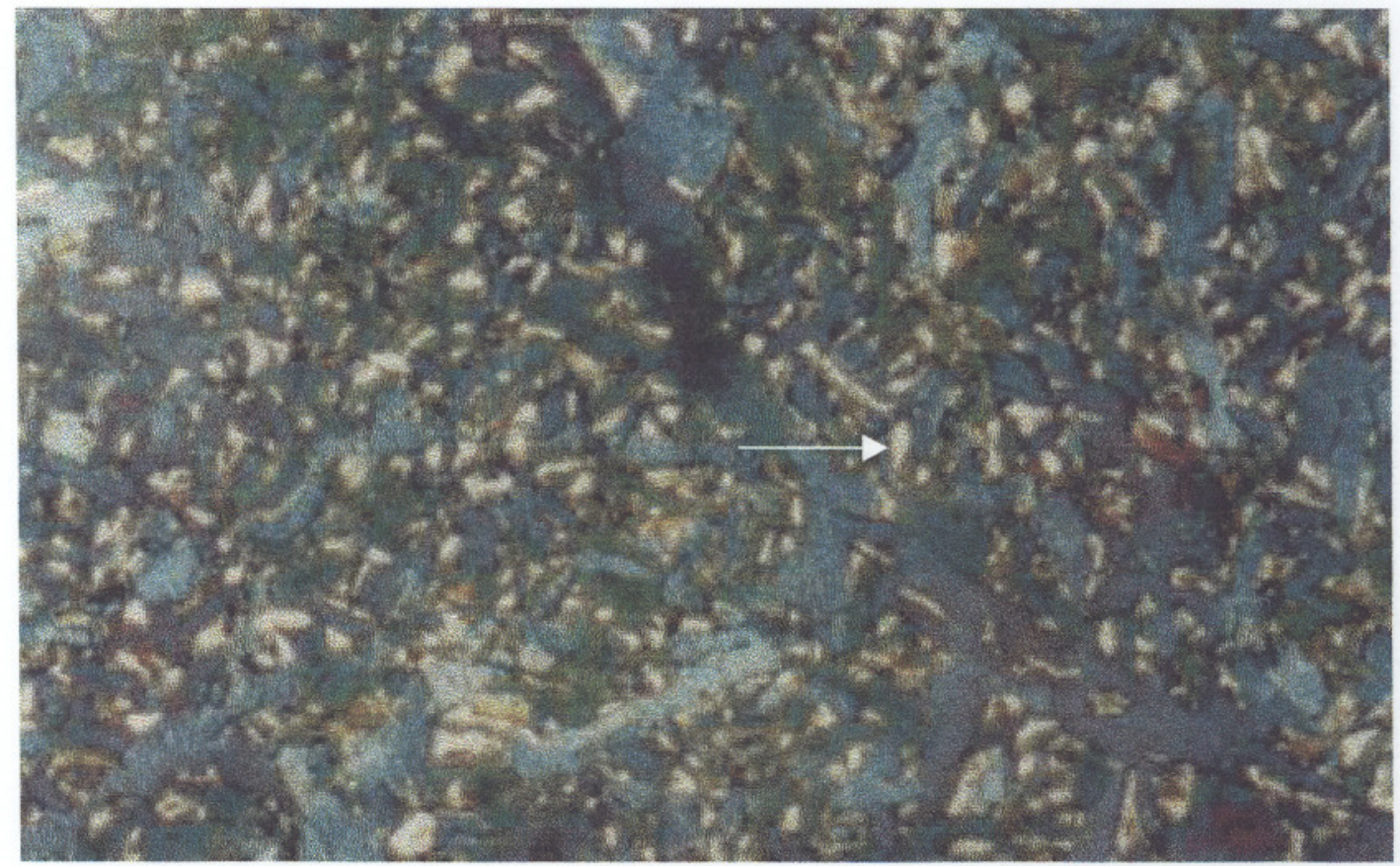

a) amostra $7 \mathrm{p} 1$, teor de Austenita retida $-10,0 \%$

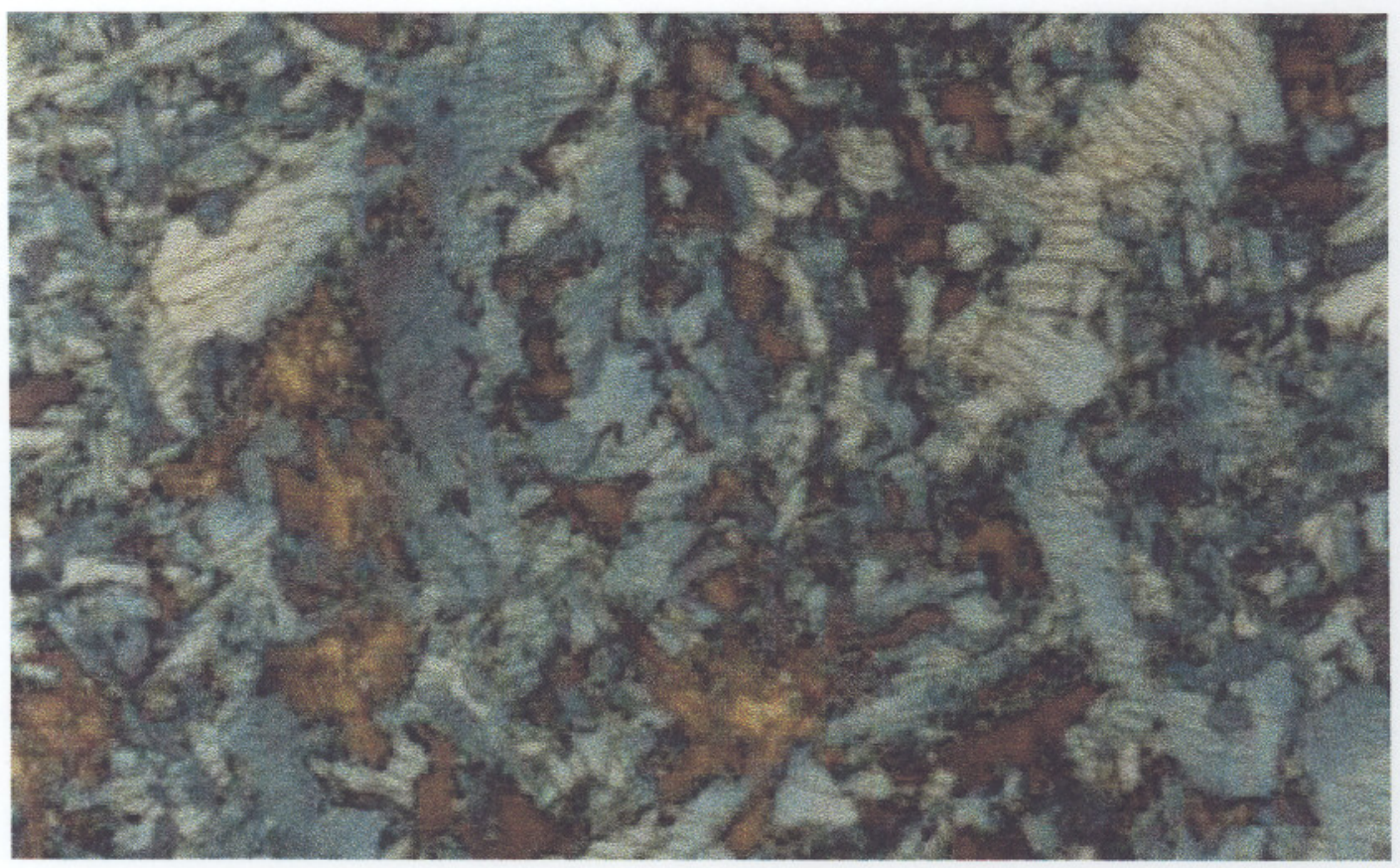

b) amostra $7 \mathrm{p} 2$, teor de Austenita retida - 0\%

Figura 5.21 - Amostras 7p1(a) e 7p2 (b) 


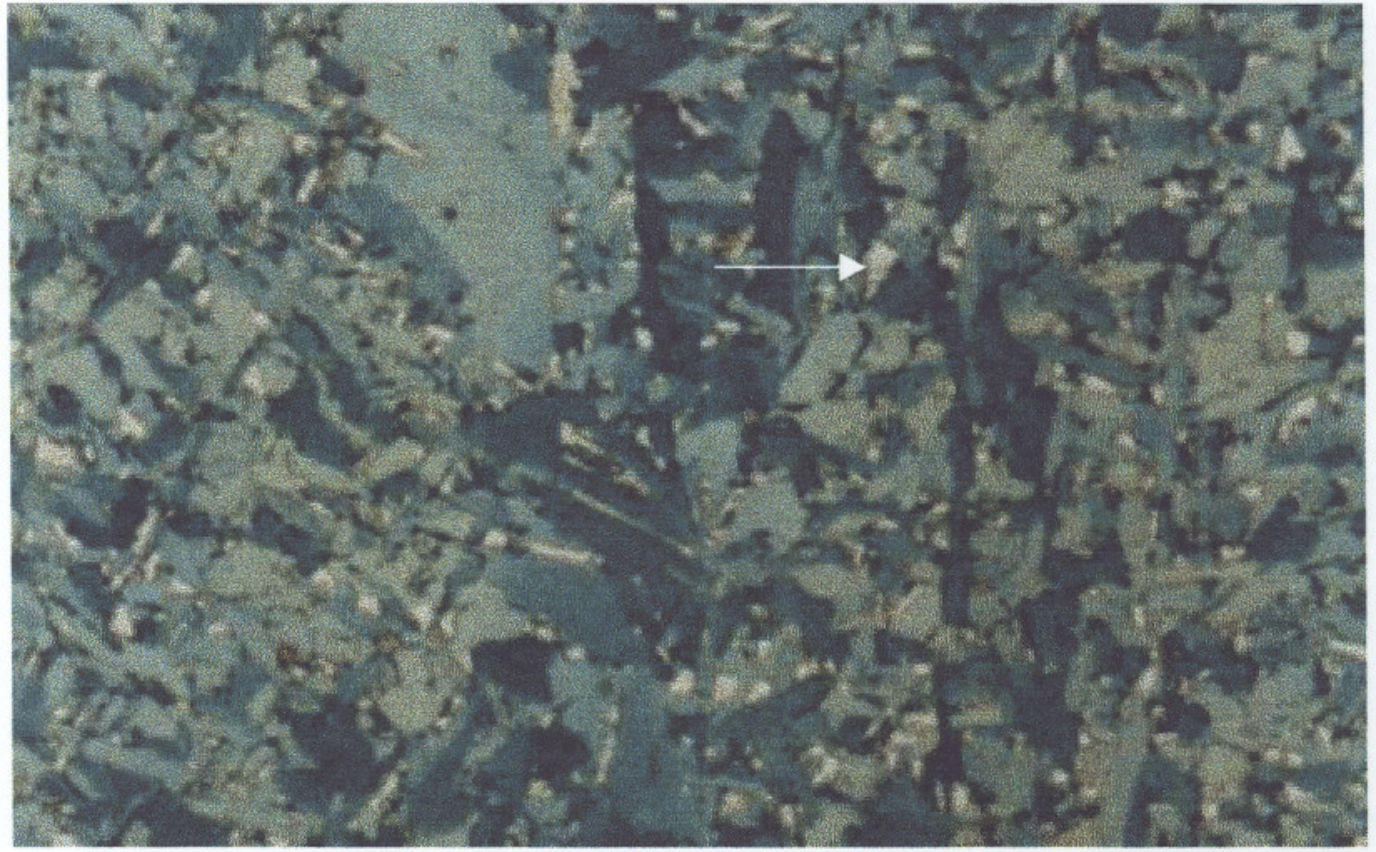

a) amostra $8 p 1$, teor de Austenita retida - 5,0\%

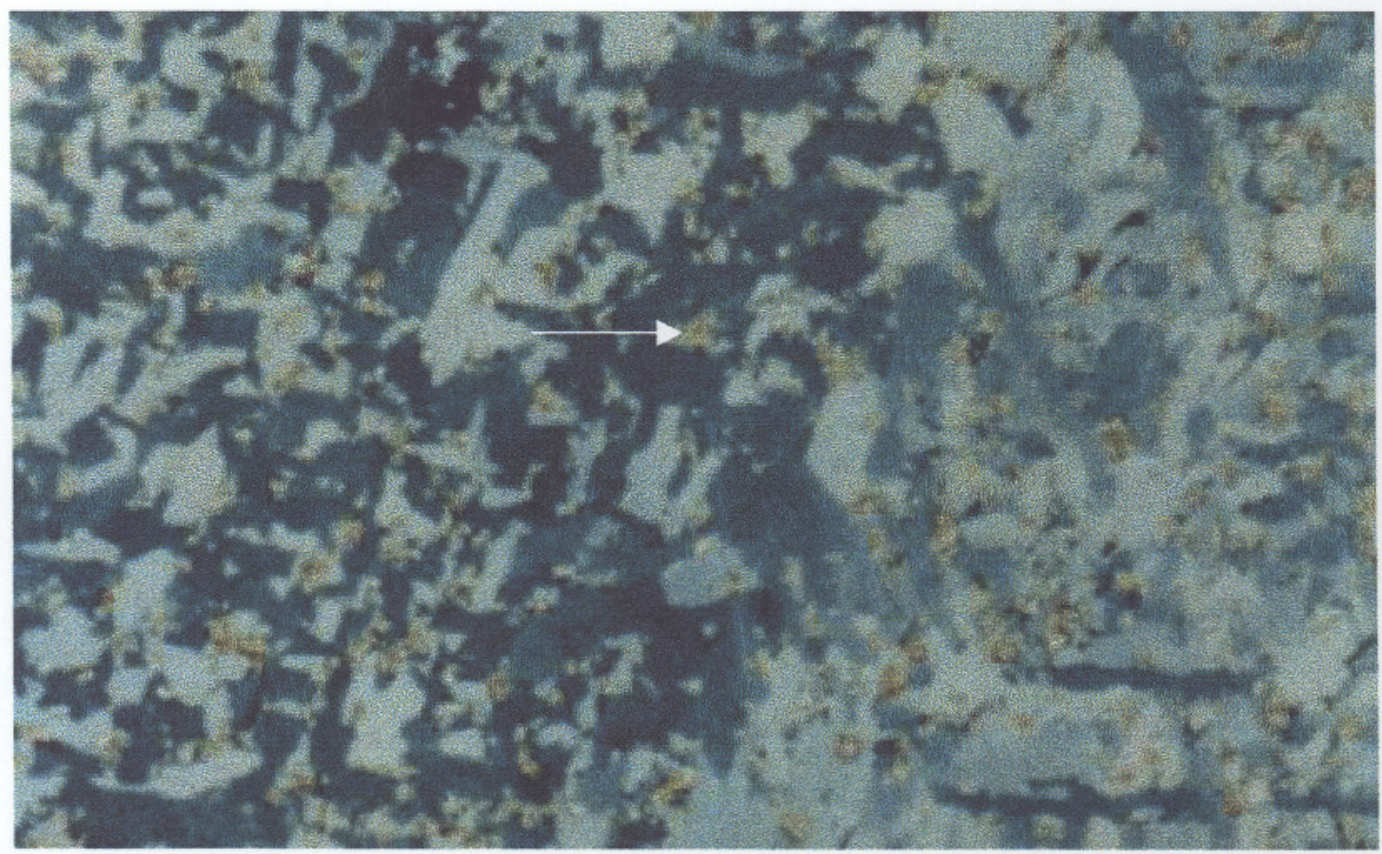

b) amostra $8 p 2$, teor de Austenita retida - 0,5\%

Figura 5.22 - Amostras 8p1(a) e 8p2 (b) 


\section{4 - Ensaios Mecânicos}

\subsection{1 - Ensaio de Dureza Vickers}

A tabela 5.6 apresenta os resultados médios das medidas de dureza.

\section{TABELA 5.6 - Dureza Vickers (HV)}

\begin{tabular}{l|l|l|l}
\hline & HV & \multicolumn{1}{c}{ HV } \\
\hline 1p3 & 206 & 1p2 & 233 \\
2p3 & 210 & 2p2 & 219 \\
3p3 & 202 & 3p2 & 215 \\
4p3 & 193 & 4p2 & 206 \\
5p1 & 199 & $\mathbf{5 p 2}$ & 194 \\
6p1 & 159 & $\mathbf{6 p 2}$ & 206 \\
7p1 & 216 & $\mathbf{7 p 2}$ & 213 \\
8p1 & 217 & $\mathbf{8 p 2}$ & 216 \\
\hline
\end{tabular}

\subsection{2 - Ensaio de Tracão}

TABELA 5.7 - Resultados do ensaio de tração a $-10^{\circ} \mathrm{C}(\mathrm{MPa})$

\begin{tabular}{|c|c|c|c|c|c|c|c|c|}
\hline & $1 \mathrm{p3}$ & $2 p 3$ & $3 p 3$ & $4 p 3$ & $5 p 1$ & $6 p 1$ & $7 p 1$ & $8 p 1$ \\
\hline$\sigma_{E}$ & 535 & 560 & 500 & 485 & 517 & 500 & 550 & 575 \\
\hline$\sigma_{R}$ & 702 & 670 & 655 & 612 & 620 & 650 & 710 & 690 \\
\hline$A(\%)$ & 14 & 16 & 22 & 22 & 21 & 21 & 18 & 21 \\
\hline \multirow[t]{2}{*}{$E(\%)$} & 35 & 39 & 40 & 39 & 37 & 39 & 35 & 40 \\
\hline & $1 \mathrm{p} 2$ & $2 \mathrm{p2}$ & $3 p 2$ & $4 p 2$ & $5 p 2$ & $6 \mathrm{p2}$ & $7 \mathrm{p} 2$ & $8 \mathrm{p2}$ \\
\hline$\sigma_{E}$ & 615 & 600 & 530 & 500 & 515 & 525 & 590 & 580 \\
\hline$\sigma_{R}$ & 710 & 682 & 642 & 602 & 612 & 637 & 677 & 655 \\
\hline$A(\%)$ & 17 & 18 & 20 & 23 & 22 & 20 & 19 & 19 \\
\hline$E(\%)$ & 39 & 41 & 41 & 39 & 41 & 40 & 39 & 39 \\
\hline
\end{tabular}




\subsection{3 - Ensaio de Impacto Charpy}

As figuras de 5.15 a 5.22 mostram as curvas representativas dos ensaios de impacto para os 16 cordões de solda.

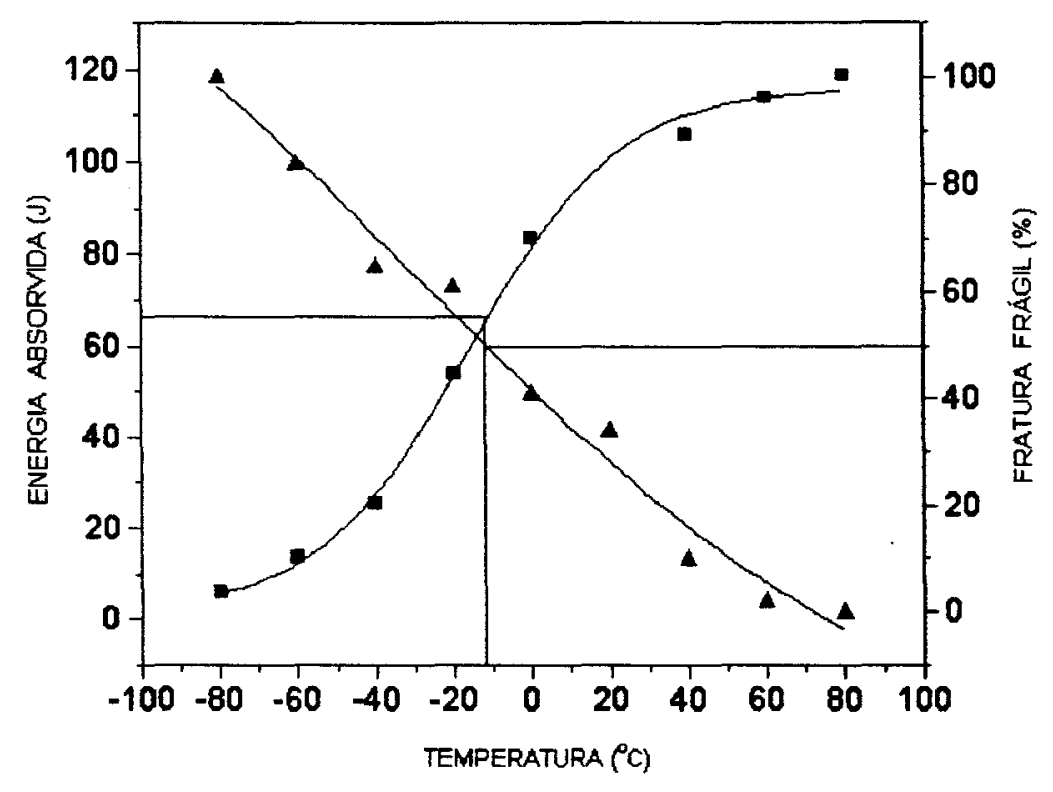

(a) amostra 1p2

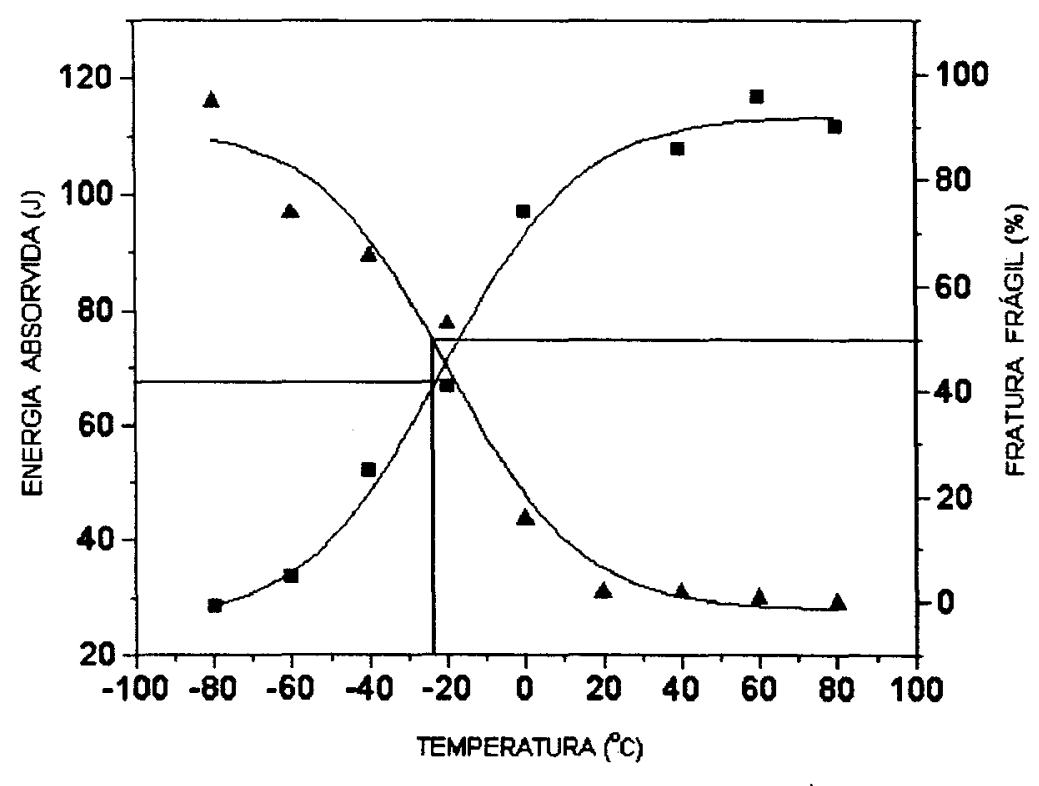

(b) amostra $1 p 3$

Figura 5.15 - Curvas de Energia Absorvida (ㅁ) e Porcentagem de Fratura Frágil $(\Delta)$ para as amostras $1 p 2(a)$ e $1 p 3(b)$ 


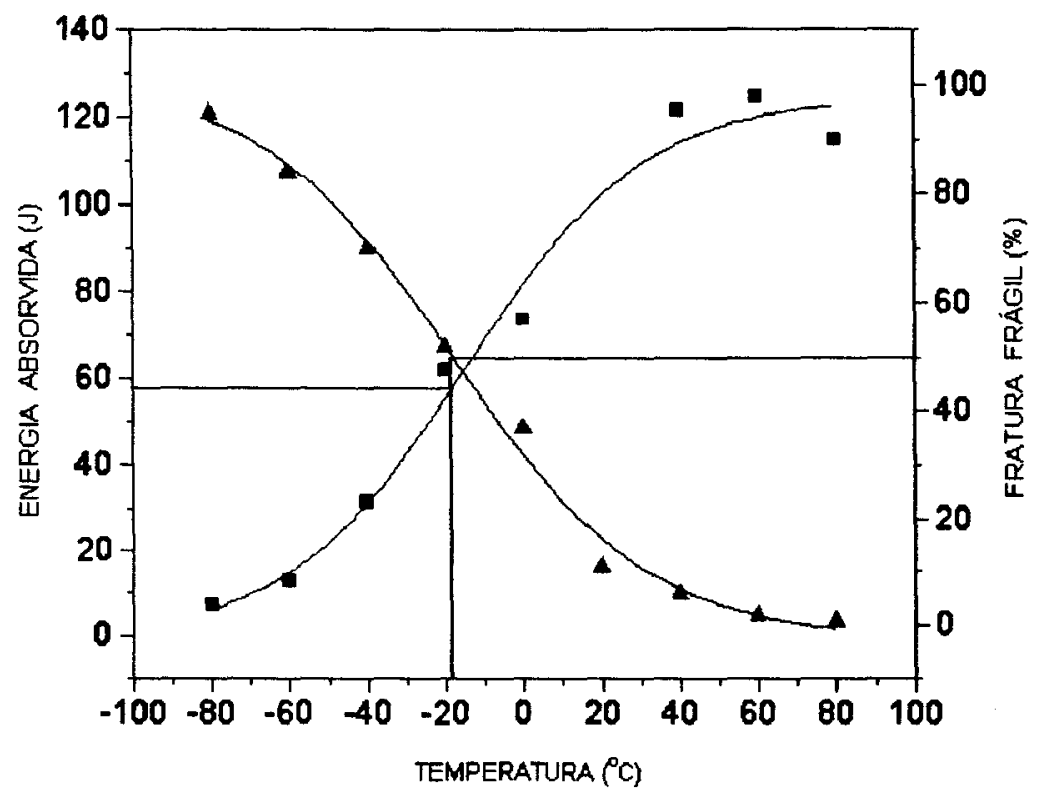

(a) amostra $2 \mathrm{p} 2$

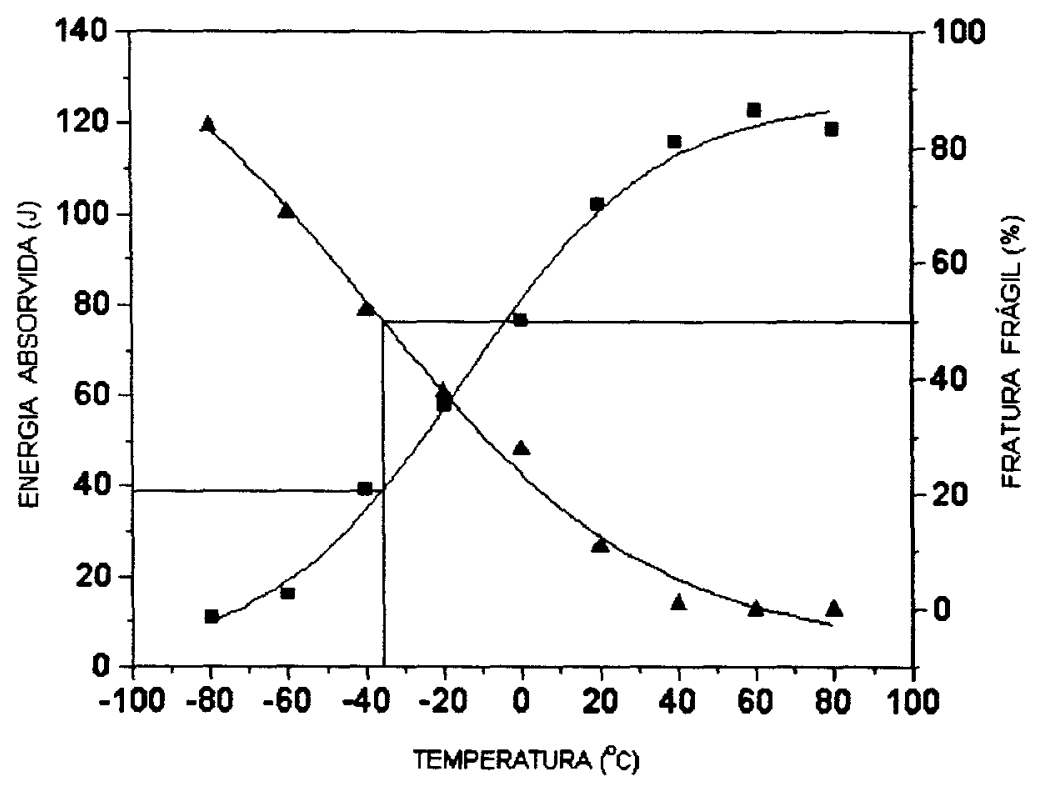

(b) amostra 2p3

Figura 5.16 - Curvas de Energia Absorvida (ㅁ) e Porcentagem de Fratura Frágil $(\Delta)$ para as amostras $2 p 2(a)$ e $2 p 3(b)$ 


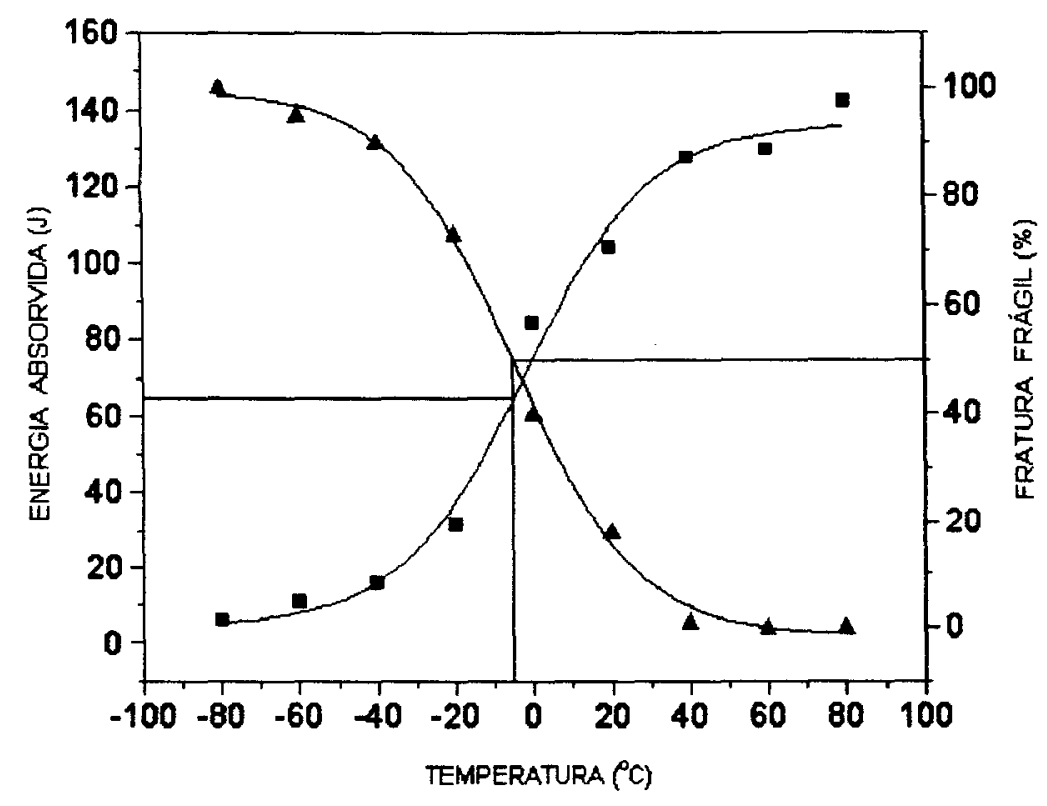

(a) amostra $3 p 2$

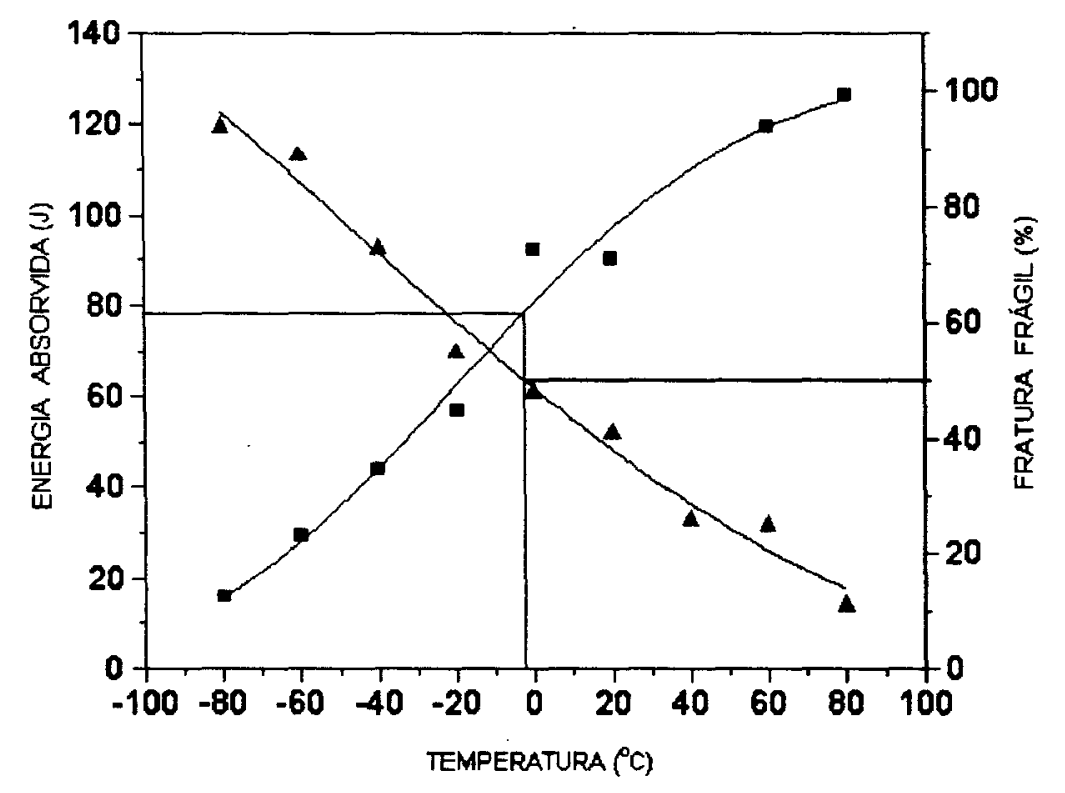

(b) amostra $3 p 3$

Figura 5.17 - Curvas de Energia Absorvida ( $\square$ ) e Porcentagem de Fratura Frágil $(\Delta)$ para as amostras $3 p 2(a)$ e $3 p 3(b)$ 


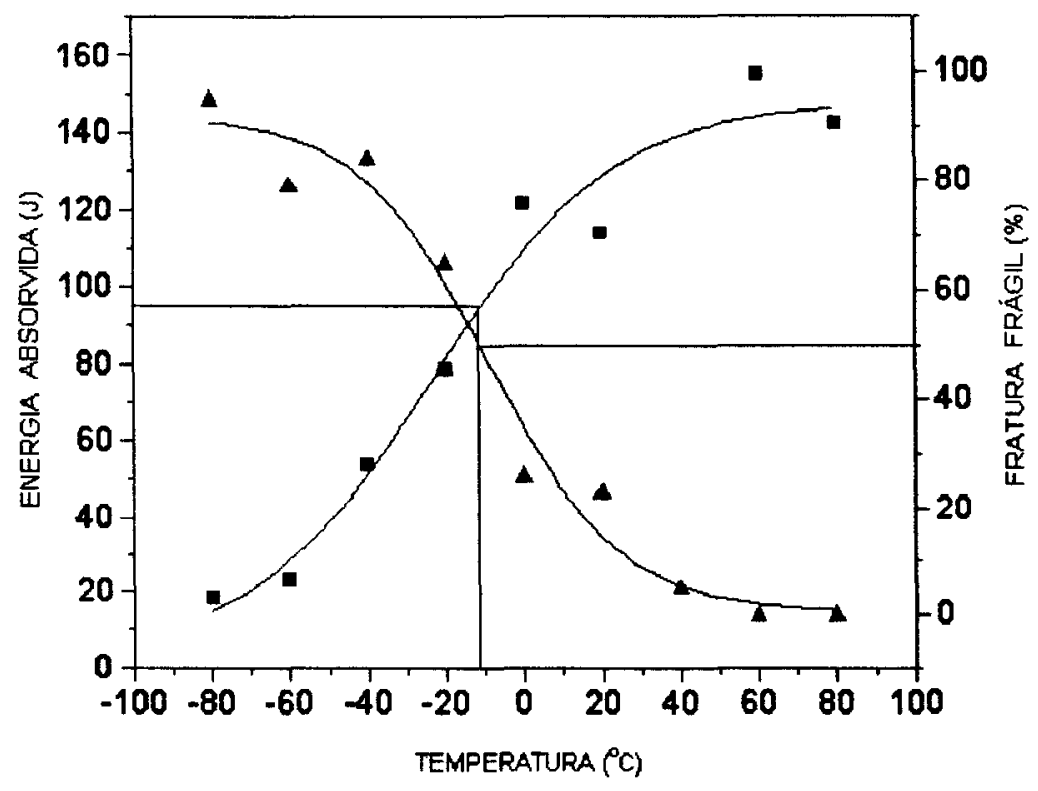

(a) amostra $4 p 2$

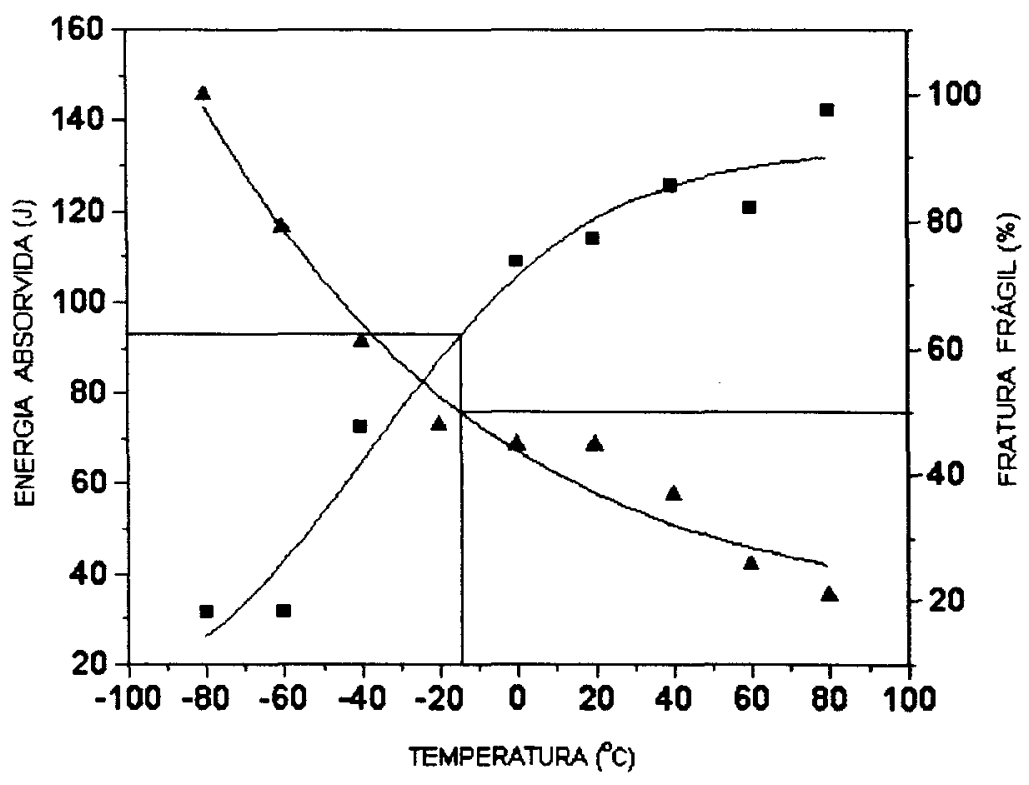

(b) amostra $4 p 3$

Figura 5.18 - Curvas de Energia Absorvida ( $\square$ ) e Porcentagem de Fratura Frágil $(\triangle)$ para as amostras $4 p 2$ (a) e $4 p 3(b)$ 


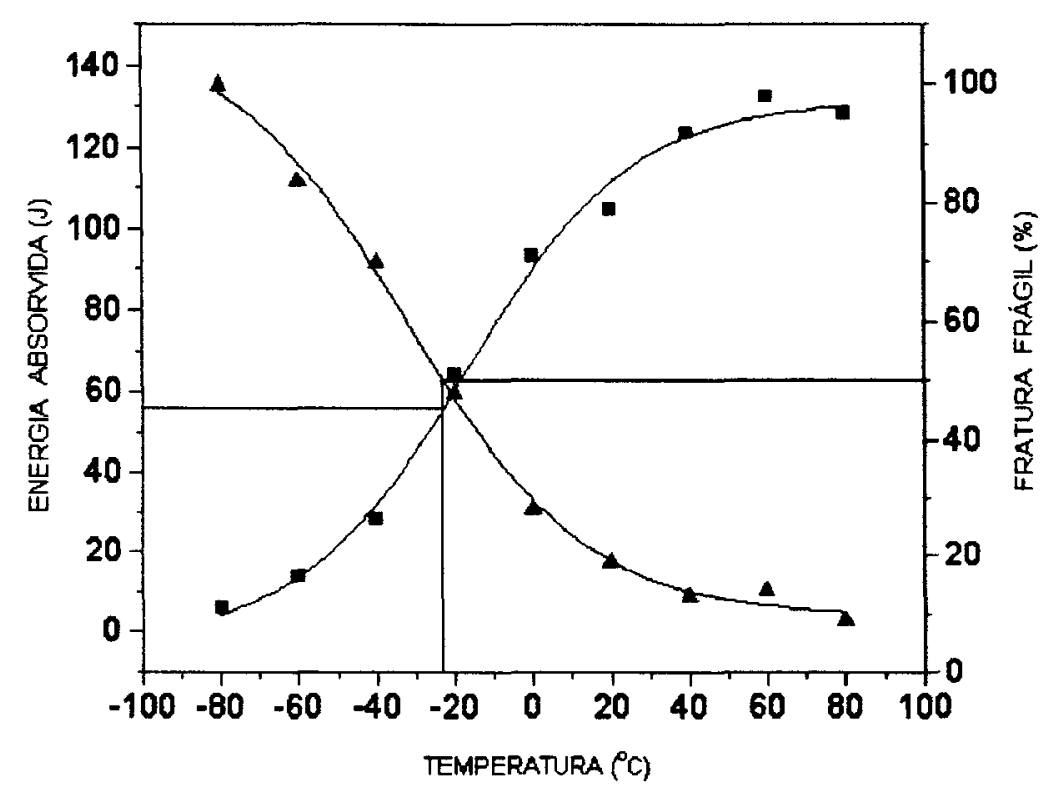

(a) amostra 5p2

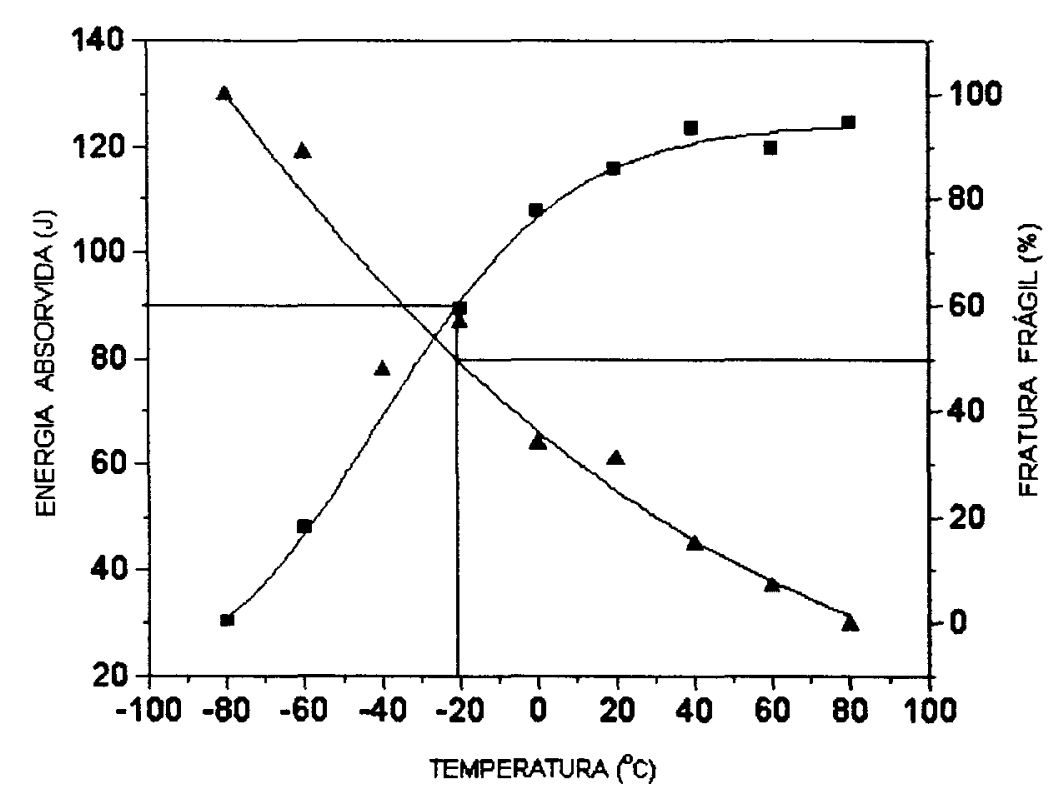

(b) amostra $5 p 1$

Figura 5.19 - Curvas de Energia Absorvida ( $\square$ ) e Porcentagem de Fratura Frágil $(\triangle$ )para as amostras $5 p 2$ (a) e $5 p 1(b)$ 


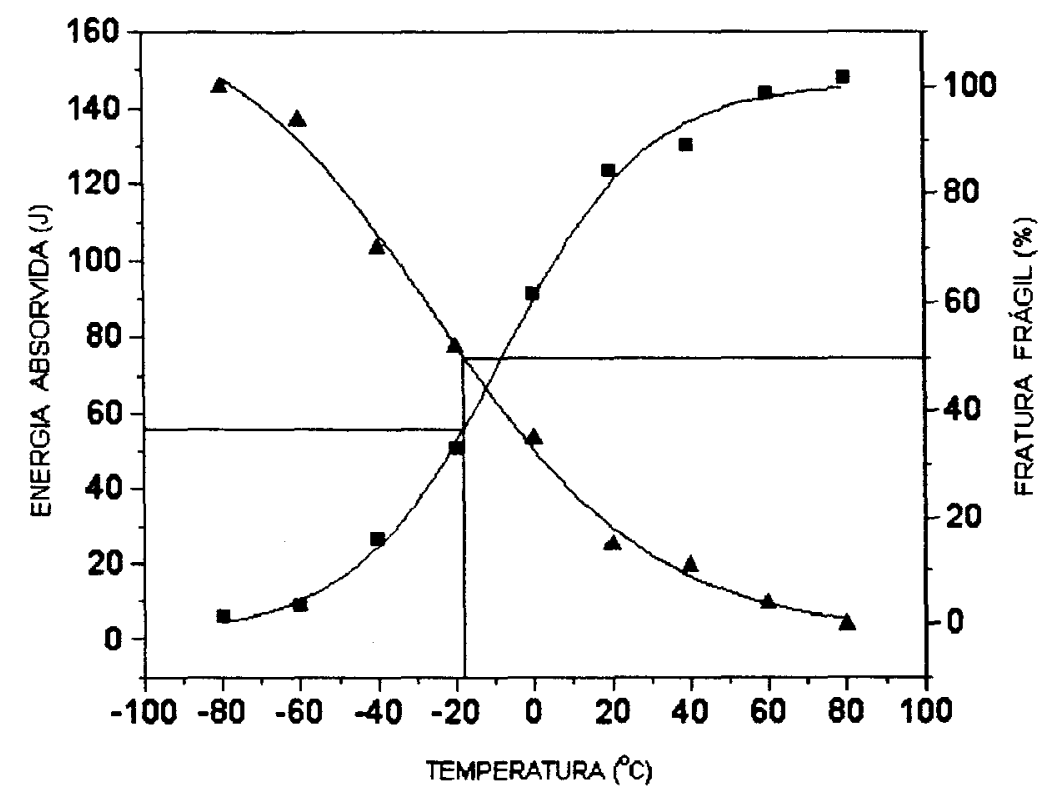

(a) amostra 6p2

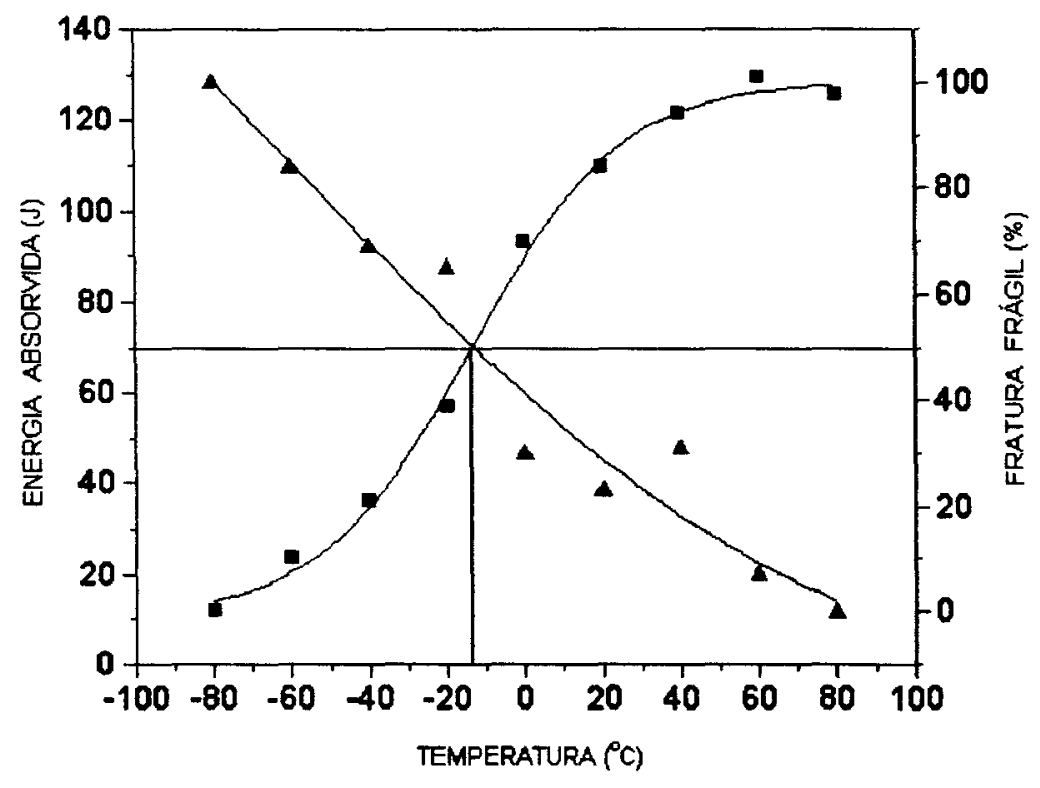

(b) amostra 6p1

Figura 5.20 - Curvas de Energia Absorvida ( $\square$ ) e Porcentagem de Fratura Frágil $(\Delta)$ para as amostras $6 p 2$ (a) e $6 p 1(b)$ 


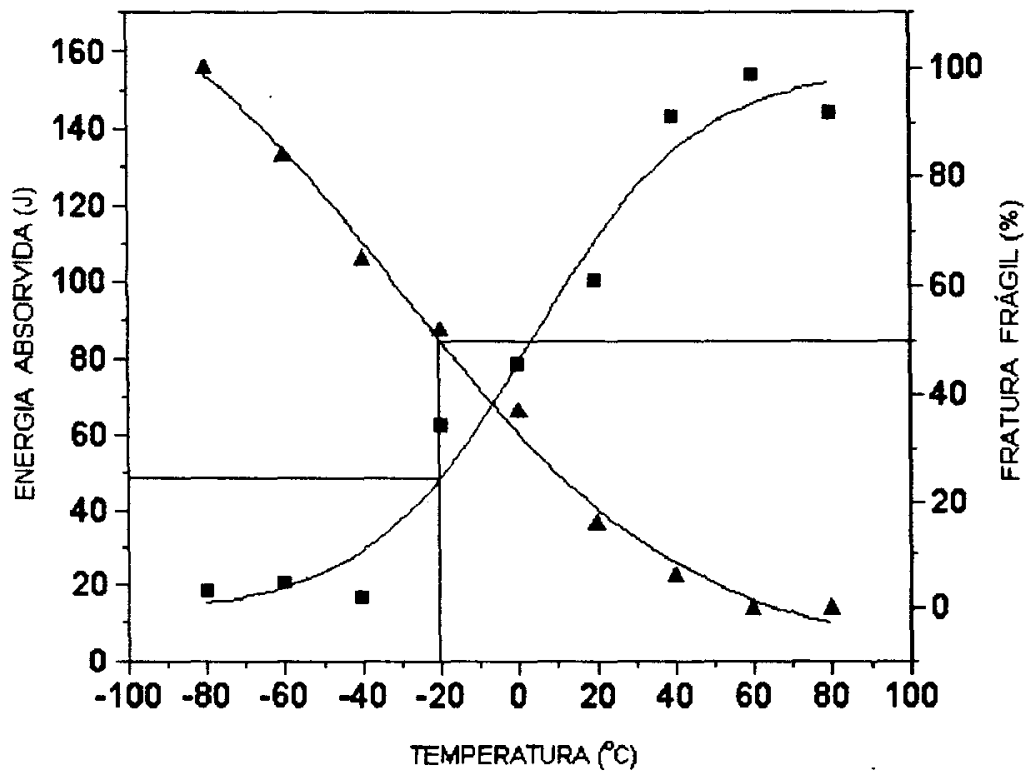

(a) amostra $7 \mathrm{p} 2$

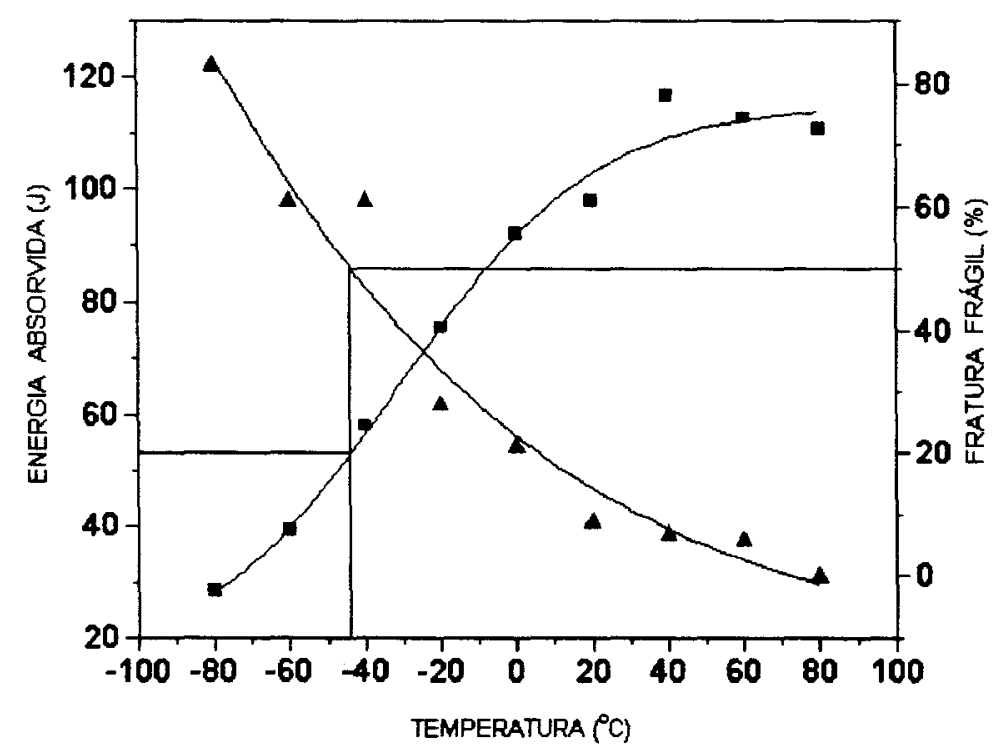

(b) amostra $7 p 1$

Figura 5.21 - Curvas de Energia Absorvida ( $\square$ ) e Porcentagem de Fratura Frágil $(\Delta)$ para as amostras $7 \mathrm{p} 2(\mathrm{a})$ e $7 \mathrm{p} 1$ (b) 


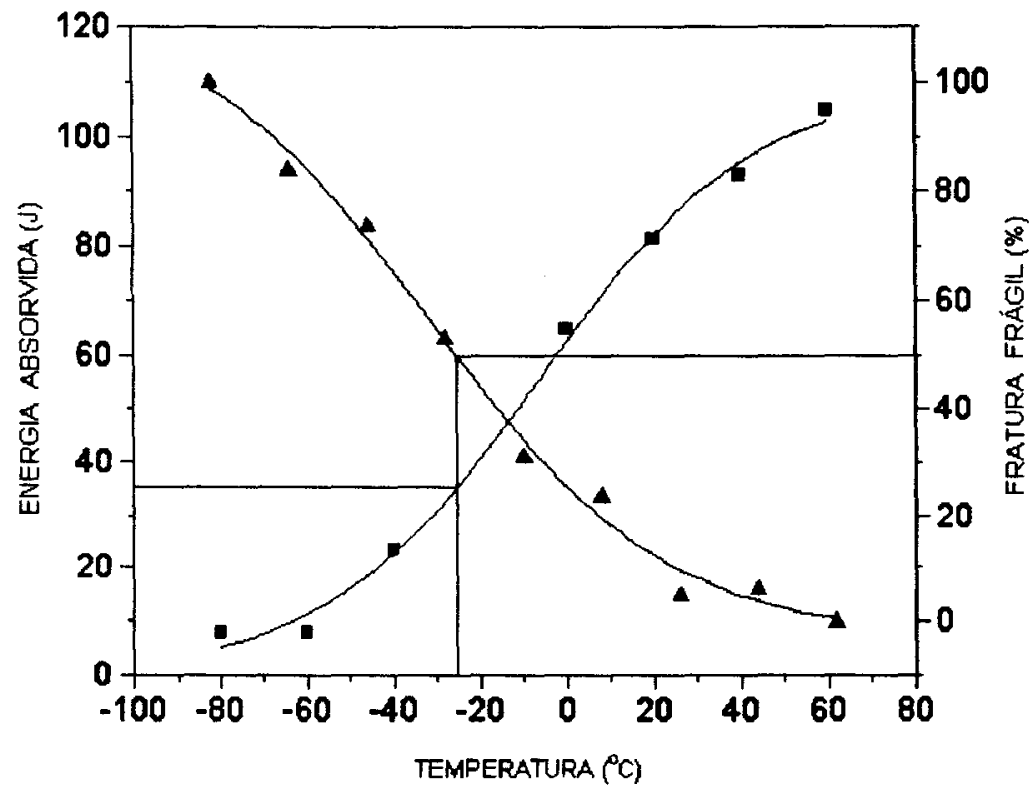

(a) amostra $8 p 2$

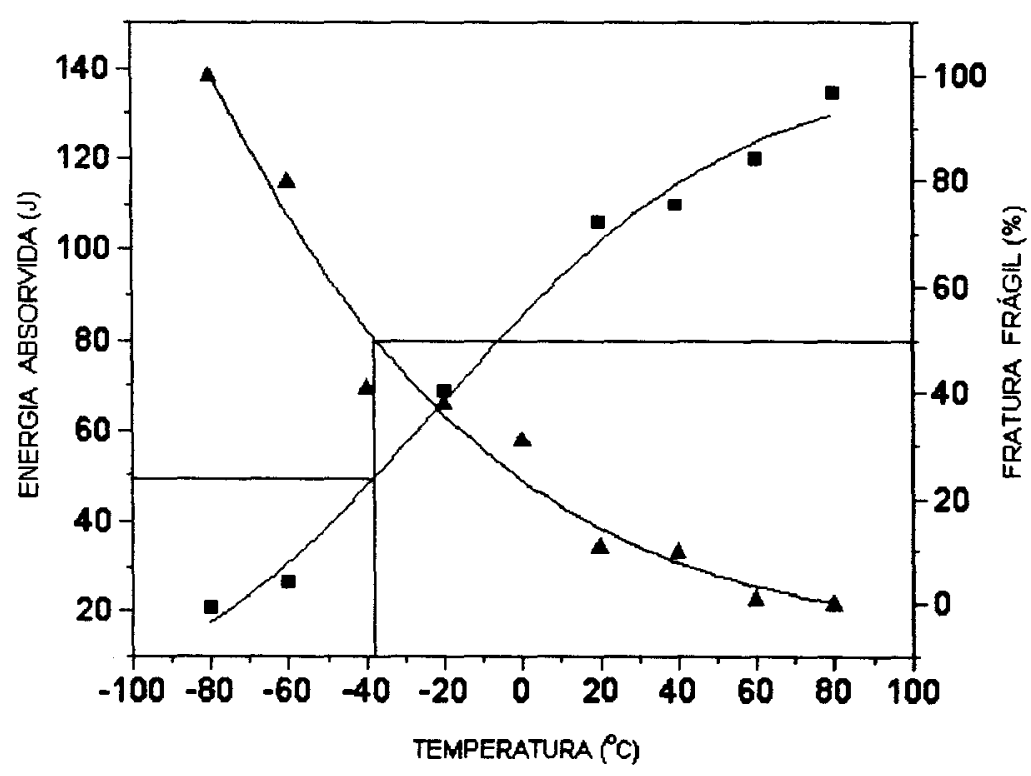

(b) amostra 8p1

Figura 5.22 - Curvas de Energia Absorvida ( $\square$ ) e Porcentagem de Fratura Frágil $(\triangle)$ para as amostras $8 p 2(a)$ e $8 p 1$ (b) 


\subsection{4 - C. T. O. D.}

A tabela 5.8 apresenta os resultados do ensaio de CTOD para os cordões ensaiados, 5P1 e 7P1, escolhidos através de suas características mecânicas e microestruturais.

TABELA 5.8 - Resultados do Ensaio de CTOD :

Carga Máxima, COD de Carga Máxima, $\vee p$, e $\delta_{m}$

\begin{tabular}{|c|c|c|c|c|}
\hline & Carga $(\mathrm{kN})$ & CTOD $(\mathrm{mm})$ & $\mathrm{Vp}(\mathrm{mm})$ & $\delta_{\mathrm{m}}(\mathrm{mm})$ \\
\hline Cordão $5 \mathrm{P} 1$ & 5.7 & 1.37 & 1,2 & 0,30 \\
\hline Cordão 7P1 & 6,9 & 1,00 & 0,8 & 0,22 \\
\hline
\end{tabular}

As figuras 5.23 e 5.24 apresentam os gráficos relativos aos ensaios dos cordões 5P1 e 7P1, respectivamente.

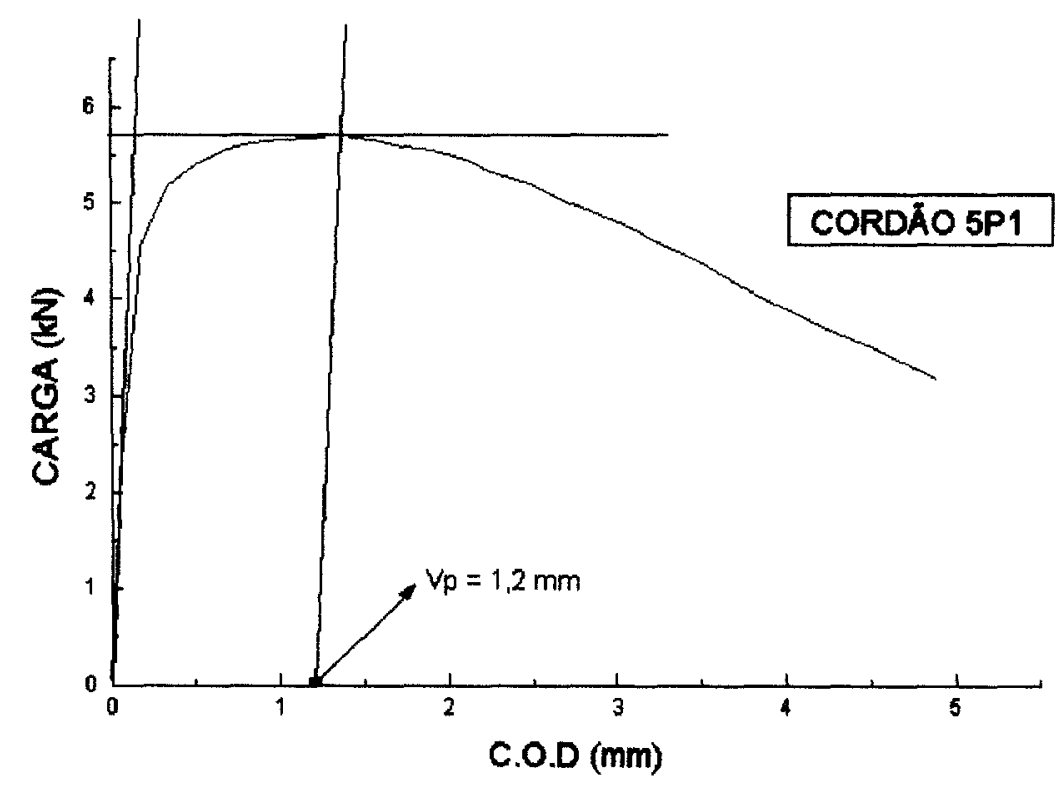

Figura 5.23 - Curva de ensaio CTOD - Carga x COD cordão de solda 5P1 


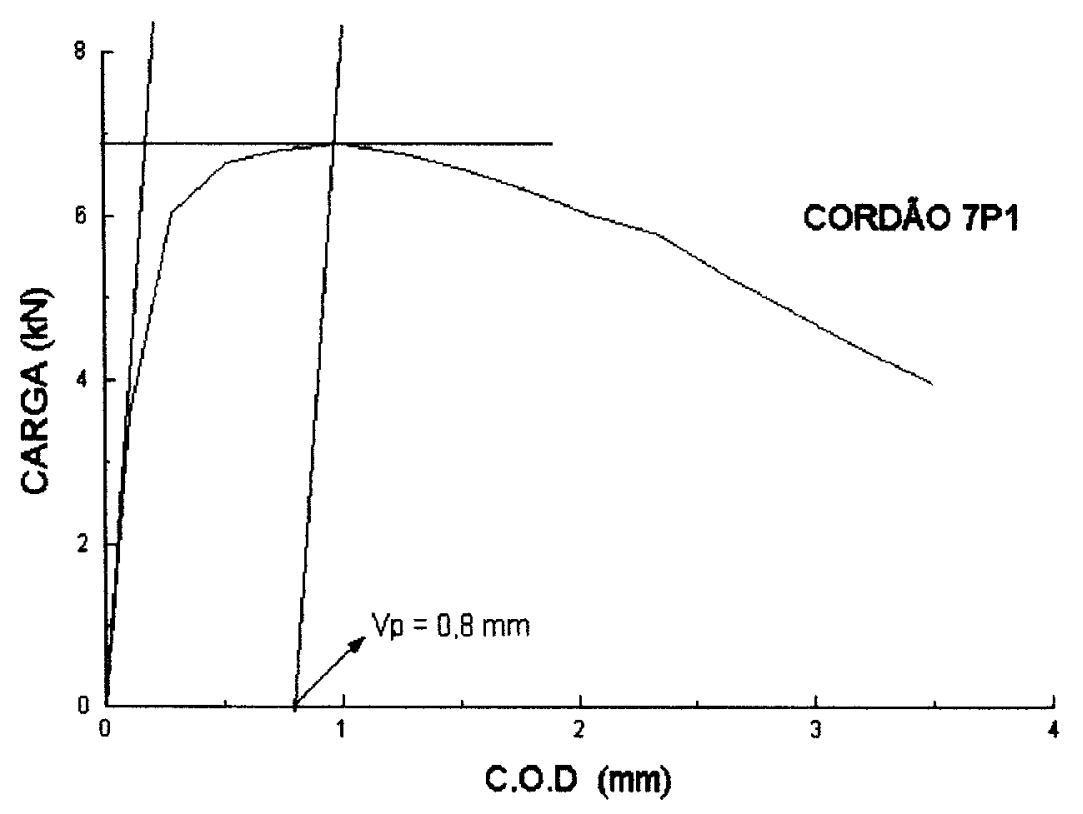

Figura 5.24 - Curva de ensaio CTOD - Carga x COD cordão de solda 7P1 


\section{6 - DISCUSSÃO}

\section{1 - Composicão Química}

Utilizou-se as tabelas 5.1 e 5.2 para a análise das composições químicas dos cordões de solda.

Os teores de carbono não variaram significativamente entre os pares de cordões de mesma combinação arame-fluxo, quais sejam, cordões 1-7, 2-8, 3-6 e 4-5, mostrando que o aporte de calor não teve influencia nesse aspecto.

Entre os cordões obtidos com mesmo eletrodo, os realizados com fluxo BX-200 apresentaram teores de $\mathrm{C}$ um pouco maiores em relação àqueles realizados com fluxo OK-1071, uma variação de $30 \%$ para o eletrodo EM-12K e 12,5\% para o eletrodo EB-2.

Entre os cordões obtidos com mesmo fluxo, os realizados com fluxo OK-1071 não apresentaram variação entre os eletrodos EM-12K e EB-2. Para os realizados com fluxo BX-200, os obtidos a partir do eletrodo EM-12K apresentaram um teor de $\mathrm{C}$ cerca de $20 \%$ maior que os obtidos com EB-2.

Os teores de $\mathrm{Cr}$ variaram em média $10 \%$ com relação aos aportes de calor, entre os pares de cordões de mesma combinação aramefluxo. As variações foram de $7 \%$ para os cordões $1-7,5 \%$ para os cordões $2-8,11 \%$ para os cordões $3-6$ e $16 \%$ para os cordões $4-5$, todos no sentido de maiores teores para os maiores aportes. Os cordões elaborados com eletrodo EM-12K ( 3,4,5 e 6 ) se mostraram mais sensiveis quanto a essa variação.

Para os cordões obtidos com mesmo eletrodo a variação de fluxo não ocasionou variação significativa nos teores de $\mathrm{Cr}$. 
Entre os cordões obtidos com o mesmo fluxo, houve uma variação média de $70 \%$ no sentido de maiores teores de $\mathrm{Cr}$ para os cordões obtidos a partir do eletrodo EB-2, o que está relacionado com o maior teor de $\mathrm{Cr}$ nesse eletrodo ( $1,28 \%)$ em relação ao eletrodo EM-12K $(0,02 \%)$.

Para os teores de $\mathrm{Mn}$, os pares de mesma combinação arame-fluxo não apresentaram variação significativa quanto aos aportes de calor $(\sim 2 \%)$.

Entre os cordões obtidos com o mesmo eletrodo aqueles realizados com o fluxo BX-200 apresentaram teores de Mn cerca de $10 \%$ maiores que aqueles realizados a partir do fluxo OK-1071.

Para os cordões obtidos com o mesmo fluxo, aqueles realizados com o eletrodo EM-12K apresentaram teores de Mn cerca de $10 \%$ maiores, devido ao maior teor de $\mathrm{Mn}$ nesse tipo de eletrodo, em relação ao eletrodo EB-2.

Em relação ao Mo, os pares de mesma combinação aramefluxo não apresentaram variação significativa ( $\sim 2 \%$ ), portanto o aporte de calor não influenciou esses teores.

Para os cordões obtidos com mesmo eletrodo não houve variação significativa entre os dois fluxos $(\sim 2 \%)$.

Entre os cordões obtidos com o mesmo fluxo aqueles realizados com o arame EB-2 apresentaram um teor maior devido à presença do Mo nesse eletrodo (o eletrodo EM-12K não apresenta esse elemento), enquanto que para as combinações com EM-12K os teores de Mo representam a quantidade de Mo da chapa base.

Os teores de oxigênio nos cordões de solda ficaram bem acima do teor de oxigênio da chapa base. Os cordões feitos a partir do fluxo OK-1071 apresentaram um teor de oxigênio mais elevado do que os 
cordões feitos com o fluxo BX-200 mostrando que o fluxo BX-200 tem um poder de desoxidação maior em relação ao OK-1071 e isto devido ao fluxo BX-200 possuir na sua composição um maior teor de silício e titânio , que são fortes desoxidantes. $O$ teor de oxigênio nos cordões foi inversamente proporcional ao teor de $\mathrm{Mn}$, demonstrando também o poder desoxidante desse elemento.

\section{2 - Diluicão e Macrografias}

A diferença nos aportes de calor , 3,6 e 4,2 KJ/mm não acarretaram variação significativa na diluição da chapa base, de modo que a diluição foi praticamente a mesma para as oito condições, cerca de $36 \%$, - que pode ser notado pelo aspecto dos cordões de solda nas macrografias, onde nota-se que os cordōes apresentam perfis muito próximos mesmo com a diferença no aporte de calor, observando-se também o mesmo nível de penetração.

A interação entre chapa base e consumiveis é determinada pela diluição, como se pode observar pelo comportamento das composições químicas dos cordões de solda em relação à composição química da chapa base, essa interação, em todas as oito condições comportou-se como esperado.

\section{3 - Microestrutura}

As quantificações de fase e microfase são apresentadas nas tabelas 5.6 e 5.7 .

Esperava-se uma maior porcentagem de ferrita acicular nos cordões com maior teor de Mn, conforme EVANS (1980), FARRAR e HARRISON (1987) e SVENSSON e GRETOFT (1990). Porém , o uso do pó metálico promove reações exotérmicas na poça de fusão, segundo 
SOUZA (1991). Essas reações exotérmicas aumentam a temperatura na poça de fusão, diminuindo a velocidade de resfriamento da solda. Conseqüentemente, há um aumento da temperatura de transformação favorecendo a formação de ferrita primária em vez da ferrita acicular.

Os cordões obtidos a partir do eletrodo EB-2 $(1,2,7$ e 8$)$ apresentaram uma porcentagem maior de ferrita acicular em relação àqueles obtidos a partir do eletrodo $\operatorname{EM}-12 \mathrm{~K}(3,4,5$ e 6$)$, o que está relacionado com a maior temperabilidade do eletrodo EB-2.

Observando-se as composições químicas, constata-se que esses cordões feitos com EB-2 apresentaram maiores teores de Mo e N. De acordo com EVANS (1988) o Mo promove a formação de ferrita acicular até o teor de $0,5 \%$ (os teores se encontram na faixa de 0,15 a $0,16 \%$ ). Segundo LAU et al. (1988) $\circ \mathrm{N}$ tem efeito para teores acima de $70 \mathrm{ppm}$ que é o caso dos cordões feitos com EB-2, entre 74 e 78 ppm.

Com relação ao aporte de calor, para os cordões obtidos com EB-2 aqueles de maior aporte apresentaram maiores porcentagens de ferrita acicular (diferença de cerca de 15\%), nos cordōes obtidos a partir do eletrodo EM-12K não se observou essa tendência.

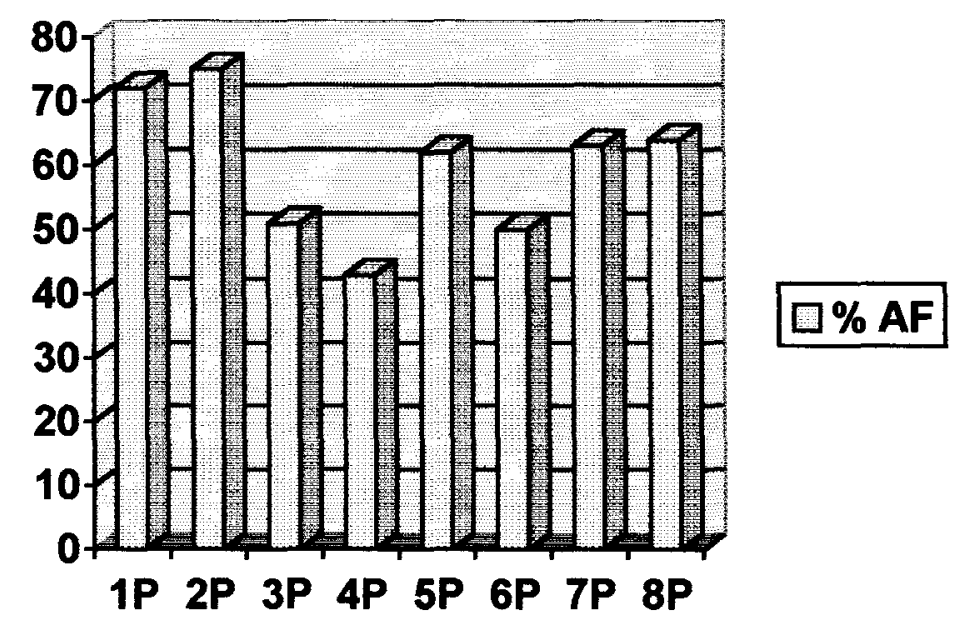

FIGURA 6.1 - Porcentagem de ferrita acicular (AF) para os oito cordões de solda como soldados . 


\section{4 - Microfase}

A microfase está presente em todos os cordões de solda como soldados. Esta fase não é tingida pelo Klemm I, assim ela aparece branca, revelando-se como austenita, de acordo com WECK e LEISTNER (1982). Observa-se que a austenita retida está entre os contornos de ferrita acicular e entre a ferrita de segunda fase alinhada. A identificação dessa fase, neste trabalho, toma como referência, além do fato já citado do tingimento pelo ataque colorido, os trabalhos de SVENSSON e GRETOFT (1991), KOBAYASHI (1994), ALMQVIST et al. (1972) que citaram esta microfase como sendo austenita retida. A morfologia da austenita retida deste trabalho é a mesma dos trabalhos de referência.

Como tem-se adição de pó metálico em todas as condições , e como já foi citado, essa adição promove uma velocidade de resfriamento baixa, devido às reações exotérmicas da poça de fusão. Velocidades de resfriamento maiores favorecem a formação de austenita retida e/ou martensita-austenita, segundo GLOVER et al. (1977), dessa forma neste trabalho observa-se uma menor quantidade de austenita retida nos cordóes como soldados em relação à trabalhos anteriores, sem adição de pó metálico.

A mudança do fluxo de BX-200 para OK-1071 provocou uma diminuição na porcentagem de austenita retida, tanto para os cordões obtidos a partir do eletrodo EB-2 como para os obtidos a partir do eletrodo EM-12K. Os cordões 1, 3, 6 e 7 apresentaram uma maior porcentagem de austenita retida em relação aos cordões $2,4,5$ e 8 conforme a figura 6.2. Nota-se que os cordões feitos com o fluxo BX-200 (1,3,6 e 7) possuem um maior teor de carbono em relação aos cordões feitos com o fluxo OK1071 (2,4,5 e 8). O aumento no teor desse elemento favorece a formação de austenita retida de acordo com SVENSSON e GRETOFT (1991). Durante a transformação $\gamma \rightarrow \alpha$ devido a formação de ferrita, ocorre $\circ$ 
enriquecimento de carbono da austenita não transformada. Dependendo da taxa de resfriamento e da composição química esta austenita enriquecida de carbono pode transformar-se em uma variedade de microconstituintes como perlita, bainita, martensita ou ficar retida, segundo GRONG e MATLOCK (1986).

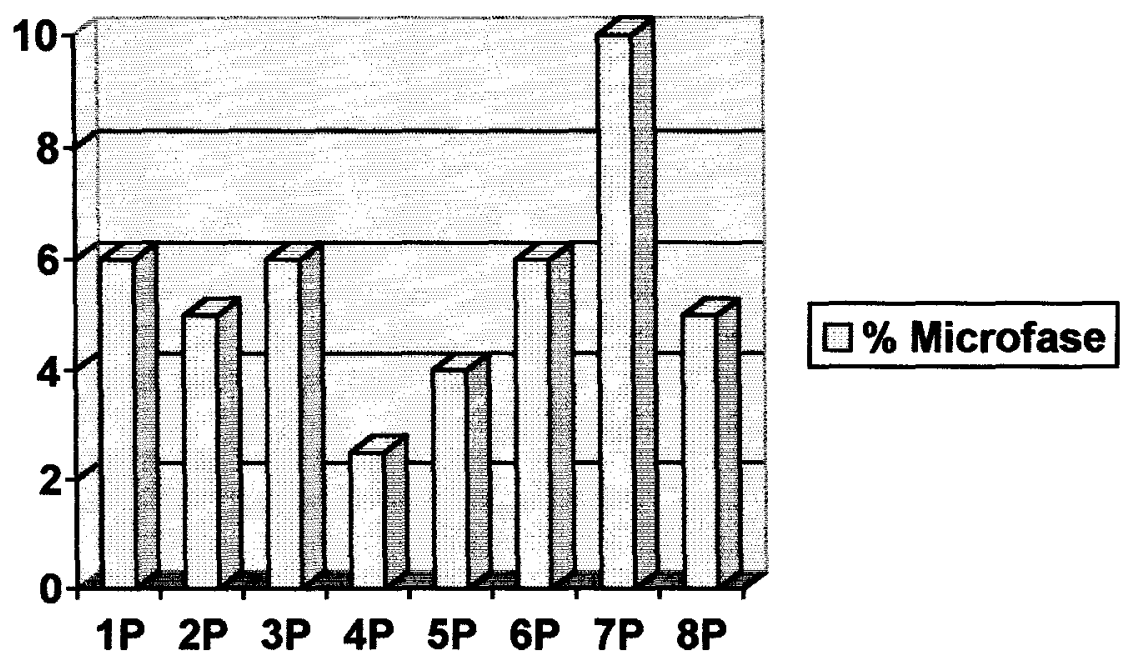

FIGURA 6.2 - Porcentagem de austenita retida para os oito cordões de solda como soldados

Visto que as propriedades mecânicas do metal de solda são função da combinação dos seus diferentes microconstituintes, a presença da austenita retida poderá induzir fragilização promovendo queda na tenacidade ao impacto, por facilitarem a propagação de trincas por clivagem. 


\section{5 - Propriedades Mecânicas}

\subsection{1 - Dureza}

Observa-se pela tabela 5.3 que os cordões de solda obtidos a partir do eletrodo EB-2 (1,2,7 e 8) apresentaram uma dureza maior em relação aos cordões obtidos a partir do eletrodo EM-12K (3,4,5 e 6). Isto é devido aos cordões obtidos a partir de EB-2 apresentarem uma maior porcentagem de ferrita acicular em relação aos elaborados com eletrodo EM-12K.

A maior porcentagem de elementos de liga nos cordões obtidos a partir do eletrodo EB-2 provoca também o endurecimento por solução sólida da matriz ferrítica.

Entre os cordões obtidos pelo eletrodo EB-2 aqueles de menor aporte apresentaram dureza cerca de $5 \%$ maior em relação àqueles de maior aporte .Tal fato deve-se, possivelmente, aos efeitos do $\mathrm{Cr}$, Mo e Cu em solução sólida e a presença de austenita retida entre os grãos da ferrita acicular.

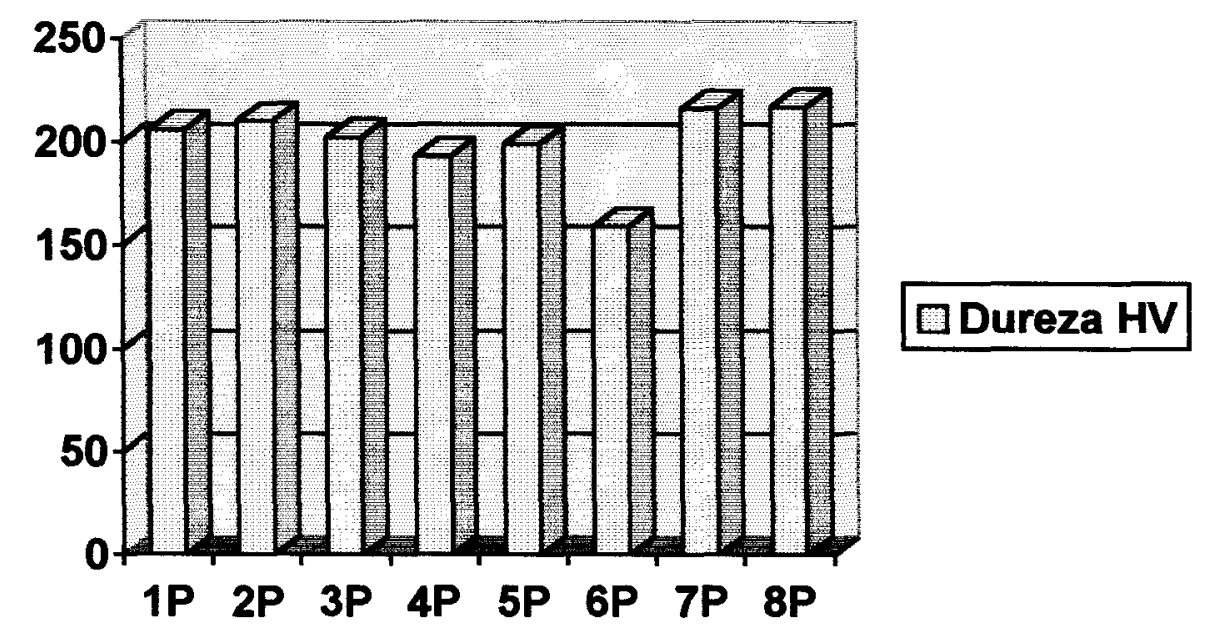

FIGURA 6.3 - Dureza Vickers para os oito cordões de solda como soldados 


\subsection{2 - Tracão}

De acordo com a equação de Hall-Petch :

$$
\sigma_{e}=\sigma_{i}+k d^{\frac{-1}{2}}
$$

onde:

$\sigma_{\varepsilon}=$ tensão de escoamento

$\sigma_{1}=$ tensão de atrito que se opõe ao movimento de discordâncias

$\mathrm{k}$ = constante que representa uma medida da extensão do empilhamento de discordâncias nas barreiras d = diâmetro do grão

- limite de escoamento pode ser aumentado pelo acréscimo da tensão de atrito. Isto pode ser feito pela introdução de elementos de liga

(em solução sólida e/ou precipitados) na matriz do material, os quais interferem na movimentação das discordâncias.

A alteração da velocidade de resfriamento tem grande importância nas propriedades mecânicas do metal depositado. Uma velocidade de resfriamento mais lenta e dependendo da temperabilidade do material, tende a favorecer uma microestrutura mais grosseira e a precipitação. E se for rápida, tenderá a manter os elementos de liga em solução sólida e reduzir a quantidade de ferrita proeutetóide, de acordo com KOBAYASHI (1995).

Uma maior porcentagem de ferrita acicular confere melhores propriedades de tração, conforme FARRAR e HARRISON (1987).

Conforme a tabela 5.4 os cordões obtidos a partir do eletrodo EB-2 (1,2,7 e 8) apresentaram um limite de escoamento maior em relação aos cordões obtidos com o eletrodo EM-12K (3,4,5 e 6). 
Como já foi dito no item sobre dureza, o eletrodo EB-2 apresenta uma maior porcentagem de elementos de liga, o que provoca nos cordões $1,2,7$ e 8 um endurecimento maior da matriz ferrítica por solução sólida. É sabido que a dureza tem relação direta com as propriedades de tração.

Entre os cordōes obtidos com EB-2, aqueles elaborados com fluxo OK-1071 apresentaram um limite de escoamento maior que aqueles a partir do fluxo BX-200 (cerca de 5\%).

Para as mesmas combinações arame-fluxo elaboradas com EB-2, aquelas de menor aporte , 7 e 8 , apresentaram um limite de escoamento cerca de 2,5\% maior que aquelas de maior aporte, 1 e 2, o mesmo acontecendo com os cordões de mesma combinação arame-fluxo elaborados com o eletrodo EM-12K, sendo que para os cordões 3 e 6 , o limite de escoamento foi o mesmo e para os cordões 4 e 5 a diferença foi de cerca de $6 \%$.

Tal resultado é coerente com a conclusão apresentada por EVANS (1982) em que metais de solda com mesmos teores de $\mathrm{Mn}$ e C (mesmas temperabilidades) apresentaram menores limites de escoamento com o aumento do insumo de calor. Os cordões 7 e 8 apresentaram uma quantidade de ferrita acicular um pouco menor que os cordões 1 e 2 . Porém devido a maior velocidade de resfriamento, sua microestrutura é mais refinada, o que justifica seu maior limite de escoamento.

Já nos metais de menores temperabilidades $(3,4,5$ e 6$)$ observa-se que 0 limite de escoamento dos cordões 5 e 6 , de maior velocidade de resfriamento, é superior aos cordōes 3 e 4 , o que é coerente com sua microestrutura mais refinada, com maior teor de ferrita acicular. 


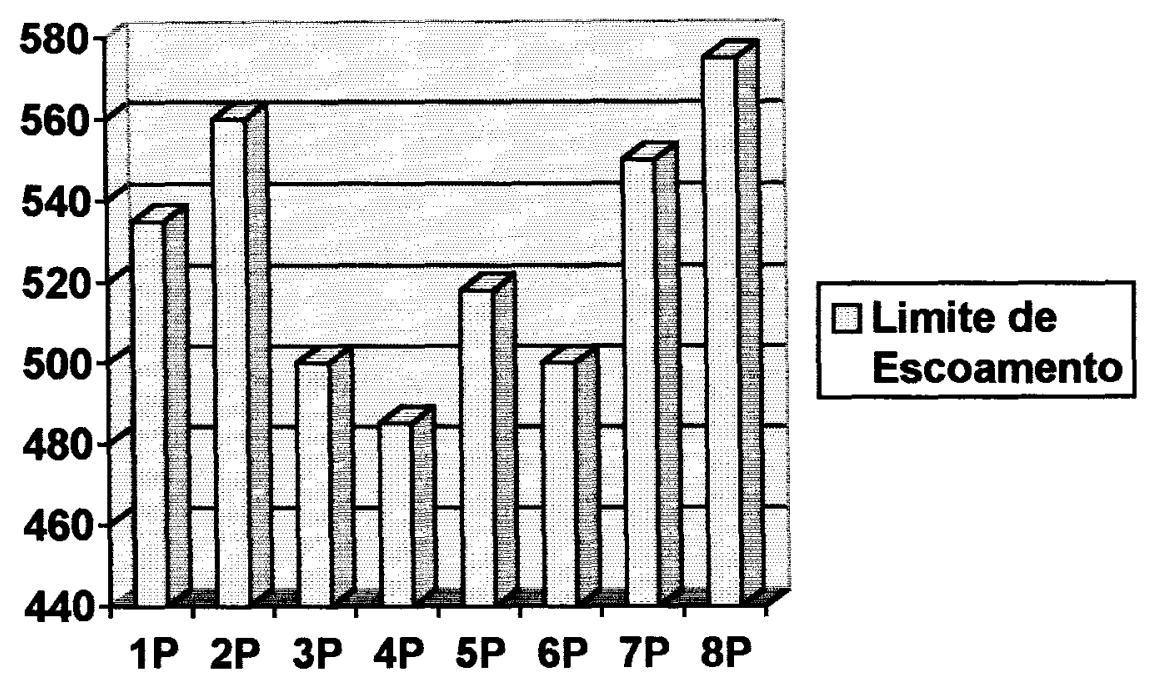

FIGURA 6.4 - Limites de escoamento para os oito cordões como soldados

\subsection{3 - Impacto}

A tabela 6.1 traz os resultados a partir dos gráficos do ensaio de impacto Charpy, quais sejam, temperatura AFTT, patamar de energia dúctil e temperatura para $28 \mathrm{~J}$.

TABELA 6.1 - Resultados do ensaio de impacto Charpy

\begin{tabular}{|c|c|c|c|c|c|c|c|c|}
\hline & $1 \mathrm{P}$ & $2 \mathrm{P}$ & $3 \mathrm{P}$ & $4 \mathrm{P}$ & $5 \mathrm{P}$ & $6 \mathrm{P}$ & $7 \mathrm{P}$ & $8 \mathrm{P}$ \\
\hline AFTT $\left({ }^{\circ} \mathrm{C}\right)$ & -23 & -36 & -3 & -14 & -21 & -14 & -44 & -38 \\
\hline Patamar(J) & 114 & 123 & 126 & 132 & 124 & 128 & 114 & 131 \\
\hline $28 \mathrm{~J}\left({ }^{\circ} \mathrm{C}\right)$ & -79 & -48 & -64 & -82 & -88 & -50 & -85 & -64 \\
\hline
\end{tabular}

Pode-se observar pela tabela 6.1 , em comparação com a tabela 5.6, que não há uma relação entre a porcentagem de ferrita acicular e o patamar dúctil. A porcentagem de ferrita acicular não influencia no patamar de energia dúctil , mas modifica a inclinação da curva de energia absorvida, conforme AKSELSEN e GRONG (1992). 


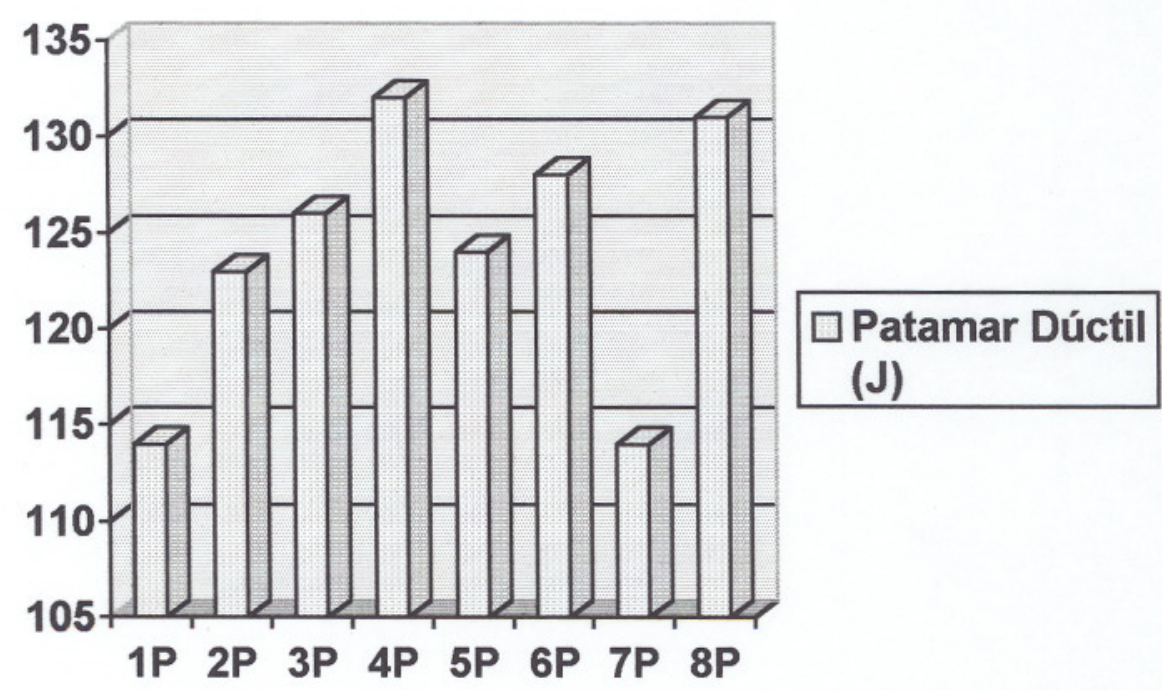

FIGURA 6.5 - Patamar de energia dúctil para os oito cordões como soldados

A figura 6.6 mostra as curvas apresentadas por FARRAR (1976) mostrando a correlação entre o teor de oxigênio e a energia no patamar de energia dúctil do metal de solda obtidos por arco submerso.

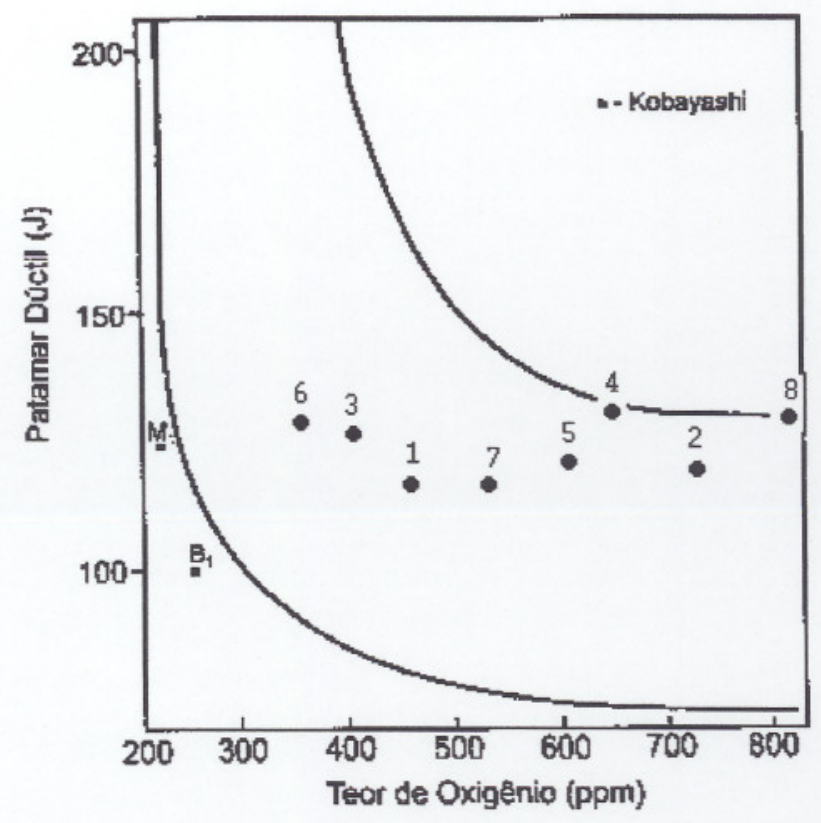

FIGURA 6.6 - Correlação da plataforma superior de energia Charpy com o teor de oxigênio no metal de solda (FARRAR, 1976) 
A energia no patamar de energia dúctil aumenta rapidamente com a diminuição do teor de oxigênio (300-400 ppm).

Os dados relativos a esse trabalho, relacionando teor de oxigênio com patamar de energia dúctil, foram sobrepostos à figura apresentada por FARRAR (1976), na figura 6.6, onde pode-se observar que os cordões que apresentaram um maior teor de austenita retida, quais sejam 1, 3, 6 e 7, apresentaram um patamar de energia dúctil mais baixo que o esperado pelo teor de oxigênio, essa alta porcentagem de austenita retida nesses cordões pode ter influenciado na queda do patamar de energia dúctil.

Os resultados de KOBAYASHI (1994), $\mathrm{M}_{1}$ e $\mathrm{B}_{1}$, cordões de solda de aço ARBL com condições de soldagem próximas deste trabalho, também foram sobrepostos à figura 6.6. Observa-se que o teor de oxigênio nas soldas $M_{1}$ e $B_{1}$ foram baixos devido ao fluxo utilizado, OP-121-TT, com índice de basicidade de 3,1. Com esses teores de oxigênio esperava-se patamares de energia dúctil mais elevados, através do trabalho de KOBAYASHI (1994) nota-se a grande quantidade de austenita retida desses cordões, quantidade que, visualmente, constata-se ser maior que a deste trabalho, o que leva à conclusão igual de que a austenita retida realmente pode ter causado a queda do patamar de energia dúctil.

A figura 6.7 mostra as curvas apresentadas por FARRAR e HARRISON (1987) mostrando a relação entre porcentagem de ferrita acicular e a temperatura de transição AFTT. Com o aumento na porcentagem de ferrita acicular no cordão de solda ocorre uma diminuição da AFTT.

Os dados deste trabalho relativos a porcentagem de ferrita acicular $e$ temperatura AFTT foram sobrepostos à curva apresentada por FARRAR e HARRISON (1987). 


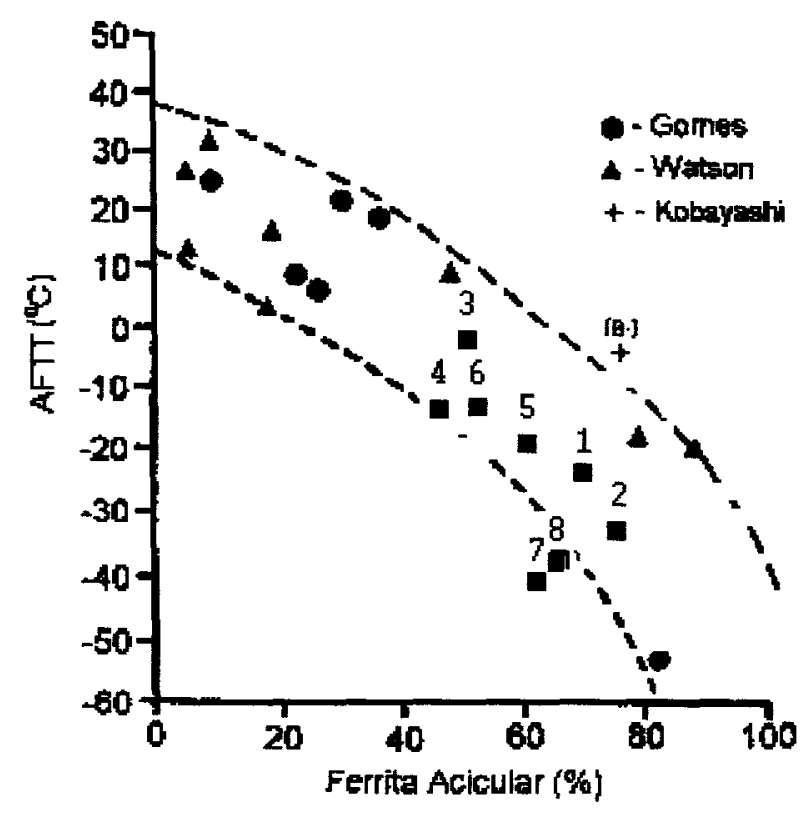

FIGURA 6.7 - Variação da AFTT com a proporção de ferrita acicular para metal de solda de aços C-Mn-Nb (FARRAR e HARRISON, 1987)

Comparando-se os metais depositados elaborados com eletrodo EB-2 (de maior temperabilidade) 1, 2, 7 e 8 como soldados, observa-se que a temperatura de transição é menor nos cordões 7 e 8 (menor aporte), que teve maior velocidade de resfriamento e uma menor quantidade de ferrita acicular. Tal fato deve-se, possivelmente, aos efeitos do $\mathrm{Cr}$, Mo e $\mathrm{Cu}$ em solução sólida e também a influência da austenita retida entre os grãos de ferrita acicular, que são maiores e mais grosseiros nos metais 1 e 2 (maior aporte).

Nos metais de solda 7 e 8 o efeito benéfico da ferrita acicular na tenacidade deve se sobrepor ao efeito nocivo da austenita retida implicando em uma menor temperatura de transição.

Nos metais como soldados elaborados com o eletrodo EM-12K (de menor temperabilidade) 3, 4, 5 e 6, a temperatura de transição AFTT é menor nos cordões 5 e 6 de menor aporte que teve maior 
velocidade de resfriamento e maior quantidade de ferrita acicular além de uma menor quantidade de microfase.

Comparando-se os cordões como soldados com mesmo aporte de calor, com eletrodos diferentes, observa-se que nos cordões 1 , 2,3 e 4 de maiores aportes (menores velocidades de resfriamento) a temperatura de transição dos cordões 3 e 4 , elaborados com eletrodo EM-12K (de menor temperabilidade) é maior que dos cordões 1 e 2 elaborados com eletrodo EB-2 (de maior temperabilidade), provavelmente devido a influência da austenita retida.

Para os cordões $5,6,7$ e 8 , de menores aportes de calor (maiores velocidades de resfriamento) as temperaturas de transição AFTT dos cordões 7 e 8 elaborados com eletrodo EB-2 (maior temperabilidade) são menores que as dos cordões 5 e 6 elaborados com eletrodo EM-12K (menor temperabilidade), devido ao balanceamento da composição química, teor de ferrita acicular e influência da austenita retida.

\section{$6.5 .5-\underline{\text { CTOD }}$}

$\mathrm{Na}$ tabela 5.8 que apresenta os resultados do ensaio de CTOD , pode-se observar que o cordão 7P1, que apresentou um teor de austenita retida maior, $10 \%$, apresentou um $\delta$ menor, $0,22 \mathrm{~mm}$, enquanto $\circ$ cordão $5 \mathrm{P} 1$ apresentou um teor de austenita retida de $4 \%$ e um $\delta$ de $0,33 \%$, - que vem comprovar a influência do teor de austenita retida nessa propriedade.

Um requisito básico de tenacidade à fratura mencionado em vários trabalhos é o CTOD de no mínimo $0,20 \mathrm{~mm}$ a $-10^{\circ} \mathrm{C}$, segundo KOBAYASHI (1995). Considerando esse CTOD de 0,20 mm como sendo de carga máxima , o cordão 5P1 estaria no limite mínimo enquanto o cordão 7P1 estaria acima da especificação, lembrando que os dois cordões, após 
o tratamento térmico de alívio de tensões, tiveram o teor de austenita retida reduzido a zero.

Observou-se que o resultado de CTOD não concorda com o ensaio Charpy, onde o cordão 7P1 apresentou uma temperatura de transição AFTT de $-44^{\circ} \mathrm{C}$ enquanto o cordão $5 \mathrm{P} 1$ apresentou uma AFTT de $-21^{\circ} \mathrm{C}$. Porém, segundo KOBAYASHI (1995) a situação com respeito a tenacidade do ensaio CTOD não é a mesma do ensaio Charpy, o primeiro é relativo somente ao início da trinca, enquanto no segundo a tenacidade ao impacto é também uma função da energia de propagação da trinca.

\subsection{5 - Tratamento Térmico Pós-Soldagem}

\subsubsection{1 - Microfase}

O tratamento térmico pós-soldagem possibilitou a decomposição da austenita retida em ferrita, como descrito por EVANS $(1985,1986)$. Pela tabela 5.7 e pelas micrografias pode-se observar que houve redução na sua quantidade em todos os cordőes de solda após o tratamento térmico.

Para os cordões obtidos a partir do fluxo BX-200, que apresentaram maior teor de austenita retida, a redução após o tratamento foi de $89 \%$ em média, sendo que para o cordão 7 a redução foi de $100 \%$, ou seja, conseguiu-se eliminar totalmente a austenita retida. Para os cordões obtidos a partir do fluxo OK-1071 a redução foi de $87,5 \%$ em média, sendo que para o cordão 5 a redução foi de $100 \%$. Os dois cordões onde se obteve a redução de $100 \%$ foram obtidos com menor aporte de calor. Para os cordões obtidos a partir do eletrodo EB-2 a média de redução foi de $92 \%$, e para os cordões elaborados com eletrodo EM-12K a redução média foi de $84 \%$. 


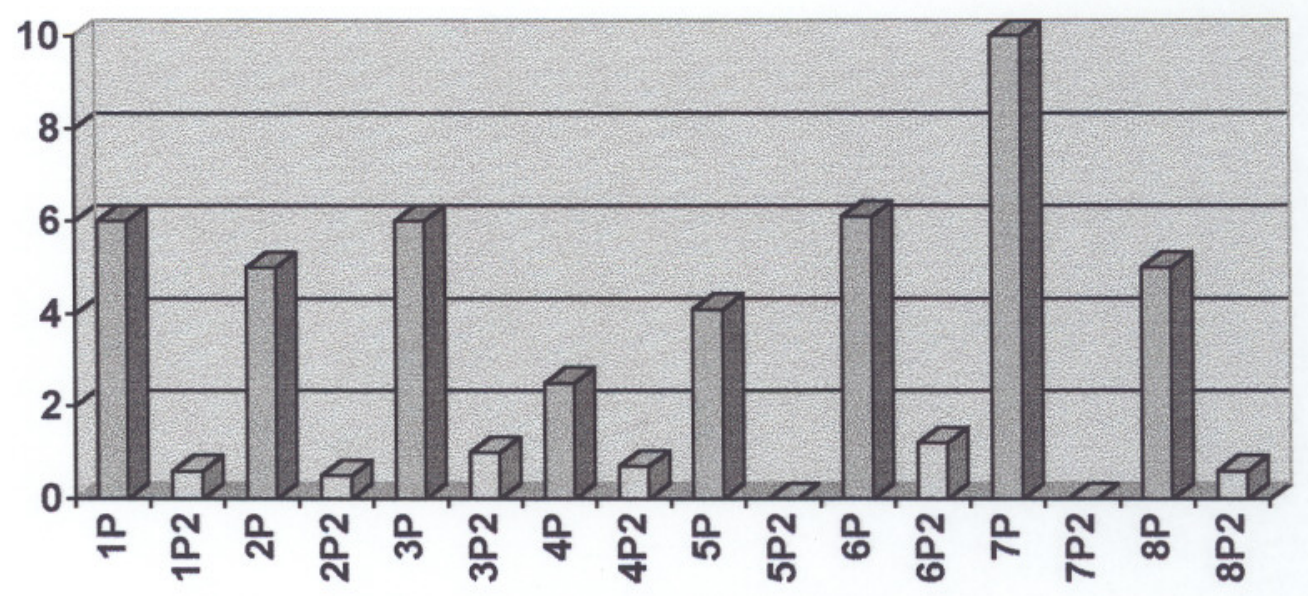

FIGURA 6.9 - \% Austenita Retida (os cordoes com índice 2 foram tratados termicamente)

\subsubsection{2 - Dureza}

Após o alívio de tensões nota-se que houve aumento nos valores de dureza para todos os cordões, com exceção dos cordões 5,7e 8.

De acordo com NOVAES GOMES et al. (1993) após o alívio de tensões nos metais de solda de alta temperabilidade a dureza aumenta enquanto nos de baixa temperabilidade houve uma redução nos valores das medidas de dureza.

$\mathrm{Na}$ tabela 5.3 nota-se que, entre os cordões elaborados com o eletrodo EB-2 (maior temperabilidade),1,2,7e8, aqueles feitos com maior aporte de calor, $1 \mathrm{e} 2$,tiveram a dureza aumentada, porém aqueles feitos com menor aporte , 7 e 8, tiveram uma leve diminuição no seu valor de dureza.

Tal comportamento deve-se, provavelmente, à diferença de composição química dos cordões deste trabalho em relação ao trabalho citado de NOVAES GOMES et al. (1993) decorrente da variação de fluxo entre os trabalhos. Os cordões 7 e 8 apresentam um menor teor de $\mathrm{C} \mathrm{e} \mathrm{Cr}$ e um maior teor de $\mathrm{Mn}$, além do fato de que o cordão 7 teve a austenita retida eliminada. Deve-se notar também que no caso dos cordões 7 e 8 a diminuição na dureza foi de $2 \%$ para o cordão 7 e $1 \%$ para o cordão 8 , $\circ$ 
que não caracteriza uma reversão no comportamento descrito no trabalho de NOVAES GOMES et al.(1993) .

Nos cordões elaborados com eletrodo EM-12K (menor temperabilidade) onde esperava-se queda na dureza após tratamento térmico (de acordo com NOVAES GOMES et al. (1993), observou-se um aumento, com exceção do cordão 5 (que teve a austenita retida eliminada), onde houve diminuição no valor da dureza. Observando-se as composições químicas em relação ao trabalho de NOVAES GOMES et al. (1993), como no caso anterior, neste trabalho os cordões apresentaram teores menores de $\mathrm{C}$ e $\mathrm{Cr}$ e maiores teores de $\mathrm{Mn}$.

Segundo ainda NOVAES GOMES et al. (1993) o aumento nos valores de dureza foi atribuído à sobreposição do efeito do endurecimento por solução sólida com o elemento $\mathrm{Cr}$, oriundo de uma possível decomposição de carbonetos, em relação ao efeito da acomodação do reticulado causado pelo alívio das tensões residuais.

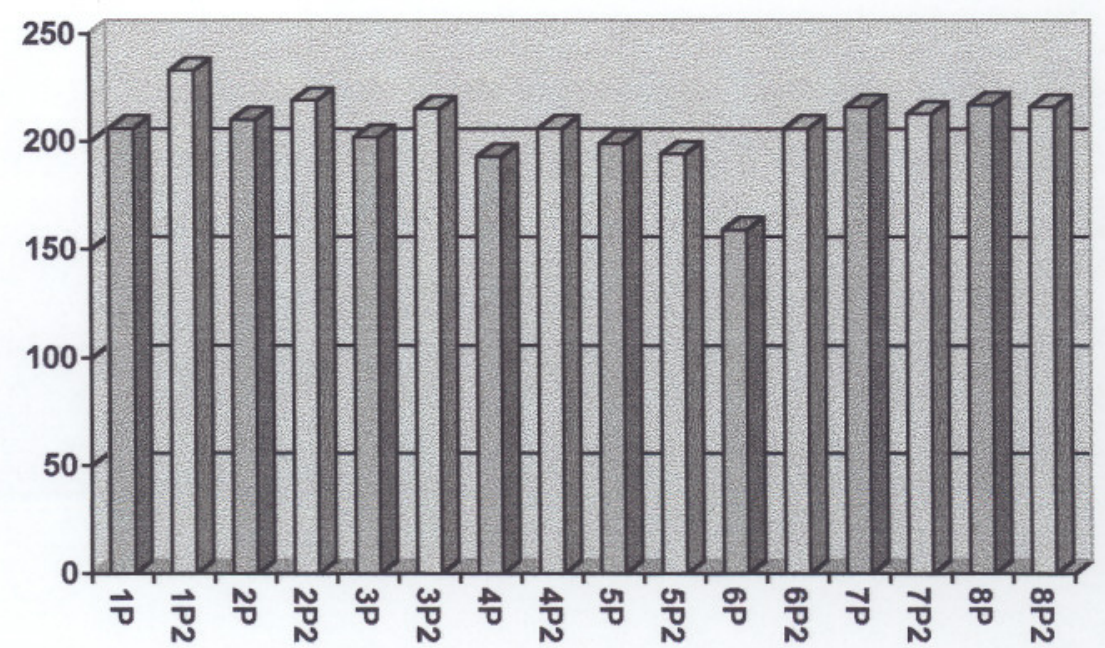

FIGURA 6.10 - Dureza HV (os cordões de índice 2 foram tratados termicamente) 


\subsubsection{3 - Tracão}

Após o alívio de tensões, houve aumento do limite de escoamento e da ductilidade em todos os cordões de solda, com exceção do cordão 5 (EM-12K , OK-1071, menor aporte), que teve o limite de escoamento praticamente igual, antes e depois do tratamento térmico (diferença de 0,5\%).

$O$ alivio de tensões, além de permitir melhor acomodação do reticulado cristalino, promove a esferoidização dos carbetos, o que vai implicar em difusão do $\mathrm{Cr}$ para a matriz , resultando num endurecimento por solução sólida. Houve também redução da austenita retida implicando numa melhoria das propriedades mecânicas, segundo ENTREKIN (1987).

Pela figura 6.8 observa-se que os cordões de solda 1, 2, 7 e 8, elaborados com eletrodo EB-2 e portanto de maior temperabilidade e com maior quantidade de ferrita acicular, apresentaram maior limite de escoamento que os cordões elaborados com eletrodo EM-12K de microestrutura mais grosseira, o que é coerente com o modelo de DOLBY, de acordo com DOLBY (1979), que sugere que a resistência e a tenacidade ao impacto dos metais de solda estão relacionados com o teor de ferrita acicular.

A presença de austenita retida na microestrutura influenciou nas propriedades mecânicas e observa-se que, após o alívio de tensões, com a redução ocorrida na austenita retida e também pela esferoidização dos carbetos, houve aumento no limite de escoamento dos cordões de solda. 


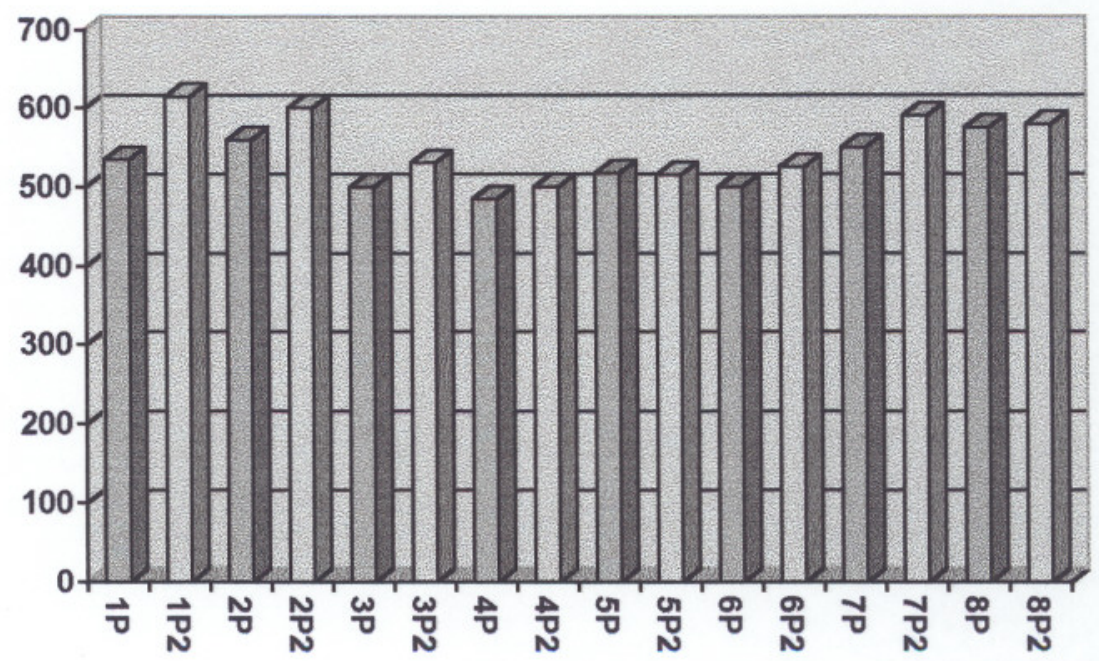

FIGURA 6.11 - Limite de Escoamento [Mpa] (os cordões de índice 2 foram tratados termicamente)

\subsubsection{4 - Impacto}

TABELA 6.2 - Resultados do ensaio de impacto Charpy após o tratamento térmico de alívio de tensões

\begin{tabular}{|c|c|c|c|c|c|c|c|c|}
\hline & $1 \mathrm{P} 2$ & $2 \mathrm{P} 2$ & $3 \mathrm{P} 2$ & $4 \mathrm{P} 2$ & $5 \mathrm{P} 2$ & $6 \mathrm{P} 2$ & $7 \mathrm{P} 2$ & $8 \mathrm{P} 2$ \\
\hline AFTT $\left({ }^{\circ} \mathrm{C}\right)$ & -12 & -18 & -5 & -14 & -23 & -18 & -20 & -19 \\
\hline Patamar(J) & 116 & 123 & 136 & 147 & 130 & 146 & 153 & 105 \\
\hline $28 \mathrm{~J}\left({ }^{\circ} \mathrm{C}\right)$ & -39 & -39 & -25 & -64 & -45 & -39 & -42 & -33 \\
\hline
\end{tabular}

Observa-se que para os cordões elaborados com eletrodo EM-12K (3, 4, 5 e 6) houve redução na temperatura AFTT após o alívio de tensões, segundo ENTREKIN (1983), devido a esferoidização dos carbetos, a redução das tensões internas no reticulado cristalino e a decomposição das microfases promovendo aumento na tenacidade.

Contudo, para os cordões elaborados com eletrodo EB-2, houve aumento nas temperaturas de transição. No caso dos cordões 1 e 2 , de maior aporte de calor, observou-se que houve aumento na dureza e na 
tensão de escoamento mas a temperatura de transição aumentou. Esses cordões foram os que apresentaram as maiores porcentagens de ferrita acicular e os maiores teores de $\mathrm{Cr}$.

Nos cordões 7 e 8, elaborados também com eletrodo EB-2, mas com menor aporte de calor, houve uma diminuição na dureza e um aumento menos significativo no limite de escoamento, sendo que esses cordões apresentaram também altos níveis de ferrita acicular.

Entre os cordões elaborados com eletrodo EM-12K , observase uma diminuição, embora pequena, na temperatura de transição, o que concorda com ENTREKIN (1983). O cordão 4 (EM-12K, OK-1071, maior aporte) não teve alterada sua temperatura de transição AFTT, mostrando que $\mathrm{o}$ alívio de tensões teve pouca influência nas propriedades mecânicas desse cordão.

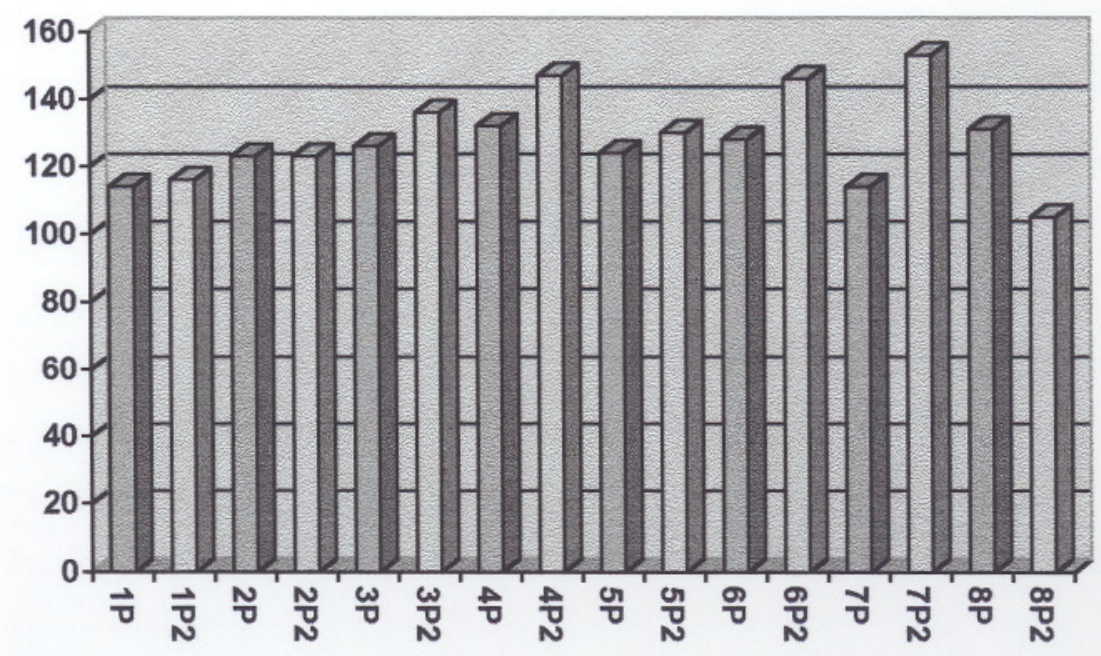

FIGURA 6.12 - Patamar de Energia Dúctil [kJ] (os cordões de índice 2 foram tratados termicamente)

Comparando-se os cordões após alívio, elaborados com mesmo eletrodo, com aportes de calor diferentes, nota-se que naqueles elaborados com eletrodo EB-2, de maior temperabilidade, após o alívio de tensões a temperatura AFTT dos cordões 7P2 e 8P2 de menor aporte, é pouco menor que dos cordões 1P2 e $2 \mathrm{P} 2$, de maior aporte. A quantidade de ferrita acicular dos cordões 7P2 e 8P2 é menor que dos cordões 1P2 e 
$2 \mathrm{P} 2$, porém a quantidade de microfase é maior e mais grosseira em 1P2 e $2 \mathrm{P} 2$, implicando numa menor tenacidade ao impacto.

Nos cordões elaborados com mesmo aporte de calor, verificase que entre aqueles feitos com maior aporte a temperatura de transição para os cordões obtidos com e eletrodo EB-2 (maior temperabilidade), 1P2 e $2 \mathrm{P} 2$, é pouco menor que os obtidos do eletrodo EM-12K (menor temperabilidade), 3P2 e 4P2. A quantidade de ferrita acicular nos cordões 1P2 e 2P2 é maior que dos cordões 3P2 e 4P2 e houve decomposição da austenita retida favorecendo a tenacidade.

Já nos cordões de solda de menor aporte, a tenacidade dos metais de solda elaborados com EM-12K (menor temperabilidade) , 5P2 e 6P2, é maior que a dos cordões elaborados com EB-2 (maior temperabilidade), 7P2 e 8P2. Isto pode ser devido a melhor acomodação do reticulado cristalino no alívio de tensões e ainda uma menor ocorrência de austenita retida para a composição do cordão $5 \mathrm{P} 2$, implicando numa tenacidade superior aos cordões 7P2 e 8P2, de acordo com ENTREKIN (1983). 


\section{7 - CONCLUSÕES}

1. Os aportes de calor utilizados promoveram diluição suficiente, de modo a se obter uma composição química balanceada.

2. Os fluxos escolhidos promoveram a variação na composição química, em relação aos trabalhos anteriores, como esperado.

3. Os teores de ferrita acicular são adequados para garantir boas propriedades mecânicas.

4. Os cordões elaborados com eletrodo EB-2 apresentaram maiores teores de ferrita acicular em relação aqueles com EM-12K.

5. A variação nos fluxos, com conseqüente variação na composição química, garantiu uma menor quantidade de microfase em relação aos trabalhos anteriores.

6. De acordo com a análise metalográfica e morfológica, a microfase foi identificada como austenita retida.

7. A mudança de fluxo de BX-200 para OK-1071, provocou uma diminuição na porcentagem de austenita retida como conseqüência dos teores de $\mathrm{C}$.

8. Os cordōes elaborados com EB-2 apresentaram uma dureza maior em relação àqueles com EM-12K em função dos menores teores de ferrita acicular e elementos de liga.

9. Os cordões elaborados com EB-2 apresentaram um limite de escoamento maior em relação àqueles com EM-12K

10. Os cordões que apresentaram um maior teor de austenita retida apresentaram um patamar de energia dúctil mais baixo que 0 esperado pelo teor de oxigênio. 
11. O cordão com maior teor de austenita retida apresentou um CTOD menor, mostrando a forte influência dessa fase sobre a tenacidade.

12. O tratamento térmico mostrou-se eficaz na decomposição da austenita retida.

13. Essa redução no teor de austenita retida refletiu-se positivamente em todas as propriedades mecânicas.

\section{SUGESTÕES PARA TRABALHOS FUTUROS}

- realização de ensaios sub-zero para simulação de condições de serviço

- realização de fratografias para melhor identificação do caminho das trincas e melhor entendimento do mecanismo de fragilização da austenita retida - realização de ensaios de CTOD em amostras de todas as combinações 


\section{8 - BIBLIOGRAFIA}

AARONSON, H. I. ; REYNOLDS, Jr. W. T. ; SHIFLET, G. J. ; SPANOS, G. (1990) Bainite viewed three diferents ways. Metallurgical transactions A, v. 21A, p.1343-80, Jun.

ABSON, D. J. (1989) Non-metallic inclusions in ferritic steel weld metals - a review. Welding in the World, v. 27, n.314, p.76-101. Mar.IApr.

ABSON, D. J. ; PARGETER, R. J. (1986) Factors influencing as-deposited strenght, microstructure, and toughness of manual metal arc welds suitable for C-Mn steel fabrications. International Metals Reviews, v. 31, n.4, p.141-94.

AKSELSEN, O. M. ; SIMONSEN, T. (1987) Techniques for examining transformation behaviour in weld metal and HAZ. Welding in the World, v. 25, n. $1 / 2$, p.26-34.

ALÉ, R. M. ; JORGE, J. C. F. ; REBELLO, J. M. A. (1993 (a)) Constituintes microestruturais de soldas de aços $\mathrm{C}-\mathrm{Mn}$ baixa liga. Parte l: conceitos básicos. Soldagem e Materais, v. 5, n.2, Arquivo Técnico, Abr.JJun.

ALÉ, R. M. ; JORGE, J. C. F. ; REBELLO, J. M. A. (1993 (b)) Constituintes microestruturais de soldas de aços C-Mn baixa liga. Parte II: metal de solda. Soldagem e Materiais, v.5, n.3, Arquivo Técnico, Jul./Set.

BAILEY, N. (1991) Submerged arc welding ferritic steels with alloyed metal powder. Welding Journal, v.70, n.8, p.187s-206s, Aug.

BHADESHIA, H. K. D. H. ; CHRISTIAN, J. W. (1990) Bainite in steels. Metallurgícal Transaction A, v.21 A, p.767-797, Apr.

BHADESHIA, H. K. D. H. ; EDMONDS, D. V. (1979) The bainjte transformation in a silicon steel. Metallurgical transactions A, v.10A, p.895-907, Jul.

BHADESHIA, H. K. D. H. ; EDMONDS, D. V. (1980) The mechanism of bainite formation in steels. Acta Metallurgica, v. 28, p.1265-73. 
BHADESHIA, H. K. D. H. ; SVENSSON, L-E. (1993) Modelling of ev.olution of microstructure in steel weld metal. Mathematical Modelling of Weld Phenomena. Ed. Cerjak, H. and Easterling, K. E. THE INSTITUTE OF MATERIALS, London, p.109-180.

BHADESHIA, H. K. D. H. ; SVENSSON, L-E. ; GRETOFT, B. (1985) A model for the development of microstructure in low-alloy steel ( $\mathrm{Fe}-\mathrm{MnSiC})$ wels deposits. Acta Metallurgica, v.33. n.7, p.1271-83.

BHADESHIA, H. K. D. H. ; SVENSSON, L-E. ; GRETOFT, B. (1986) The austenita grain structure of low-alloy steel weld deposits. Journal of Materials Science, v.21, n.11, p.3947-51, Nov.

BISCHOFF, R. ; MACHADO, I. G. (1989) Propriedades mecânico/metalúrgicas do metal de solda depositado por arco submerso com adição de pó de ferro. In: ENCONTRO NACIONAL DE TECNOLOGIA DE SOLDAGEM, 15., São Paulo, 1989. Anais. São Paulo, ABS, v.2, p.585-601.

BOLD, T. ; GARBARZ, B. (1980) The structure of martensite-austenite islands in granular bainite. Practical Metallography, v.17, p.338-43.

BRAMFITT, B. L. ; SPEER, J.G. (1990) A prespective on the morpholo $\square y$ of bainite. Metallurgical transactions A, v.21 A, p.817-29, Apr.

CAMPBELL, H. C. ; JOHNSON, W. C. (1967) Granular metal filler metals for arc welding. Welding Journal, v.46, n.3, p.200-6, Mar.

COCHRANE, R. C. (1983) Weld metal microstructures: a sttate of the art review. Welding in the World, v.21, n.1/2, p.16-24, Jan./Feb.

COSTA, H. R. ; BOTT, I. S. ; OURO, C. R. (1995) Avaliação do efeito de múltiplos tratamentos térmicos de alívio de tensões na microestrutura e propriedades mecãnicas de um metal de solda ferrítico. Metalurgia e Materiais, v.51, n.442, p.536-540, Jun.

COURT, S. A. ; POLLARD,G. (1987) The development of microstructure in CMn steel weld deposits. Welding Metallurgy of Structural Steels. Ed. Koo, J. Y. THE METALLURGICAL SOCIETY, Denver, p.505-517. 
DAVID, S. A. ; VITEK. J. M. (1989) Correlation between solidification parameters and weld microstructures. International Materials Reviewsv.34, n.5, p.313-45.

DAVIES, G. J. ; GARLAND J. G. (1975) Solidification structures and ,properties of fusion welds. International Metallur ical Reviews, v.20, n.2, p. 83-106.

DOC. IIW-9gg-gg (1gg1) INTERNATIONAL INSTITUTE OF WELDING.

Guide to the light microscope examination of ferritic steel weld metals. Welding in the World, v.29, n.7/8, p.160-76.

DOLBY, R. E. (1979) Factors controlling HAZ and weld metal toughness in CMn steels. In: ENGINEERING APLICATIONS OF FRACTURE ANALYSIS, South Africa, Nov. 1979. Proceedings of Fracture' 79. Pergamon Press, p.117-34.

ELLIS, D. J. (1990) Submerged-arc welding - An update. Welding and Metal Fabrication, v.58, n.9, p.434-436, Oct.

ES-SOUNI, M. ; BEAVEN, P. A. ; EVANS, G. M. (1991) Microstructure and mechanical properties of $\mathrm{Cu}$-bearing shielded metal arc $\mathrm{C}$-Mn weld metal. Welding Journal, v.70, n.3, p.80s-90s, Mar.

EVANS, G. M. (1980) The effect of manganese on the microstructure and properties of C-Mn all-weld metals deposits. Welding Journal, v.59, n.3, p.67s-75s, Mar.

EVANS, G. M. (1982) The effect of heat input on the microstructure and properties of C-Mn all-weld-metal deposits. Welding Journal, v.61, n.4, p.125s-132s, Apr.

EVANS, G. M. (1983) The effect of carbon on the microstructure and properties of C-Mn all-weld metals deposits. Welding Journal, v.62, n.11, p.313s-320s, Nov.

EVANS, G. M. (1985) The effect of heat treatment on the microstructure and properties of C-Mn all weld metal deposits. Metal Construction, v.17, n. 10, p.676R-682R, Oct.

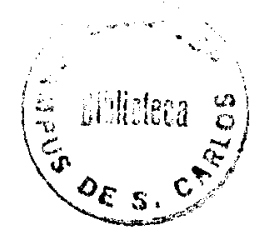


EVANS, G. M. (1986 (a)) The effect of silicon on the microstructure and properties of C-Mn áll-weld metals deposits. Metal Construction, v.18, n.7, p.438R-44R, Jul.

EVANS, G. M. (1986 (b)) The effect of stress-relieving on the microstructure and properties of C-Mn all-weld metal deposits. Welding Journal,'v. 65 n.12 p.326s-334s, Déc.

EVANS, G. M. (1988) The effect of molybdenum on the microstructure and properties of C-Mn all-weld metals deposits. Joining et Materials, v.1, n.5, p.239-46, Nov.

EVANS, G. M. (1989) The effect of chromium on the microstructure and properties of C-Mn all-weld metals deposits. We/ding and Metal Fabrication, v.57, n.7, p.346-58, Aug./Sept.

EVANS, G. M. (1990) The effect of nickel on the microstructure and properties of C-Mn all-weld metals deposits. Oerlinkon-Scwei $\square 3$ mitt, v.48, p.18-35. Aug./Sept.

FARRAR, R. A. ; HARRISON, P. L. (1987) Acicular ferrite in carbonmanganese weld metals: an overview. Journal of Materials Science, v. 22, n.11, p.3812-20.

FLECK, N. A. ; GRONG, O. ; EDWARDS, G. R. ; MATLOCK, D. K.(1986) The role of filler metal wire and flux composition in submerged arc weld metal transformation kinetics. Welding Journal, v. 65, n.5, p.113s-121 s May.

FRASER, R. ; MCLEAN, A. ; WEBSTER, D. J. ; TAYLOR, D. S. (1982) High deposition rate submerged-arc welding for critical application. In: INTERNATIONAL CONFERENCE ON OFFSHORE WELD $\square D$ STRUCTURES, 2., London,1982. Proceedings. London, paper 12, p.115. 
GLOVER, A. G. ; McGRATH, J. T. ; TINKLER, M. J. ; WEATHERLY, G. C. (1977) The influencé of cooling rate and composition on weld metal microstructures in a C/Mn and a HSLA steel. Welding Journal, v.56, n.9, p.267s-273s, Sept.

GONÇALVES, G. M. B. G. (1991) Estudo comparativo da ZTA de um aço ARBL soldado pelo processo a arco submerso com e sem adição de pó de ferro. São Carlos, SP,1995,1 OOp. Dissertação (Mestrado) - Escola de Engenharia de São Carlos, Universidade de S9o Paulo.

GRONG, O. (1994) Metallurgical modeling of welding. THE INSTITUTE OF MATERIALS. London.

GRONG, O. ; MATLOCK, D. K. (1986) Microstructural development in mild and low-alloy steel weld metals. Internationa/ Metals Reviews, v.31, n.1, p. 27-48, Jan.

HANZAKI, A. Z. ; HODGSON, P. D. ; YUE, S. (1997) Retained austenite characteristics in thermomechanically processed Si-Mn transformation induced plasticity steels. Metallurgical and Materials Transactions A, v.28A, p. 2405-14, Nov.

HARRISON, P. L. (1979) Continuous cooling transformation (CCT) diagrams for niobium bearing weld metals. An Interim Report. University of Southampton - Engineering Materials Laboratories. Mar.

HARRISON, P. L. ; FARRAR, R. (1987) Microstructural development and toughness of C-Mn and C-Mn-Ni weld metals. Part 1 - Microstructural development. Metal Construction, v.19, n.7, p.392R-399R, Jul.

HARRISON, P. L. ; FARRAR, R. (1989) Application of continuous cooling transformation diagrams for welding of steels. Internationa/ Materials Reviews, v.34, n.1, p.35-51.

HEHEMANN, R. F. ; KINSMAN, K. R. ; AARONSON, H. I. (1972) A debate on the bainite reaction. Metallurgical transactions, v. 3, p.1077-94, May. 
HOEKSTRA, S. ; MUNNIG SCHMIDT-VAN DER BURG, M. A. ; DEN OUDEN, G. (1986j Microstructure and notch thoughness of ferritic weld metal. Metal Construction, v.18, n.12, p.771-5, Dec.

HOEKSTRA, S. ; MUNNIG SCHMIDT-VAN DER BURG, M. A. ; DEN OUDEN, G. (1985) Influence of microstruture on mechanical properties of two single-bead ferritic weld metals. Welding Journal Research Supplement, v.63, n.3, p.63s-70s, Mar.

HONEYCOMBE, R. W. K. (1985) Aços: microestrutura e propriedades. Lisboa, Fundação Calouste Gulbenkian.

HORII, Y. ; OHKITA, S. ; WAKABAYASHI, M. ; NAMURA, M. (1988) Study on the toughness of large-heat input weld metal for low temperature service TMCP steel. Nippon Steel Technical Report nQ 32, Nipppn Steel Welding and Engineeríng Co. Apr.

HORSFIELD, A. M. (1978) The fundamental principles of submerged arc weld. In: The Welding Institute. Submerged arc welding. Cambridge, 1978. cap.1, p.2-8.

HRIVNAK, I. ; MATSUDA, F. ; IKEUCHI, K. (1992) Investigation of M-A constituent in high strength steel welds. Transactions of JWRJ, v. 21 , n.2, p.9-13.

JARMAN, R. A. ; HENRY, G. ; JUDSON, P. (1978) The effect of intercritical heat treatment on the CVN toughness of mild steel weld metal. Welding and Metal Fabrication, v.53, n.9, p.299-302, Oct.

JOARDER, A. ; SAHA, S. C. ; GHOSE, A. K. (1992) Study of submerged arc weld metal and heat-affected zone microstructure of a plain carbon steel. Journal of Welding Research. Ed. Weber, J. D. American Welding Society, Miami, p.141 s-146s.

JORGE, J. C. F. ; REBELLO, J. M. A. (1989) Microscopia eletrônica de varredura de cordões de solda de aços de alta resistência. Soldagem e Materiais, v.1, n.3, p.44-49, Jul./Set. 
KENNY, B. G. ; KERR, H. W. ; LAZOR, R. B. ; GRAVILLE, B. (1985) Ferrite transformation charácteristics and Cct diagrams in weld metals. Metal Construction, v.17, n.6, p.374R-381 R, Jun.

KOBAYASHI, Y. (1995) Efeito da adição controlada de pó metálico nas propriedades microestruturais e mecânicas no metal depositado por arco submerso em aço ARBL. São Carlos, SP, 1995, 125p. Tese (Doutorado) Escola de Engenharia de São Carlos, Universidade de São Paulo.

KOBAYASHI, Y. ; NOVAES GOMES, S. I. ; SPINELLI, D. (1995) Influência das microfases na tenacidade de metais depositados por arco submerso com adição de pó metálico. Metalurgia e Materiais, v.51, n.442, Jun.

KONING, A. C. (1985) Dvelopments in materials and welding thecnology for offshore structures. Metal Construction, v.17, n.11, Nov.

KONKOL, P. J. (1988) Effects of long-time postweld heat treatment on the properties of constructional-steel weldments. WRC Blletin 330, Jan.

LIAO, F-C. ; LIU, S. (1992) Effect of deoxidation sequence on carbon manganese steel weld metal microstructures. Welding Joumal, v.71, n.3, p.94s-103s, f $\square$ lar.

LIU, S. ; OLSON, D.L. (1986) The role of inclusion in controlling HSLA steel weld microstructure. Welding Journal, v. 65, n.6, p.139s-49s, Jan.

LIU, S. K. ; REYNOLDS, W. T. ; HU, H. ; SHIFLET, G. J. ; AARONSON, H. I. (1985) Discussion of the "bainite transformation in a silicon steel". Metallurgical transactions A, v.16A, p.457-68, Mar.

MATSUDA, F. ; FUKADA, Y. ; OKADA, H. ; SHIGA, C. ; IKEUCHI, K. ; HORII, Y. ; SHIWAKU, T. ; SUZUKI, S. (1996) Review of mechanical and metallurgical investigations of martensite-austenite constituent in welded joints in Japan. Welding in the World, v.37, n.3, p.134-154.

NOVAES GOMES, S. I. (1985) Influência do Mn e Nb na microestrutura e nas propriedades dé tração e impacto de metais de solda obtidos por arco submerso em aço ARBL. São Carlos, 1985. 236p. Tese (Doutorado) Escola de Engenharia de São Carlos, Universidade de São Paulo. 
NOVAES GOMES, S. I. ; SANT'ANNA, P. C. ; KOBAYASHI, Y. (1993) Efeito do tratamento térmico de alívio de tensões na tenacidade ao impacto de metais de depositados por arco submerso com adição de pó metálico. In: ENCONTRO NACIONAL DE TECNOLOGIA DE SOLDAGEM, 19. Águas de São Pedro, 1993. Anais. Águas de São Pedro, ABS, v.1, p.111-126.

OLDLAND, P. T. ; RAMSAY, C. W. ; MATLOCK, D. K. ; OLSON, D. L. (1989) Significant features of high-strength steel weld metal microstructures. Welding Journal, v.68, n.4, p.158s-168s, Apr.

PICKERING, G. B. (1987) Physical metallurgy and the design of steels. London, Applied Science.

PORTER, D. A. ; EASTERLING, K. E. (1981) Phase transformation in metals and alloys. Van Nostrand Reinhold Company, New York. PORTER, L. F. ; REPAS, P. E. (1982) The evolution of HSLA steel. Joumal of Metals, v.34, n.4, p.14-21.

RAITER, V. ; GONZALEZ, J. C. (1989) Influence of molybdenum on the microstructure and properties of weld with different manganese contents. Canadian Metallurgical Quarterly, v.28, n.2, p.179-8525, Fロb.

REYNOLDS, G. H. ; KACHELMEIR, E. J. (1978) Adding powdered metal filler speeds deposition rate. Metal Construction, v.10, n.9, p.427- $\square 0$.

RICKS, R. A. ; HOWELL, P. R. ; BARRITE, G. S. (1982). The nature of acicular ferrite in HSLA steel weld metals. Joumal of Materials Science, v. 17, n.3, p.732-40, Mar.

RODGES, K. J. ; LOCHHEAD. J. C. (1987) Submerged arc welding metal powder additions, productivity and properties. Welding Journal, v.66, n.10, p.21-27, Oct.

RODRIGUES, P. E. L. B. ; ROGERSON, J. H. (1980) How weld metal thermal cycles determine the toughness of submerged arc welds. Welding and Metal Fabrication, v. 48, n.3, p.183-93, Apr. 
SHILICK, R. (1987) Investigação nas propriedades mecânicas de metal de solda depositado por arco submerso com adição de pó-de-ferro. In: REUNIÃO INTERMEDIÁRIA DAS COMISSŐES TÉCNICAS DO IIW, Rio de Janeiro,1987, p.589-607, Nov.

SNIEDER, G. ; KERR, H. W. (1984) Effects of chromium additions and flux type on the structure and properties of HSLA steel submerged arc weld metal. Canadian Metallurgical Quarterly, v.23, n.3, p.315-25, Mar.

SOUZA, P. C. R. D. (1991) Efeito da adição do pó de ferro sobre a microestrutura, composição química e propriedades mecânicas em soldas a arco submerso. São Carlos, SP,1991,131 p. Dissertação (Mestrado)Escola de Engenharia de São Carlos, Universidade de São Paulo.

STOUT, R. D. ; (1985) Postweld heat treatment of pressure vessel steels. WRC Bulletin 302, Feb.

SUGDEN, A. A. B. ; BHADESHIA, H. K. D. H. (1988) A model for the strength of the as-deposited regions of steel weld metals. Metallurgical Transactions A, v.19A, p.1597-1602, Jun.

SUGDEN, A. A. B. ; BHADESHIA, H. K. D. H. (1989) Lower acicular ferrite. Metallurgical Transactions A, v. 20A, n. 9, p.1811-18, S $\square$ p.

SVENSSON, L-E. (1994) Control of microstructures and properties in steel arc welds. Boca Raton, CRC Press.

SVENSSON, L-E. ; GRETOFT, B. (1984) Microstructure and impact toughness of C-Mn weld metals. Welding Journal, v.69, n.12, p.315-25, Mar.

SVENSSON, L-E. ; GRETOFT, B. ; BHADESHIA, H. K. D. H. (1986) An analysis of cooling curves from the fusion zone of steel weld deposits. Scandinavian Journal of Metallurgy, n.15, p.97-103.

TAYLOR, L. G. ; FARRAR, R. A. (1975)Metallurgival aspects of the mechanical properties of submerged-arc weld metal. Welding and Metal Fabrication, v.43, n.4, p.305-10, May. 
TOHRNTON, C. E. (1986) Investigation of the influence of iron powder feed rate on bead on plate welds. Tchnical Report 32. Oerlikon Welding, 6p.

TROYER, W. ; MIKURAK, J. (1974) High deposition submerged arc welding with iron powder joint-fill. Welding Journal, v.53, n.8, p.494-504, Aug.

VILPAS, M. ; NIES, H. ; KREBS, H. ; KARPPI, R. (1990) Mechanical properties of submerged arc welds with metal powder addition. Research Reports 684. Technical Research Center of Filand. Espov. , p.1-40, May. YANG, L. J. ; CHANDEL, R. S. ; BIBBY, M. J. (1993) The effects of process variable on the weld deposit area of submerged arc welds. Welding Journal, v.73, n.1, p.11 s-18s, Jan. 